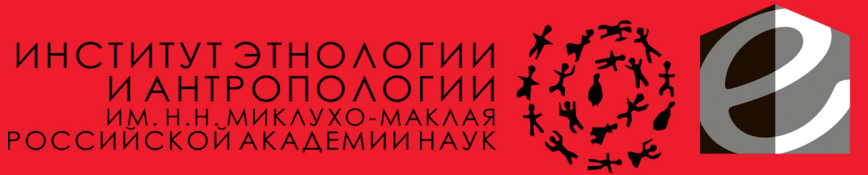

ЕТНОГРАФСКИ ИНСТИТУ

СРПСКЕ АКАДЕМИJЕ
НАУКА И УМЕТНОСТИ
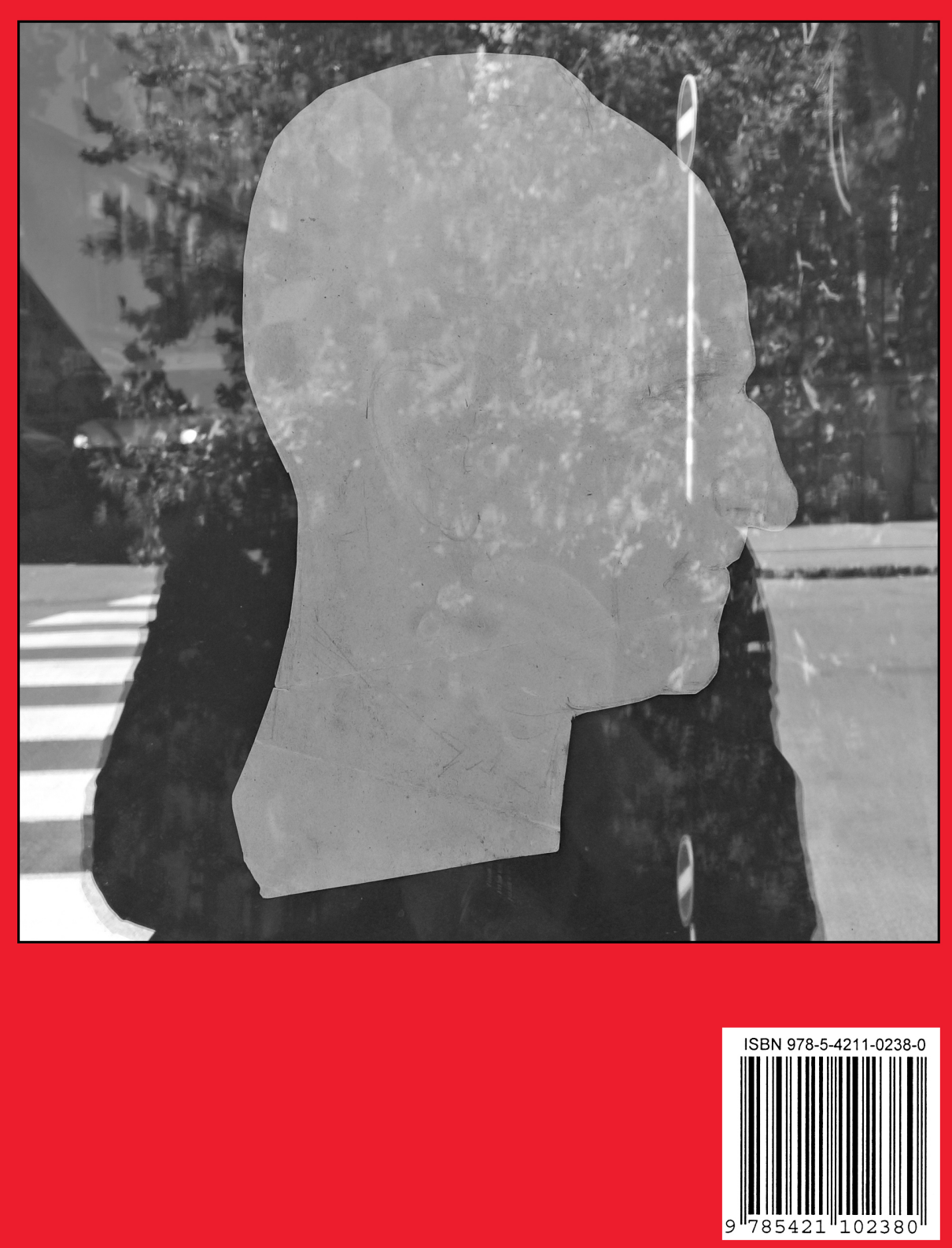

EDITED BY

MARINA MARTYNOVA

IVANA BAŠIĆ

\section{PROSPECTS FOR} ANTHROPOLOGICAL RESEARCH IN SOUTH-PAST PUROPE

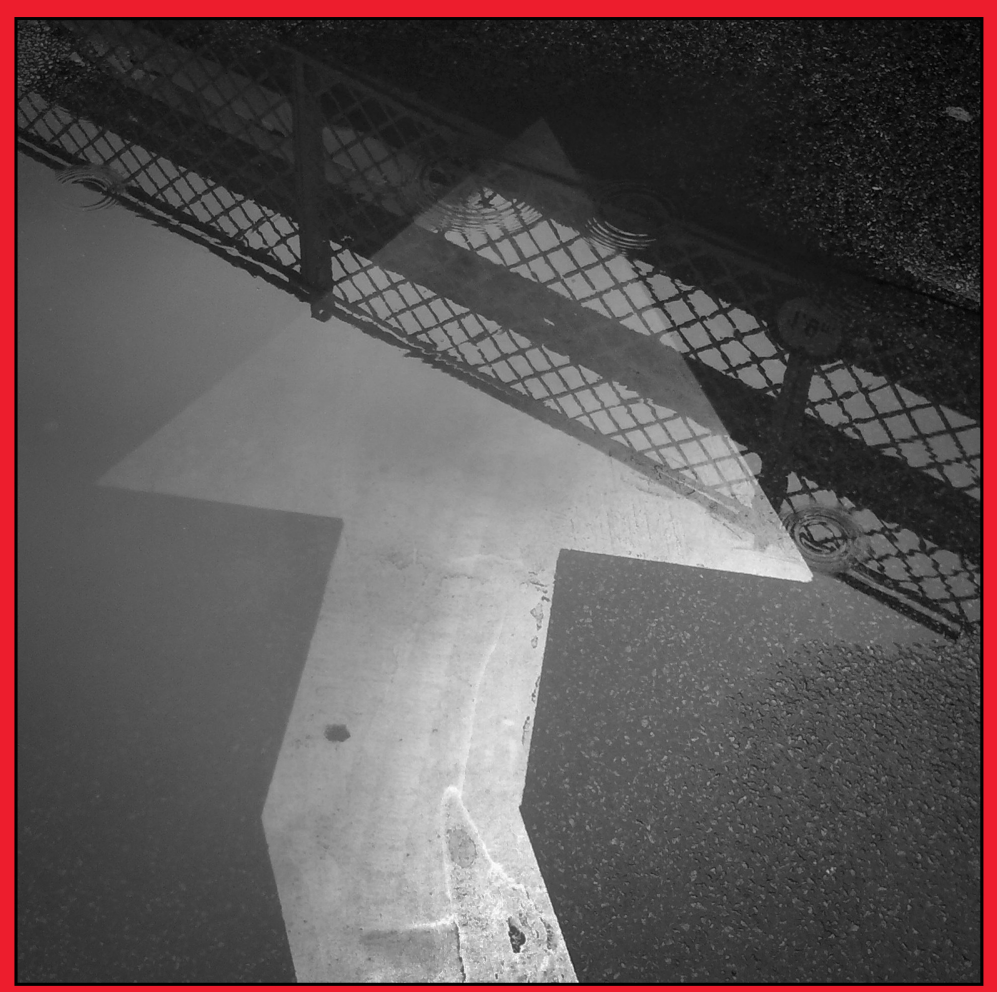


PROSPECTS FOR ANTHROPOLOGICAL RESEARCH IN SOUTH-EAST EUROPE 

N. N. Miklouho-Maklay Institute of Ethnology and Anthropology Russian Academy of Sciences, Moscow, Russia and Institute of Ethnography Serbian Academy of Sciences and Arts, Belgrade, Serbia

\title{
Prospects for Anthropological Research in South-East Europe
}

\author{
Editors \\ Marina Martynova \\ N. N. Miklouho-Maklay Institute of Ethnology \\ and Anthropology Russian Academy of Sciences, \\ Moscow, Russia \\ Ivana Bašić \\ Institute of Ethnography, Serbian Academy of \\ Sciences and Arts, Belgrade, Serbia
}

MOSCOW - BELGRADE 2019 
UDK 39

BBK 63.52

47Querl

Editorial board: Dragana Radojičić (Institute of Ethnography SASA), Srđan Radović (Institute of Ethnography SASA), Natalia Belova (Institute of Ethnology and Anthropology RAS), Marina Martynova (Institute of Ethnology and Anthropology RAS)

The reviewers: Marina Simić (Faculty of Political Sceince, University of Belgrade), Elena Filippova (Institute of Ethnology and anthropology RAS, Moscow, Russia)

\section{PROSPECTS FOR ANTHROPOLOGICAL RESEARCH} IN SOUTH-EAST EUROPE / Ed. Marina Martynova \& Ivana Bašić. - Moscow: IEA RAS \& Belgrade: EI SASA, 2019. - 238 pp.

ISBN 978-542-110-238 0

The book marks a new phase in the fruitful collaboration between the Institute of Ethnology and Anthropology Russian Academy of Sciences and the Institute of Ethnography Serbian Academy of Sciences and Arts. It is an important publication for any future research on the development of ethnology and anthropology in Southeast Europe. The papers presented here, the topics they raise and the methods they employ, comprise an overview of the issues, concepts, phenomena and research methodologies anthropology in this has been dealing with in the early 21st century. Positions of the discipline itself, transformations of traditional culture and various phenomena of contemporary culture in Southeastern Europe are subjected to a theoretical scrutiny in the papers of this volume.

\footnotetext{
(C) Institute of Ethnology and Anthropology, Russian

ISBN 978-542-110-238 0 Academy of Sciences, Moscow, Russia, 2019

(C) Institute of Ethnography, Serbian Academy of Sciences and Arts, Belgrade, Serbia, 2019
} 


\section{CONTENTS}

INTRODUCTION

$7-12$

I. "NETWORKING" AND IDENTITY - CONTEMPORARY ETHNOLOGICAL AND ANTHROPOLOGICAL (SELF)REFLECTION

Ines Prica, Delivery of Ethnographic Material. The Work of Ethnologists in the Conditions of 'Project Interdisciplinarity'

Petko Hristov, Multidimensional Identity and

National Tradition under the Conditions of Pan-

European Mobility. Is Ethnology of a United Europe Possible?

\section{THE NEW CLOTHES OF TRADITIONS}

Milan Tomašević, Anthropological Interpretation of $43-65$ Popular Cosmology: Research Perspectives.

Vesna Petreska, Ritual Kinship in some Calendar Celebrations. A Case Study of the Celebration of $67-88$ Epiphany in Macedonia

Đorđina Trubarac Matić, From the Classical Serbian Epics to The Hague Thematic Circle and 69-113 Back: Decasyllabic Singing as a Linguistic Register Seen from the Functional Perspective

Katerina Petrovska Kuzmanova, Aspects of the Research of the Role of Rusalian Processions in Folk Tradition 
III. (POST)MODERN GAMES AND RITUALS

Aleksandar Krel, Jadranka Đorđević

Crnobrnja, The Celebration of Children's

$135-152$

Birthdays in Belgrade and Consumer Society

Ivan Đorđević, Politics on the Football Field. An

Overview of the Relationship between Ideology

$153-177$ and Sport in Serbia

Ljiljana Gavrilović, MMORPGs and Nationalism

$179-206$

Biljana Anđelković, Some Basic Factors of

$207-229$

Pilgrimage in Contemporary Serbia 


\section{INTRODUCTION}

The edited volume Perspectives of Anthropological Research in South-East Europe is a joint effort between "N. N. MiklouhoMaklay" Institute of Ethnology and Anthropology Russian Academy of Sciences in Moscow, Russia, and the Institute of Ethnography of the Serbian Academy of Sciences and Arts, Belgrade, Serbia. The idea for this volume came about at the international conference Retrospectives and Perspectives of Ethnology and Anthropology, held from the 8th to the 10th of September 2017 at the open air museum "Staro selo" in Sirogojno, Serbia. The occasion for the conference was the 70th anniversary of the founding of the Institute of Ethnography SASA. The conference was attended by more than 50 scholars from 11 countries, with the main topic being the history and development of ethnology and anthropology, theories, methodologies and research topics, as well as contemporary fields of research and approaches. This edited volume is also the result of a decades long fruitful collaboration between two scientific institutes, that was formalized through the signing of the Protocol on international scientific collaboration between SASA and RAS in 2006

This volume is comprised of topics and presentations given at the jubilee conference of the Institute of Ethnography SASA. Aside from the scientific impact of the individual papers published here, the book also represents an important publication for any future research on the development of ethnology and anthropology in Southeastern Europe. In that sense, the papers presented here as well as the topics they deal with and methods they employ comprise a kind of overview of the issues, research methodologies, concepts and phenomena anthropology in this region engages with in the teen years of the $21^{\text {st }}$ century. The papers published in this volume deal with theoretical scrutiny of the positions of the discipline itself, the analysis of the transformations of traditional culture, as well as various phenomena of contemporary culture in Southeastern Europe.

This volume is divided into three parts. The first, "Networking" and identity - contemporary ethnological and anthropological (self)reflection - is dedicated to theoretical and 
methodological questioning of ethnology and anthropology in the conditions of desired interdisciplinarity and "project" research, as well as paneuropean and international mobility and connection, that lead to changes in the relationship toward "classic" ethnological topics of national identity and folk tradition, as well as to changes in the status of ethnology and anthropology among the humanities. The second part - The new clothes of traditions - deals with the transformations of folk traditions in the modern world and contemporary approaches to traditional phenomena. The third part - (Post)modern games and rituals - encompasses anthropological research into phenomena that came into being in the periods of modernism and postmodernism, and their relationship with ideological, national and religious identities.

The paper that opens the first chapter is by Ines Prica (The Institute of Ethnology and Folkloristics, Zagreb), Delivery of Ethnographic Material. The Work of Ethnologists in the Conditions of "Project Interdisciplinarity", in which the author considers the state of ethnology and the humanities in the conditions of interdisciplinarity and the "projectification" of science. The author focuses on changes in perception and the performativity of ethnology in the context of interdisciplinary projects, which leads to the fact that a general ethnological overview is often left without key disciplinary bases, which subsequently leads to the reduction of the professional work of ethnologists, and their relegation to "purveyors of material" for further analytic procedures. Petko Hristov (The Institufe of Ethnography BAS, Bulgaria) in the paper Multidimensional Identity and National Tradition under the Conditions of Pan-European Mobility. Is Ethnology of a United Europe Possible? analyzes the challenges which the new millennium, followed by the changes in socio-political climate (the fall of the Iron curtain, the spread of the EU and the drastic transformation of the southeastern part of Europe) brought to ethnologists in the Balkans. These changes were evident in the change of the subjects of ethnological research, as well as in the construction of multidimensional identities in Europe. The conditions of panEuropean mobility influence the changes in the nature of national identity and the relationship toward cultural and historical heritage which is understood as "folk tradition". 
The second part The New Clothes of Folk Traditions opens with a paper by Milan Tomašević (The Institute of Ethnography SASA, Serbia), entitled Anthropological Interpretation of Popular Cosmology: Research Perspectives. The paper researches the relationship between popular culture, science, religion and anthropology, and through analyzing popular cosmological theories arrives at a conclusion about the relations of power and identity in modern society, with a specific regard to the "cultural wars" that took place at the beginning of the new century. Through the application of semiotic analysis, the author views popular cosmologies as contemporary folk narrative forms and as "secular mythology". The paper by Vesna Petreska (The Institute of Folklore "Marko Cepenkov", Macedonia) Ritual Kinship in some Calendar Celebrations. A Case Study of the Celebration of Epiphany in Macedonia analyzes "kumstvo" as ritual kinship in the celebrations of St. John and Epiphany, by relying foremost on the theory of practice by Pierre Bourdieu. The paper considers the multifunctional meaning of ritual kinship in modern times - with can be viewed as an actualization of re-activization of tradition and its popularization in modern times, which might turn into the commercialization of identity within the context of cultural, religious and rural tourism; as protection of immaterial cultural heritage; as cultural remembrance connected to identity, and as "symbolic capital". The paper by Đorđina Trubarac Matić (Institute of Ethnography SASA), From the Classical Serbian Epics to The Hague Thematic Circle and Back: Decasyllabic Singing as a Linguistic Register Seen from the Functional Perspective deals with the traditional folk phenomenon of guslar epic poetry in contemporary conditions, through the application of modern anthropological approaches. Contemporary guslar singing and decasyllable songs are viewed as a complex phenomenon, both from a thematic and a functional point of view. The author concludes that the epic songs concerning the occurrences and the actors of the 1990's are just another subtype of contemporary Serbian epics. Because of this she bypasses the reductionist interpretations which view contemporary guslar singing only in the context of growing nationalism and the promotion of extreme nationalist and warmongering ideas, and espouses an approach which promotes the "new" guslar poetry and 
epics as one of the historically attested registries of the Serbian language, which should be valued outside its ethical/ideological value scopes. Katerina Petrovska Kuzmanova (The Institute for Folklore "Marko Cepenkov", Macedonia) contributes with a paper entitled Aspects of the Research of the Role of Rusalian Processions in Folk Tradition, in which she researches rusal processions, which have always been in the focus of folklorists and ethnologists because of their syncretic form, complex organization, the specifics of the clothing and dance, and the taboos connected to them. The complexity of this ritual opens the possibility for various scientific interpretations, and Kuzmanova decides to utilize a comparative analysis of traditional and contemporary aspects of rusal processions, and their meanings and social functions.

The third chapter of the edited volume (Post)modern Games and Rituals is dedicated to the analysis of cultural phenomena the emergence of which is connected to the ages of modernism and postmodernism. In the paper entitled The celebration of children's birthdays in Belgrade and consumer society by Aleksandar Krel and Jadranka Đorđević Crnobrnja (Institute of Ethnography SASA), the focus is on the celebration of children's birthdays as a meaningful form of contemporary social and cultural practice, which began in Serbia in the interbellum period. In the second half of the $20^{\text {th }}$ century this practice gained the status of the most important family celebration in both urban and rural environments. This cultural practice, as the authors deem, manifests the compliance with the markers of consumer society and its dominant ideals - thus its transformations from the socialist to the post-socialist era, marked by neoliberal political ideas. Ivan Đorđević (Institute of Ethnography SASA), in the paper Politics on the Football Field. An overview of the relationship between ideology and sport in Serbia deals with the historical context of the relationship between football and ideology, starting with the period between the end of WWII until the end of the 1980's, when football had a role in the activities of communist and socialist ideology, and the ideological turning point since the 1980's, when groups of supporters became the bearers of nationalist ideology. The third segment of the paper refers to the period after the wars of the 1990's and the turn toward European values. The author notices the importance of supporter 
groups as political actors that reflect the ideological divide within Serbian society, acting both as subjects of neoliberal European politics and as keepers of national identity, whose nationalist component is reactivated as needed. The relationship between "games" and nationalism is also the topic of the paper by Ljiljana Gavrilović (Institute of Ethnography SASA, Serbia), albeit the game takes place in virtual reality: MMORPGs and nationalism. Namely, even if they display a similar form of declarative anationality, and the nominal dominance of state, national and linguistic barriers, characteristic of the physical world, the virtual world of online games has a strong tendency toward making national guilds, connected foremost to one's mother tongue. This, as the author thinks, can also be interpreted as the author thinks, as a wish for better communication within a community, as well as strengthening the cohesion of a community through shared cultural preferences. The analysis focuses on "recruiting" messages of "national" guilds, as well as the behavior and attitudes of players on ethnic and national channels in the MMORPG World of Warcraft. The paper by Biljana Anđelković (Institute of Ethnography SASA, Serbia) Some Basic Factors of Pilgrimage in contemporary Serbia analyzes the modern phenomenon of pilgrimage tourism, which partly relies on the ancient religious phenomenon. Although this is a developed branch of tourism, as the author's insights show, this activity is not regulated, and mostly takes place in the "grey zone". This leaves the organizers of the pilgrimage a lot of freedom in choosing the holy places, as well as the narratives that accompany this activity. The research was conducted between 2013 and 2017 and analyzes the organization and structure of pilgrimage tourist groups and their roles in the development of contemporary religiosity in Serbia.

The research topics and approaches espoused by the aforementioned authors from countries of Southeastern Europe whose papers comprise this volume reflect wider social changes taking place in the contemporary world, as well as the changes in the relations of ethnologists and anthropologists to their own discipline and its role in society. A certain turn is noticeable, from sociocultural anthropology, which was dominant at the end of the $20^{\text {th }}$ century and was marked by modern, "urban" topics, toward "traditional" ethnological themes in a new light, and issues of 
cultural heritage, which are now being approached from different perspectives. What is noticeable, both implicitly and explicitly, is an awareness of ethnology and anthropology about the necessity of a closer reconsideration of immediate ideological engagement, whether it is considered as an involvement in the creation of (national) identity constructs or as their ideological critique, or as the following of globalist neoliberal tendencies. Both folk tradition and contemporary cultural phenomena are viewed foremost as segments of culture, the analysis of which is displaced from superficial social engagement and dominant ideological narratives into the field of scientific interpretation. Because of this, the insight into the consequences of the strengthening of the neoliberal European and globalist doctrine is evident, not only when it comes to the analysis of contemporary culture, but also the position of the humanities, especially ethnology and anthropology. Namely, ethnology and anthropology has, in Southeastern Europe, along with other humanities, found itself simultaneously in the traps of the attempts to instrumentalize it to the benefit of "national" state projects and their identity politics, and also in the service of neocolonial tendencies, trying to shield itself from utter social marginalization, while resisting the ideology of the "applicability" of science. Thus, this volume is characterized by a plurality of topics and theoretical and methodological approaches, a following of contemporary global scientific flows, but with a knowledge of the specificities of the societies studied and the position of ethnology and anthropology in them. Judging by the papers in this volume, in the early $21^{\text {st }}$ century, anthropology and ethnology in Southeastern Europe will be marked by questioning its position with regard to societies positioned between re-traditionalization and neoliberalism, and between the applicability of research in the creation of public policy and a resistance to becoming mere instruments of it. It will be marked by the plurality of research topics and methods, while also striving to, through the inevitable influence of interdisciplinarity, followed by the bureaucratization and (potential) instrumentalization of science, maintain its interpretative sovereignty and research autonomy. 
I. "NETWORKING" AND IDENTITY - CONTEMPORARY ETHNOLOGICAL AND ANTHROPOLOGICAL (SELF)REFLECTION 

Ines Prica

\section{Delivery of Ethnographic Material. The Work of Ethnologists in the Conditions of "Project INTERDISCIPLINARITY" 1}

The paper problematises the new conditions in which the humanities are operating, with special emphasis on the requirements imposed upon the institutional foundation and perception of disciplinary identity by the tendency of projectification. The analysis is more narrowly focused on the change in the perception and performative aspects of ethnology in the context of "project interdisciplinarity". While in such a mosaic common field of various disciplinary claims and goals, it is primarily represented by the symbolic capital of its "famous" ethnographic method, the general ethnological insight, in final outcomes, often left deprived of the key disciplinary strongholds, together with the complex, although somewhat idealistic model of humanistic ethnography. Consequently, the trend leads to the reduction of the professional work of ethnologists to the "suppliers of material" for further analytical procedures and the later finalisation of the scientific product.

Key words: ethnography, interdisciplinarity, projectification

INTRODUCTION: AN ACKNOWLEDGEMENT OF INSTITUTIONS. Institutes like ours ${ }^{2}$, which have somehow managed to survive for decades in a more or less radical conversion of all kinds of (social,

1 This work has been supported by Croatian Science Foundation under the project Transformation of Work in Post-transitional Croatia (IP-201606-7388)

2 The paper was presented in the occasion of the 70th anniversary of the Institute of Ethnography in Belgrade, while the Institute of Ethnology and Folklore Research in Zagreb celebrates the same anniversary this year (2018). 
political, scientific) "regimes", but in a mode of operation based around long-term, "slow" work and research, already represent a sort of historical leftover designated for dismantling within the business aspirations and austerity-based national strategies of all our regional, and especially European, governments. Due to the enforcement of the contemporary criteria for scientific achievement, as that of applicability, excellence and mobility (see Bagarić 2017, Petrić 2013), and the substitution of regular, longterm public financing with, preferably European, project-based funding, the "old" scientific institutions, together with their notorious tendency towards stable employment of scientists, have become the potential enemy of a healthy scientific economy. In the pandemic witch-hunt for "public sector parasites", especially humanistic scientists happen to match perfectly the idea of the ineradicable fiend of the socialist mentality, surviving through those safely nestled in the sinecure of the public institutions. Furthermore, in the competing political strivings of the transitional societies, the increasing interests in the territory of "outdated" institutional activities usually translate the goal of its commercial restructuring in terms of bare ideological platforms (Žitko 2011). This enforces the constant reorganisation of internal relations in the academic field also along the lines of the all kind of contextual conflicts and deals, and through the growing differences in the systemic positions depending on class, gender, age, etc., with the threat of the final elimination of its subjects which varies according to the criteria of the stakeholders' "use value" (more in Prica 2017).

The result is an environment which suggests that the consolidation of common interests, or even the battle for the survival of the humanities, would be performed also as the prefiguration of existing disciplinary and institutional authorities, primarily in the frame of projectification, which has become an independent, "satellite" structure for the trans-institutional precarious performance of scientific activity. The continuous concern for the development and articulation of specific disciplines in the humanities - once considered as the domain of institutions is thus increasingly being subjected to the modus operandi of shortterm, "mosaic" programmes with a strict or even dominant administrative drive, with strongly suggested methods and 
hypotheses preferably to be confirmed. In such an environment, the relationship with the external funder implies also a tacit form of scientific alias existential obedience, while the role of rooted institutions tends to be reduced to providing the basic infrastructural support, including the human resources.

On the other hand, in conditions marked by the structural crisis and "the aberrations of the humanities" (Bagarić, Biti, Škokić 2017; Petrić 2013), as well as increasing precarity, especially among young researchers, the benefits of unimpeded scientific work in existential security, together with the general advantages of "slow science", are more and more rediscovered (see Mountz et al. 2015). The frequent references to the "vintage values" of scientific work indicate that we are witnessing the bitter results of its postinstitutional, or even "post-scientific", stage, marked by the nostalgic reminiscence on the identity of the humanistic field in its designated ideal from the 1960s.

Accordingly, such circumstances demand a new frame for reflecting on the disciplinary status in the humanities: usually considered in terms of the autonomous horizontal growth, the shift would now imply (re)inventing such an interdisciplinary frame in which acting from the position of the identity of the discipline should be replaced with the priority of consensus on integral identity of humanities, including its inherent, dialogical interdisciplinary quality and striving for the possibility of social change as its neglected, or even deserted purpose.

"PROJECT INTERDISCIPLINARITY" AND THE LIMITS OF HUMANISTIC ETHNOGRAPHY. In the meantime, however, the idealistic concept of interdisciplinarity as a field of translatability and the incorporability of various approaches within the frame of common humanistic subject, has been replaced by the more pragmatic practice of "project interdisciplinarity". The latter can be described as the frame of juxtaposition of various disciplinary and methodological interests, mixing quantitative and qualitative approaches, and with the inclination to hierarchization of knowledge, both on the basis of "objectivity" of methodological outcomes (preferring quantitative 
results), and on the basis of the locality of the research position, latently or blatantly preferring central to peripheral insights (more in Buchowski 2004; Prica 1995).

For the very ethnological contribution, it means that it tends to be positioned at the level of local insights, the purpose of which is to provide illustrations and examples, and at the end, the confirmations of the provided hypothesis with the help of fragmented textual evidence of the authentic human experience. While in this "disciplinary market" ethnology is primarily represented by the symbolic capital of the ethnographic method, its professional contribution is often deprived of the key epistemological strongholds, failing to reach the full disciplinary frame, together with the complex model of humanistic ethnography. Consequently, the trend leads to the reduction of the work of ethnologists to that of suppliers of material for further analytical procedures and "later" finalisation of the scientific product. Moreover, the "literary" elements, arbitrariness, incompleteness, and other supposed deficiencies of the ethnographic contribution, put it in an a priori lower rank towards more objective findings, preferably the knowledge obtained by quantitative methodologies.

Such a displacement from the hypothetical core of interdisciplinarity can be detected in the inherited marginal status of ethnology, the epistemological position of "belonging nowhere" within the discourses of the humanities (e.g. in Foucault 2002). However, it has maybe more to do with the contemporary status of ethnography belonging everywhere in the same domain: the ambivalent methodological position which can easily reproduce the hierarchy of "primary insights" and elevated instances of knowledge. And while, in its recent scientific history, ethnologists have undertaken a lot of ethic-epistemological efforts and selfdenials reworking its "positivist quilt" - using various uncertain tactics of verification and translation of immediate research experience in order to make plausible and unbiased models of its (re)presentation - now the ethnography, in its "raw" descriptive form, easily ends up to be the groundwork for final analytical readjustments. Mostly by (crypto)quantitative interventions suited to criteria of applicability of results, ethnographic fragments are 
subjected to the interpretations with a significant loss of credibility - the impact of implied theoretical frame and situational context.

Therefore, the fate of experience-based, documentary, descriptive ethnographic discourse, the standard-bearer of the qualitative approach and the safeguard for humanistic-scientific identity, leaves behind an untranslatable, not just scientific, but also authentically human(istic) surplus. Knowledge obtained through field research is thus becoming the battlefield for positioning and verifying the academic subjects through which human experience cannot be truly evoked but rather "smuggled". Instead of naively seeing it as "unreducable" within the different forms of knowledge and scientific discourses, there are now more and more indications to see this "surplus of life" as useless or even undesirable, while condemned to an indifferent and helpless space in which common humanistic interest operates today.

On the other hand, the problem of the "proper" humanistic ethnography lies also in the heavily reachable requisites of its materialization.

The numerous demands which, during past decades, have been placed before ethnographic "writing culture", most of which succumb to the uncertain procedures of authentication, have been summarised in probably their most elaborate form in the famous Manifesto for Ethnography by Paul Willis and Mats Trondam (2002). Keeping in mind that direct and sustained social contact with other people does not make it easier to subsequently describe the irreducible human experience, but rather places trust in the author's presentation of their "unique sense of embodied existence and consciousness" ("the human condition from the inside"), the manifesto also indicates the position of ethnography compared to the autonomous discourse of anthropological and social theory. Understanding and presenting experience plays a central role in both empirical work and theory; therefore, "ethnography and theory should be conjoined to produce a concrete sense of the social as internally sprung and dialectically produced" (Willis \& Trondam 2002, 395). The idea of humanistic ethnography inherently implies that it is theoretically informed "in itself": rather than referring to the application of the existing "overfunctionalist, overstructuralist, 
and overtheorised views", this stands for the "positive development of reflexive forms of social theorizing, allowing a voice to those who live their conditions of existence" (Ibid.).

"For us, though, theory must be useful theory in relation to ethnographic evidence and the 'scientific energy' derived from the effective formulation of problems, rather than theory for itself. It must be of help in understanding social phenomena in relation to ethnographic evidence. So, we are not interested in 'grand theory', 'pure' scholastic reason, or 'abstracted' empiricism. We seek to promote 'theoretical informedness', 'sensitizing concepts', 'analytic points', all means of teasing out patterns from the texture of everyday life, from 'pure' descriptive ethnography. These may sometimes be gathered and mobilized for more connected theoretical contributions, but although we do, in general, see ourselves absolutely within a broad project of the reflexive understanding of contemporary society, we do so primarily from a basis within the ethnographic observation of continuity and change" (Willis \& Trondam 2002, 396).

The theoreticity of ethnography is, thus, not something separate from, added or opposed to its primarily descriptive character. Therefore, ethnography is not subjected to procedures of radical rewriting within the framework of other discourses or various forms of "interdisciplinary" adjustments, as "we do not want to provide ethnographic evidence simply to exemplify or adjudicate between opposing and pre-existing theoretical views" (Ibid., 398).

On the contrary, "we argue that theoretically informed ethnographic writing has a crucial role to play in reshaping 'theory' and in finding accommodations between, as well as forging new lines and directions from, social theorists" (Ibid., 396).

The identification, recording and analysis of "common" human praxis must strive to accommodate its openness, unpredictability and its potential to "surprise": it must produce knowledge which is not preconceived, as well as create a base for 
further refinement and reformulation of one's initial theoretical positions $^{3}$.

Standing for the experience-based cognition of the complexity of the cultural situation, the ethnographic material is thus not simply a common repository of rudimentary findings which can be freely dismantled and organised in autonomous linear narratives, in accordance with the established concepts (or policy recommendation), as to be the final instance of evaluation of majority of project-based scientific politics.

The precondition for a purposeful humanistic ethnography is, therefore, the abolition of the hierarchy of knowledge in any form of apriority, but the question that remains, nevertheless, is whether such a "perfect" ethnography is even attainable, and if it is, what is its immediate social purpose.

RESETTING ETHNOLOGICAL SUBJECT FROM THE PERIPHERY. If we agree that the fundamental purpose of humanistic ethnography "changing the social within the social" - is not exhausted within the scope of its academic ideal, i.e. the methodologically adequate description of the potential for social criticism and change embedded within everyday praxis, then post-colonial criticism has raised the most uncomfortable question of its socially engaged

3 "However, the nitty-gritty of everyday life cannot be presented as raw, unmediated data-the empiricist fallacy, data speaking for themselvesnor can it be presented through abstract theoretical categories - the theoreticist and idealist trap, the lack of interest in empirical findings. (...) Ethnography is the sensitive register of how experience and culture indicate, as well as help to constitute, profound social and structural change, but that change and continuity in change have to be conceptualized in ways not contained in ethnographic data themselves. The trick is to bring that 'registered experience' into a productive but unfussy relation to 'theory', so maximizing the illumination of wider change. (Theoretically informed ethnography) seeks to establish analytically productive relations between theory and data, the two most important poles or dimensions of the dialectic of surprise, so escaping the usual banishment of theory to the ghettoized 'theory section' devoid of aha effects" (Ibid., 399). 
potential. As perhaps the most sophisticated procedure for dealing with the effects of rational discourses, whose biased politics of representation had the effect of shaping and reinforcing various forms of hegemony, post-colonial criticism subscribes to the critique of those forms of anthropological "scholarly activism" which remain trapped within the confines of academism.

Thus all the types of engaged ethnography within the scope of western anthropology, including their innovative, corrective and even militant variants, keep staggering on the ground of policies of representation and advocacy. On the other side, we can recognize the different kind of "activist" impulse characteristic for the so called national ethnologies of continental/European scientific traditions. Performing their social agency through the carnivalesque notion of folklore, as the mechanism defying the hegemonic relations through tacit forms of cultural resistance, this theoretical narrative, nevertheless, has somehow ended up in the normalising effects towards models of resistance in consumer societies, reducing it to "rebelliousness" through consumption and fetishization of popular culture (see more in Prica, 2001).

So, if we are now faced with the question of the place and the responsibility of ethnology within the global neoliberal crisis of the humanities, we ought to ask ourselves how and to what extent is it affected with a certain passivistic quality brought about by its own (post)paradigmatic crisis.

One of the significant consequences of the epistemological and academic restructuring of the discourses of humanities and social sciences from the end of last century, is that ethnography (as the former disciplinary "property" of ethnology and anthropology) has been inaugurated as an independent methodological domain radiating to the entire interdisciplinary field. As the document of human experience, ethnography - tactically amnestied of its manipulative, positivist epistemological status - suddenly appears as the guarantor of the empirical authenticity, either of "old" disciplines like sociology or historiography, or new academic paradigms striving for a synthesis of the entire humanistic field, as cultural studies. 
However, as has already been stressed, the introduction and legitimisation of ethnography as a common humanistic field has not automatically resulted in any "interdisciplinary idyll": for its methodological, theoretical and teleological potential, it means that it can be susceptible to various kinds of reductions and appropriations.

Set free from the epistemological and textual constraints, most of which have been permanently put on hold, ethnography has found itself at the centre of the reappointment of disciplinary authorities, especially in the post-socialist transformations of European hierarchies of knowledge (Buchowski 2006).

Such a transitional environment, performed through the prolonged processes of Europeanization, proved particularly beneficial for the reproduction of scientific and social subordinations, while in the euphoric rejection of previous "ideological dictates", it has abolished also the tradition and practice of the - allegedly unavoidably parochial and instrumentalised national ethnologies (Prica 2004, 2006).

The ethnological heritage of Southeast Europe was particularly liable to losing the equal position in the newly established field of European anthropology. Ignored for the theoretical and interpretative efforts developed during the period of socialist modernization, the interest shifts entirely to the documentary abundance of its exciting domestic terrains. The position of the informed and theoretically refined population of "ethnologists in transition", in the espoused conditions has mostly been reduced to the provision of insider insights and collecting material from primary cultural sources.

There is, thus, a justified analytical impulse to recover the frozen potentials of the neglected ethnological heritage, especially of the ex-Yugoslav space. Beyond the routine and reductionist critique of its ideologically distorted or "parochial" practices, the modernist turns and various forms of critical writings, here also brought about important outcomes. Contrary to the well-established notions of the post-socialist moment as the beginning of their liberation and "normalization", the eclectic interpretational interests as well as the 
early deconstructive impulses from the beginning of the 70's, has made a strong platform for dismantling the concepts of nation and identity, performing also as the process of anthropologization before the explicit translation and legalization of the local ethnological traditions within recognisable (western) anthropological terms, as the opportunistic outcome of its post 1989 adaptations. Moreover, the imperative of urgent ethnographic documenting of cultural phenomena in light of global changes has encouraged exactly a regressive shift in former self-reflective forms of writing, evoking the positivist discourses from the beginning of the last century.

Today, it is up to us primarily to consider the systemic conditions for the peripheralisation as the production of global cultural-economical inequality, where disclosure and subversion of the politically opportune academic forms plays one of the crucial roles.

\section{References}

Bagarić, Petar. 2017. „Kriteriji izvrsnosti u humanistici.” U Stranputice humanistike. eds. Bagarić, Biti i Škokić, 76-89. Zagreb: Institut za etnologiju i folkloristiku, Biblioteka Nova etnografija.

Buchowski, Michal. 2004. "Hierarchies of Knowledge in CentralEastern European Anthropology." Anthropology of East Europe Review 22 (2): 5-14.

Buchowski, Michal. 2006. "The Specter of orientalism in Europe: From Exotic Other to Stigmatized Brother." Anthropological Quarterly 79 (3): 463-482.

Foucault, Michel. 2002 (1966). Riječi i stvari. Arheologija humanističkih znanosti. Zagreb: Goldenmarketing.

Mountz, Alison, Anne Bonds, Becky Mansfield, Jenna Loyd, Jennifer Hyndman, Margaret Walton-Roberts, Ranu Basu, Risa Whitson, Roberta Hawkins, Trina Hamilton, and Winifred Curran. 2015. "For Slow Scholarship: A Feminist Politics of Resistance through Collective Action in the Neoliberal 
University."ACME: An International Journal for Critical Geographies $14 \quad$ (4): 1235-59. https://www.acmejournal.org/index.php/acme/article/view/1058.

Petrić, Mirko. 2013. „Akademski kapitalizam i uloga sociologije.” Revija za sociologiju 43: 273-288.

Prica, Ines. 1995. "To be here - to publish there. On the Position of a Small European Ethnology." Narodna umjetnost 32(1): 725.

Prica, Ines. 2004. „Nasljeđe jugoslavenskih etnologija i suvremeno istraživanje postsocijalizma.” Traditiones, Zbornik Instituta za slovensko narodopisje Instituta ZRI SAZU. 33(1): 19-35.

Prica, Ines. 2006. „Etnologija postsocijalizma i prije: Ili dvanaest godina nakon 'Etnologije socijalizma $i$ poslije'." U Devijacije $i$ promašaji: etnografija domaćeg socijalizma, ur. Ines Prica $i$ Lada Čale Feldman, 9-25. Zagreb: Institut za etnologiju i folkloristiku. Biblioteka Nova etnografija,

Prica, Ines. 2017. „Potrebe duše, potrebe gospodarstva: autonomija i primjena humanistike na periferiji." U Stranputice humanistike. ur. Bagarić, Biti i Škokić, 76-89. Zagreb: Institut za etnologiju i folkloristiku, Biblioteka Nova etnografija.

Willis, Paul and Mats Trondman. 2002. "Manifesto for Ethnography." Cultural Studies $\leftrightarrow$ Critical Methodologies 2(3): 394-402.

Žitko, Mislav. 2011. „Autonomija, konverzija i status quo: Prema morfologiji akademskog polja." U Horror, porno, enuii: kulturne prakse postsocijalizma, ur. Ines Prica i Tea Škokić. Zagreb: Biblioteka Nova etnografija. Institut za etnologiju i folkloristiku. 



\section{MULTIDIMENSIONAL IDENTITY AND NATIONAL Tradition Under The Conditions of PAN- EUROPEAN MOBILITY. IS ETHNOLOGY OF A UNITED EuROPE POSSIBLE?}

The beginning of the new millennium posed new challenges for ethnologists from the Balkans. The fall of the Iron Curtain and the enlargement of the EU, the dissolution of multinational states such as Yugoslavia and the USSR, the candidature of Turkey which dragged on in time and the setting of new EU borders in the Balkans drastically transformed the map of this corner of Europe. The subject of ethnological studies has changed and the construction of multidimensional identities in European countries has become a rule rather than an exception. Under the conditions of pan-European mobility, the nature of national identity as well as the attitude towards cultural and historical heritage (understood as "national tradition") as its main basis is changing. The questions which ethnological studies in Europe, and particularly in the Balkans, face become more and more numerous and the search for answers - more and more responsible. The article share some observations in this respect.

Key words: identity, tradition, pan-European mobility, ethnology, United Europe

The new millennium and the dynamic political transition and social changes in Eastern and South-Eastern Europe at the beginning of the 1990s brought significant changes in the ideas concerning the ways in which nations and national identities are constructed. If the $19^{\text {th }}$ century nationalists believed in the possibility of the creation of stable and clearly defined nation-states, and the sociologists and the philosophers of the $20^{\text {th }}$ century 
pessimistically predicted the end of history and the possibility of existence of a homogeneous world without nations and nationalism, then the active cross-border mobility and transnational migration processes in South-Eastern Europe in the first decade of the $21^{\text {st }}$ century are the main catalyst of the discussions concerning the concept of the homogeneous national identity and national culture (based on "folk tradition"), which were taken for granted.

The optimists aver that liberal democracies can construct "an egalitarian multicultural society" where "it is possible, without threat to the overall unity of the national society, to recognize that minorities have a right to their own language in family and community contexts, the right to practice their own religion, the right to organize domestic and family relations in their own way, and the right to maintain communal customs" (Rex 1995, 30-31). A recent refusal of the Chancellor Angela Merkel to lead multicultural politics in Germany disproves such optimism. And while some authors claim that the nation state is in crisis (Beck 1997), it showed its multiple faces in the past two decades - the collapse of the Soviet Union and Socialist Federal Republic of Yugoslavia have shown how from the decayed multinational "socialist" communities new (and "newly-invented") nation-states are reborn as phoenixes.

We are witnessing similar processes nowadays - we witness the struggle for creation of new nation-states, in which the state, the citizens and their cultures are linked in a variety of linkages, which are far from the ideal "Western" model, requiring that the citizens of the nation-state should share mutual languages, culture and identity (Čapo Žmegač 2008, 323). Until after each of these countries gains the status of an independent nation state its elite is seeking for ways of becoming a member of one or several transnational structures, such as the EU, for example, lead by the administration in Brussels, or the Eurasian union, dominated by Russia. This choice is always difficult and is not always the best as the tentative politics of Ukraine's president Viktor Yanukovych have shown so far. The rapidly developing globalization and trans-border migration processes in South-Eastern Europe, as well as the influence of the transnational organizations and institutions, are creating new conditions and are inculcating new symbolic values when the 
dynamic and transitional national identities are constructed (Angulo 2008, 154); but on the other hand, this is accompanied by an increased significance of the self-identification with the diverse local communities (Hristov 2012-a, 214). "New" Europe is changing before our eyes.

The double transition process of the East European countries - towards the Western European model of liberal democracy, and at the same time, towards capitalism, i.e. the removal of the states' hegemony over the economy, conjuncts with the new phase of the development of capitalism and globalization. In a number of countries (such as Bulgaria for example) all this was accompanied by decomposition of numerous economic, political and social structures, which previously played a crucial role in society for more than forty years. The 1990s have shown the insolvency of the political concept of the "historical reversibility" towards the social reality of the pre-socialist epoch; the attempts of some politicians in Eastern Europe to restore the relations in their countries to the starting point of the period before World War II in order to eliminate the decades of the socialist social experiment failed. In Bulgaria, for example, the restitution of the agricultural land to "its actual bounds" of the period before the mass collectivization in the end of the 1940s ended with a crash of the agrarian sector in the country (Hristov 2013, 131). Generally, the integration of the Eastern European countries into the EU has constituted both a goal and the road towards the transformation of pre-existing economic, social and political structure and towards the adoption of new symbolic modes of nation building where new meanings and contents are given to national identity (Angulo 2008, 155). Especially in the Balkans, the focus on a nation's heroic past becomes more and more a base motive and main argument for justification of the "European future" perspective.

The fast developing trans-border migration to Western Europe can be interpreted as the creation of a "bridge" between the old concepts of national identity, existing in the socialist reality of the former Eastern Bloc and the new understanding of identity, adopted by the people, living in the conditions of pan-European transnational mobility. In this context, the example of the 
gastarbeiters from former Yugoslavia enhances its significance in a comparative Balkan perspective (Hristov 2010, 102). During the last three decades the migration of the Eastern European countries became the main catalyst of the division between territory, nation/society and culture, i.e. the main ideological components of the nation-state idea, as well as for the discussions concerning the concepts of the homogeneous national identity and national culture which are taken for granted (Čapo Žmegač 2008, 323). During the last few months the politics of shared responsibility of the EU, especially in terms of the new refugee wave, which hit Western Europe, is seriously questioned; the capability of the European governments to manage to accept so many migrant groups and communities, coming from diverse religious, cultural and linguistic backgrounds, is seriously tested. Consider the following as an example - as a reaction to the immense refugee wave, pushing mainly out of the Islamic countries in the Middle East towards Europe, Saudi Arabia recently suggested, as a sign of solidarity, to build 200 new mosques for the new migrants ${ }^{1}$. Clearly, the religious, cultural and language similarity of the majority of the last wave refugees with the Middle East does not bear a great significance for the choice of migration destination - the main goal is Western Europe and the European Union narrated among the migrants as the "Promised land". Thus, we can definitely say that "our" Europe is not the same anymore, neither for those born in it, nor for the migrants aspiring to begin their new lives here.

In that sense, how can we think of a new "European Ethnology" and what would be the place of the Balkan ethnologists and anthropologists in it? How does the subject of study change and what methodology and research strategies would be the most adequate to the rapidly changing mosaic of ethnic, confessional, cultural and linguistic communities in the, still largely considered as national, countries on our continent?

${ }^{1} \mathrm{http} / /$ www.independent.co.uk/news/world/europe/saudi-arabiaoffers-germany-200-mosques--one-for-every-100-refugees-who-arrivedlast-weekend-10495082.html 
Primarily, we should realize what are the difficulties which stand before the researchers who are trying to perceive the Balkans as a unified entity. The emergence of the new term "Western Balkans" which is politically constructed and proclaimed to be of priority to the Bulgarian presidency of the Council of the European Union reminds of the new dividing lines which have emerged after the fall of the Berlin Wall. Additionally, here comes the problem of the different content, implicated in notions such as ethnicity, identity, national tradition etc. Contrary to the European tendencies for boundlessness, I would suggest that today the Balkans can be described through numerous alternatives for the notion of borders, understood as in the meaning implicated by post-Barth anthropology, as ethnic, religious, cultural, and later on - stateborders. After the volume of Frederic Barth had been published in 1969 (Barth 1969), nominated as a "Copernicus revolution in the ethnicity problematic" by some authors, it became evident that ethnicity is revealed for us primarily as an equilibrium of proximity and difference, i.e. identity/ otherness (Gossiaux 2002, 24).

The Balkans reveal themselves throughout their millennial history especially as a border and contact zone between two civilizations and cultures, a place of clashes and conflicts, but also a place of mutual infiltration, impact and synthesis. Throughout the centuries, a number of ethnic, religious and culturally different groups, which have learnt at least to some extent to live together, have coexisted in this part of Europe. In that sense, from an ethnological point of view - both in culture and language, the borders in the Balkans do not match the state ones and are not the thin lines on the maps, which we can move violently or voluntarily through wars and/or agreements; these are wide border areas, where the cultural mosaic contains diverse elements of the culture of the neighbouring peoples, commonly perceived as "own". But instead of being proud to share their shared cultural heritage and common historical past, the different countries eagerly defend their "unique" heritage and by rejecting the claims of the others proclaim it to be "authentic national tradition". The Balkan countries are seeking to split their common cultural experience, keeping, nevertheless, the cultural attainments for themselves. 
In ethnology and anthropology the understanding of "tradition" has enjoyed a long-standing popularity among scholars (Feintuch 2001, 470) as a very important historically formulated component of culture, often used in opposition to the processes of modernization (Kearney 2001, 326). In America, Franz Boas viewed "tradition", "folklore" and "culture" as overlapping and amalgamated. In Europe, under the influence of the evolutionist paradigm, most importantly Edward Taylor's book Primitive culture (1871), the notion of "traditional" culture and folklore as "cultural heritage", as "living antiquity", passed on from ancestors to contemporaries emerged. In many places in Europe, particularly in the Balkans, ethnology and folklore studies appeared during the $19^{\text {th }}$ century in the context of national liberation movements and as part of the efforts for conceiving national ideologies Angulo different nations to be created and legitimized, especially in the context of multinational empires such as the Ottoman and the Habsburg. For regional researchers from the mid-19th and the early $20^{\text {th }}$ century, "tradition" possessed a certain antiquity, while naming a given artefact as "traditional" meant to directly relate it to another, hard to define concept (Feintuch 2001, 470): "authenticity". During this period of development of the scholarly disciplines, characterising something as "traditional" or "authentic" most often meant to place it against the process of modernisation. Here we can agree with contemporary sociologists that, in the context of culture, the idea of "tradition" is a product of modernity (Giddens 2005, 6566).

To ethnologists and folklorists of the 19th and the first half of the $20^{\text {th }}$ century, proclaiming an artefact as "traditional", as part of the people's "cultural tradition", meant giving it considerable social importance, turning it into a part of cultural heritage that had to be preserved, protected and passed on to younger generations. And the Balkan ethnologists, "the double insiders" according to Slobodan Naumović's famous definition (Naumović 1998, 101-120), are not only researchers but also - in the age of national liberation movements - "advocates" of their research subject: the national communities to which they belong. In addition: many of them took part in building national ideologies and national myths through their research. This national ideology, in which the value of the past 
is uncritically given to "folk tradition" as part of the "people's cultural treasure" (Беновска-Събкова 2004, 30), undoubtedly turns it into an ideological construct. Thus, the work of ethnographers and folklorists turns into a sort of "rescue" expedition that aims to document and preserve for subsequent generations the ancient layers of "folk culture", of the "living antiquity" that is being killed by advancing modernity and urban culture.

As early as the first half of the $19^{\text {th }}$ century the "fathers" of Balkan ethnological research turned to the past and gave priority to old people's narratives and recollections. Each generation of patriotic researchers mourned the disappearance of "tradition", the loss of the "golden age" of folk culture and the abandonment of "pure" pastoral virtues, while at the present time folk culture is described as "remnants" of this past. Studying folk culture was accompanied by the understanding of "tradition" not as a process of passing on cultural values and stereotypes but as a stable, unchanging cultural knowledge that had to be sought again in the past (Беновска-Събкова 2004, 30).

Such perspective on traditional culture foretells "the end of ethnology" for each forthcoming generation of researchers. Additionally, these "fragments" of the culture of still vital (according to the researchers) tradition are turned into "cultural heritage" and "valuable cultural artefacts" for each following generation of ethnographers and folklorists. I will provide only a brief example here. Despite the fact that the American agricultural products were introduced into Bulgarian agriculture during the Ottoman Empire, they become "traditional" very soon. Therefore, the bean soup/beans became Bulgarian "national food" in the 19th century (Генчев 1984, 25).

Similarly to the changed view of ethnic identity as a process of construction, the view of "tradition" as an interpretation of the cultural past is gradually making its way in Balkan ethnology. As I have argued in previous research on the difficulties faced by comparative ethnological research in the Balkans, especially in the border regions, these are due to the non-critical understanding of ethnic identity as primordial - given once and for all - still 
predominant among researchers (Hristov 2009, 114-115). Such a view, used as an interpretative strategy by both historians and ethnologists in the Balkans (Naumović 1998, 101-120), relies on "tradition" as a cultural "basis", on the myth of the "golden age" of national Renaissance and on the firm national roots of folk culture, understood as pastoral-patriarchal and sought in villages (Naumović 1995, 114-128). This "folk tradition" has to be preserved, reproduced and (mandatorily) passed on to coming generations.

Taken by themselves, though, the inherited religion, language, traditions and culture still do not constitute ethnic identity (Altermatt 1995, 62). For a number of European ethnologists, the process of ethnogenesis is mainly a developing sense of unity, regardless of what it is based on (Шнирельман 1999). A system of cultural symbols always belongs to "tradition"; these symbols can change their shape and configuration, but possess the function of maintaining (by replication) internal group integration and distinction from the others; their task is to maintain the ethnic identity of the nation-state. Our ethnicity is a product of specific historical development, of a shared social life within a society composed of a plethora of social groups. In these conditions of prolonged cultural contact and sharing the society and the social space become divided along the line of identity/otherness (Gossiaux $2002,21)$, i.e. of belonging/non-belonging. For the researcher it is of particular importance to analyse in every separate case and historical instance the aggregation of ways, means and strategies of construction, used to preserve and strengthen, or conversely, to remove ethnical boundaries. In my opinion, precisely this should be presented as a perspective for research to the future ethnologists in the Balkans - our university courses could encourage such deconstructions.

The new opportunities for mobility under the conditions of open European borders put in a new context and present in a new manner the relations between the nation-state and the diaspora historical and newly-formed. In the case of Bulgaria we have witnessed the changing cultural strategies both in the relations between the state and the Bulgarian diaspora in modern Ukraine 
formed in the beginning of $19^{\text {th }}$ century (cf. Hristov 2014, 33-47) and in these with the newly formed Bulgarian migrant communities in the US and EU, which followed the democratic changes in Eastern Europe. The diaspora is assigned an important place in the fastdeveloping processes of transformations of national identities in the countries of Eastern Europe - in the receiving country as well as in the countries of origin (Vertovec 2009, 94-95). In the last two decades, in a number of Balkan countries one can often hear in various social circles - academic as well as political, that the demographic crisis in their countries could be settled by "importing" ethnic population from the historical diaspora; there are calls for "returning to the historical motherland" and offers of social and cultural privileges. Let us only recall the fact that in every country in the Balkans there exists the romantic myth, often employed by the nationalists, claiming that their state borders with lands populated with co-nationals/compatriots left under exterior political power. But these views are changed under the new social conditions - under the circumstances of pan-European mobility the social networks change drastically into cross-border and transnationalism becomes an important interpretative frame for the analysis of the multidimensional identities of modern people (Vertovec 2009). In many cases a peculiar malleable identity can be observed among the young representatives of the diaspora (cf. Hristov 2014, 44-45).

The history of integration of the European countries shows one of the possible ways of overcoming the restrictions of the political boundaries of the nation-states. More than 30 years ago Jean Monnet described the future Homo Europaeus as a "transnational, 'post-national' actor who would rise above parochial attachments to locality or nation" (Čapo Žmegač 2008, 336); he would become a rootless cosmopolitan, a deterritorialised Bohemian who would epitomize the various ideals of Enlightenment rationalism (Shore 1999, 64). On the other hand, Robert Schuman wrote in his famous declaration on the occasion of the fifth anniversary since the end of World War II (May 9, 1950): "Europe will not be made all at once, or according to a single plan. It will be built through concrete achievements which first create a de facto solidarity". 
As a number of analyses show, the EU will not only refuse to reject the logic of nationalism in the future, it will not turn into a post-national society delivering supra-national identity of its members, but it has, notwithstanding its rhetoric, reaffirmed national identities (Martiniello 2000, 354). Moreover - in the conditions of pan-European mobility the newly-emerged globallocal dynamics of the cultural management and the attitude towards it, which we recognize as "national tradition", has become a central concept in terms of identity work (Hristov 2012, 985-993). My earlier research among the returnee gastarbeiters in Croatia, Serbia and the Republic of Macedonia shows that once they looked into "the mirror of otherness" in the multicultural environment of the $\mathrm{EU}$, the new returning migrants discovered their strong bond with their birthplaces and gradually developed a local and/or regional identity (Hristov 2010, 102), along with their national identity, and very rarely with the pan-European one.

With regard to the questions raised in the beginning of this paper we can summarise that the rapidly changing image of "United Europe" requires new approaches and a different ethnological and anthropological viewpoint concerning the study of the ethnic, confessional and linguistic diversity of our continent. In the context of pan-European mobility "teaching" "national tradition" to every new generation, the setting of the base of the comparative interpretation of our common cultural past in the Balkans would become a foundation of our common future in a United Europe, a Europe of "unity in diversity". In this respect the role of researchers and university lecturers is substantial. Managing the creation of a unified and unanimous "Europe without borders", of which the Balkans will be an inseparable part, depends to a great extent on the current ethnological perspective on our common cultural heritage. Therefore, young researchers must be trained to research the cultural past of the Balkans in the spirit of shared cultural heritage, enriched via dialogue and interaction through the centuries, thus, eliminating the search for ancient national uniqueness and constructed "authenticity". I would like to see more elaboration on the ways teaching anthropology or ethnology helps European politics of borderless-ness. 


\section{References}

Altermatt, Urs. 1995. Das Fanal von Sarajevo. Ethnonationalismus in Europa. Zürich:Verlag Neue Zürcher Zeitung.

Angulo, Monica Ibañez. 2008. "Nation Building within the European Union: Reframing Bulgarian National Identity from Abroad." In Dynamics of National Identity and Transnational Identities in the Process of European Integration, ed. Marushiakova, E., 154-188. Newcastle: Cambridge Scholars Publishing.

Barth, Frederik, ed. 1969. Ethnic groups and boundaries. The Social Organization of Culture Difference. Oslo:

Universitetsforlaget.

Беновска-Събкова, Милена. 2004. „Размисли върху методите за проучване на традиционната култура в съвремеността." Етнокултуролошки зборник IX: 29-34.

Beck, Ulrich. 1997. Was ist Globalisierung?: Irrtümer des Globalismus - Antworten auf Globalisierung. Frankfurt am Main: Suhrkamp.

Čapo Žmegač, Jasna. 2008. "Parochial Transnationals: Being of Croatian Descent in Germany." In Dynamics of National Identity and Transnational Identities in the Process of European Integration, ed. E. Marushiakova, 323-338. Newcastle: Cambridge Scholars Publishing.

Feintuch, Burt. 2001. "Tradition.” In The Dictionary of Anthropology, ed.Thomas Bariefield, 470-471. Oxford: Blackwell.

Генчев, Стоян. 1984. Народна култура и етнография. София: Наука и изкуство.

Giddens, Anthony. 2002. Runaway World. How Globalisation Is Reshaping Our Lives. New York: Routledge.

Gossiaux, Jean-François. 2002. Pouvoirs ethniques dans les Balkans. Paris: Presses Universitaires de France.

Hristov, Petko. 2009. "Borders and Identities (Difficulties and perspectives faced by comparative ethnological studies of the 
border regions in the Balkans)." Études Balkaniques 3: 109126.

Hristov, Petko. 2012-a. "Migration and New 'Old' Identities: Balkan Patterns." In Migration and Identity: Historical, Cultural and Linguistic Dimensions of Mobility in the Balkan, ed. Petko Hristov, 206-216. Sofia: Paradigma.

Hristov, Petko. 2012-b. "Tradition in the Era of Globalisation - a view from the Central Balkans". Teme 3: 985-994.

Hristov, Petko. 2013. "Inheritance after restitution: modern legislative norms and customary practices in Rural Bulgaria." In Global Villages. Rural and Urban Transformations in Contemporary Bulgaria, ed. Ger Duijzings: 123-136. London: Anthem Press.

Hristov, Petko. 2014. "Multidimensional Identity among the Youth Bulgarians in Diaspora (Case study of Odessa, Ukraine)." Glasnik Etnografskog instituta SANU 62 (1): 33-47.

Kearney, Mihael. 2001. "Modernization." In The Dictionary of Anthropology, ed. Thomas Bariefield: 326-327. 0xford: Blackwell.

Martiniello, Marco. 2000. "Citizenship in the European Union." In. From Migrants to Citizens. Membership in a Changing World, eds. T. Alexander Aleinikoff and Douglas B. Klusmeyer: 342380. Washington DC: Carnegie Endowment for International Peace.

Naumović, Slobodan. 1996. „Od ideje obnove do prakse upotrebe: ogled o odnosu politike i tradicije na primeru savremene Srbije." У од мита до фолка 2, ур. Мирјана Детелић: 109145. Крагујевац: Центар за научна истраживања Српске академије наука и уметости и Универзитета у Крагујевцу.

Naumović, Slobodan. 1998. "Romanticists or Double Insiders? An Essay on the Origins of Ideologised Discourses in Balkan Ethnology." Ethnologia Balkanica 2: 101-120. 
Rex, John. 1995. "Ethnic identity and the nation state: the political sociology of multicultural societies." Social Identities 1(1): 2134.

Shore, Cris. 1999. "Inventing Homo Europaeus. The Cultural Politics of European Integration." Ethnologia Europaea 29(2): 53-66.

Шнирельман, Виктор. 1999. „Национальные символы, этноисторические мифы и этнополитика." In Македония проблемы истории и культуры, ред. Р. П. Гришина, 124135. Москва: Институт славяноведения РАН.

Vertovec, Steven. 2009. Transnationalism. London: Routledge. 

II. THE NEW CLOTHES OF TRADITIONS 

UDK $39+524.8$

DOI: $10.33876 / 978-542-110-238-0 / 43-65$

Milan Tomašević

\section{AN ANTHROPOLOGICAL INTERPRETATION of Popular Cosmology}

This paper represents a short, informative essay on current research into the connections between popular culture, science, religion and anthropology. Using the example of popular cosmology, it points to the relationship between identity, science, philosophy and religion within the framework of contemporary Western society. It also points to the significance of semiotic analysis of the popular cosmological narrative and the possibility of interpreting this narrative as a form of folklore. Furthermore, it emphasizes the social significance of popular science as such, within the contexts of the science and culture wars at the turn of the century.

Key words: popular science, the cosmological narrative, myth, folklore, philosophy of science, purpose, sense, secular myth

COSMOLOGY AND POPULAR CULTURE. Science represents part of an order which sustains epistemological and axiological patterns of the society within which it is created and reproduced. It is the framework on which systems of value and worldviews are built. Regardless of the fact that its basic premise is to be devoid of cultural residue, science is the point in which networks of power relations and identity politics intersect (Barnard and Spencer 2010, 157-159, 632-635). The key reason for undertaking an analysis of popular cosmology lies in the desire to uncover philosophically and anthropologically relevant insights into the consequences it creates in wider social discourse.

Contemporary cosmology plays an important role in our orientation in the word, and the classification of phenomena and processes which determine our place in the Universe. In a way, cosmological theories represent a knowledge basis which we use to 
attribute meaning to everything we face. Cosmology meanders between the means we use to explain natural phenomena and a tool that we use to question our deepest philosophical and religious beliefs - our cultural heritage (Gleiser 2005; Kragh 2007; Barnard and Spencer 2010, 157-159).

The importance of contemporary cosmological theories for philosophical and religious thought cannot be determined in a simple and unequivocal way. Even though they are supposed to be subsystems of culture on the whole, these segments of human knowledge are complexly intertwined. Philosophy of science keeps reminding us that truth is unattainable, as every new discovery births numerous unknowns (Синђелић 2005; Rosenberg 2005; Hackett et al. 2008). Similarly, every breakthrough in theoretical cosmology points to new problems to overcome. On the other hand, religious thought constantly grapples with scientific concepts, in an attempt to reinterpret them and represent them in accordance with its own dogmas. Scientific discovery bends theological exegesis to breaking point. Science points out all the flaws of religious discourse, but it also opens doors for creative approaches to interpreting the world. Research into connections between science and religion in the contemporary world, ways in which religion makes bricolages out of scientific concepts, and ways in which science contests religious dogma, still represent a dynamic field for anthropological research and analyses.

It is my intention to present the contemporary cosmological narrative as it is present in popular culture as a mythological story which possesses a slew of folklore characteristics. Popular cosmology is represented by literature and numerous television programs which serve to introduce cosmological knowledge to a wider audience in a compelling way, especially by suggesting the audience think about the effects this knowledge has on their own lives. I believe that the way in which discoveries pertaining to the origin and evolution of the universe are represented play a major role in the creation of the identity of individuals who adopt this knowledge. Further, I believe that these processes are tightly connected to the creation of personal identity, as people deepen their knowledge about the world around them and question their 
deepest views and beliefs. Popular cosmology breaks down significant philosophical assumptions and cultural fallacies which we espouse through standard upbringing and education. It makes us take a more serious and dedicated look at the stable and deep seeded stereotypes we take for granted.

The popular representation of cosmological theories can be analyzed like any other narrative, as they create a certain sense of encounter with order and a system on the highest possible levels. Popular cosmology, especially as presented in television programs, articulates the history of the cosmos through comprehensible sequences, which, in actuality, differentiate and clearly display parallel events, which are, at times, very difficult to comprehend. On the other hand, popular cosmology is a narrative like any other, because it transfers different scientific and philosophical traditions on which it is based. More importantly, as its own genre convention, it relies on a worldview that insists on individual responsibility in creating purpose and meaning which we attribute to our own lives, culture and the Universe as a whole. I believe that the way in which popular cosmological literature insists that Man is able to determine his own purpose, and not to expect such determination from god, sacred texts and religious institutions, is what qualifies it as a vital part of a contemporary secular mythology, a cosmogonic myth for the whole modernist discourse of the contemporary world.

Cosmology. As part of astronomy, cosmology entails the study of the structure and evolution of the universe. It studies it's physical properties, chemical makeup, density and speed of expansion, the layout of galaxies and galactic clusters. The purpose of cosmology as a scientific discipline is to help understand everything in universe, from its earliest beginnings, through its evolution to this moment and to the limits of the comprehensible future. Cosmology deals with creating models that define the observed traits of the universe, in an attempt to comprehend why they exist, how they influence us and what our shared future will be like in light of these observations. Thus, cosmology has a clear cosmogonic, but also an eschatological aspect: it considers the very 
beginning of being, but also its eventual end (Ridpat 2007, 241-242; Gleiser 2005; Kragh 2007).

The currently dominant cosmological theory is called the Lambda Cold Dark Matter Model $(\Lambda \mathrm{CDM})$ and it depicts a homogenous universe, which is isotropic and constantly expanding, further sped up by rapid inflation which began moments after the very beginning of existence. The lambda $(\Lambda)$ in the model signifies a cosmological constant or dark energy through which the universe is in a constant state of expansion. Measurements and assessments tell us that the universe is currently made up of $4,9 \%$ of baryonic or ordinary matter, $26,8 \%$ of dark matter, and $68,3 \%$ of dark energy (Grin 2012, 25).

The protoverse, the cosmos in its pre-inflatory phase, contained within it everything we know today: space-time, dimensions, fundamental forces, probably even "laws". It was a perfect singularity, a primordial state wherein everything was contained in "one". It is possible that before that even "nothing" existed. Then, from vacuum fluctuations, matter emerged, and then went through rapid inflation. The question of existence, significance and shape of the laws which governed the emergence of the universe from nothing and its governance before inflation is still a mystery and the subject of philosophical thought.

THE CREATORS OF THE POPULAR COSMOLOGY DISCOURSE. The narrative which comprises contemporary cosmological knowledge is spread over all kinds of media. From traditional popular-scientific literature and newspaper articles, television programs and specialized series, radio shows and films, to websites, blogs and numerous channels on social networks such as You Tube.

Popular-scientific literature which presents contemporary cosmological concepts can be encompass texts written from the emergence and establishment of general relativity, and include books written by the likes of Albert Einstein, Arthur Eddington, Edwin Hubble, Georges Lemaître, Alexander Friedmann, George Gamow, and even Fred Hoyle. However, these books make up a sort of cosmological proto-narrative, as key roles in contemporary 
popular cosmology are taken up by the concepts of inflation, landscape and Multiverse, and these are ideas which were established in the 1980s and 1990s.

Authors such as Alan Guth, Andrei Linde, Paul Steinhardt, Alexander Vilenkin, Andreas Albrecht, Steven Weinberg, Carl Sagan, Stephen Hawking, Paul Davies, Neil Degrasse Tyson, Michio Kaku, Brian Greene, Martin Rees, Lawrence Krauss, Roger Penrose, Neil Turok, Edward Witten, Sean Carroll, Max Tegmark and others are the creators of the contemporary cosmological discourse present in popular culture. Through their papers, popular-scientific books and involvement with different programs, they create and popularize the image of the origin and evolution of the universe, by introducing a large audience to the numerous phenomena and processes that determine the functioning of the world around us.

All of them together, creators of the contemporary cosmological narrative, their predecessors from the $20^{\text {th }}$ century who created the theory of the Big Bang, the founding fathers of modern science from Galileo, Isaac Newton and Johannes Kepler, to Max Planck, Willem de Sitter and Niels Bohr, and even mythic ancestors such as Aristarchus, Eudoxus and Ptolemy, comprise a "scientific tribe" that created its own "myth" (Latour and Woolgar 1986; Latour 1987; Fuller 2006; Bloor 1975; Rosenberg 2005). This myth possesses cosmogonic, cosmological and eschatological segments and depicts the whole story of the cosmos through eons of existence. We are witnessing the process wherein this "myth" is seeping into popular culture and enchanting a wide and varied audience yearning to understand its place in the universe. It is also a multifunctional fractal, establishing relations with other elements of culture.

The integral version of the cosmological narrative can be synthesized from presentations found in the books of Steven Weinberg (Vajnberg 1981), Stephen Hawking (Hoking 2002), Neil Degrasse Tyson (Tajson i Goldsmit 2005), Brian Greene (Grin 2012), Michio Kaku (Kaku 2012), Lawrence Krauss (Kraus 2015), Martin Rees (Rees 1999) and Paul Davies (Davies 1990). Less popular works by the initial authors of inflation theory like Alan Guth (Guth 1997), Andrei Linde (Linde 2009) and Alexander Vilenkin (Vilenkin 
2006) can also be utilized. Aside from literature, of use are video recordings of lectures by significant contemporary cosmologists, as well as their guest spots on educational programs, as well as data and images presented in popular-scientific series produced by numerous global television networks. Series such as Cosmos, Universe, How Universe Works, Through the Wormhole and others are vitally important for the establishment and popularization of the entire discourse. Finally, the production titled Closer to Truth, should be pointed out as a shining example of contemplating the connections between science, philosophy and religion, or rather, culture as such.

NARRATIVE. In order to view cosmology from an anthropological perspective, it is necessary to recall some of the concepts which can contribute to this endeavor. Utilizing them, it is possible to view strict scientific theories as fruits of the labor of human minds, or rather, as stories we tell each other. Because of this, it is necessary to review the concepts of narrative and myth, as well as semiotics, the analytical process which uncovers the intricacies of contemporary cosmological theories and the importance they hold for our culture.

Narratives are a form of representation that focus on the experience of coherency through past time and afford people a sense of order and meaning (Rapport and Overing 2003, 283-284). They transform time into an aspect of socio-cultural reality, because it becomes articulated through sequences in the narration. They order temporal experience by noting and rearranging, outlining and connecting events (Ibid., 284). Folk narratives are embedded in the historical and cultural reality of every community and they convey different traditions that sustain it. They transfer knowledge and beliefs, by standardizing social ethics through nurturing collective memory (Kovačević i Antonijević 2014, 55-57).

Not unlike conventional forms of folklore, popular science understood as any other narrative, expresses the axiological systems and collective values of the society and culture which produces it, regardless of how far positivist science goes in order to 
shield itself from this (Mellor 2003; Lewenstein 1989; Hilgartner 1990; Broks 2006). Like myth, popular science is imbued with a relationship toward man and purpose, a relationship through which a specific image of the world is formed (Малиновски 1971, 89-128; Meletinski 1983, 170-175; Чапо 2008, 170-172).

Popular cosmology is intertwined with philosophical debates framed by the relationship between science and religion, or rather, the dynamics of domination between the processes of secularization and resacralization. It holds a significant position in the culture war between "creationists" and proponents of "secular humanism" which has been raging at the start of the new millennium (Brockelman 1999; Stenger 2012; Drees 2007; Spuhler 1985; Smith 1997). Popular cosmology is also tied to a slew of questions emerging from the philosophy of science, science and technology studies, or rather the scientific war which "escalated" in the mid 1990s (Franklin 1996; Shapin 1996; Kaiser 2007; Martin 1996; Martin 1998; Gould 2000; Mellor 2003). On top of this, the issue of the role of contemporary scientific knowledge in forming a new, potentially transhumanist ideology for the centuries to come is an open one. Tightly intertwined with different spheres and domains of socio-cultural life as it is, the contemporary popular cosmological narrative is worthy of the undivided attention of anthropologists, who must approach it utilizing means developed for making sense of complex narratives. Semiotics, with its tools, affords opportunity for such an undertaking.

MYTH. A myth is defined as a story which, in a given society, is considered a true representation of what took place in the distant past (Малиновски 1971, 89-128; Meletinski 1983, 39-40; Чапо 2008 , 13). According to the structuralist definition, one of the basic tasks of myth is to solve different contradictions which determine social life (Чапо 2008, 267; Levi-Strauss 1989, 213-239; Meletinski 1983, 76-88; Dundes 1997, 40). In order to make sense of contradictions or contradictory interests of different social groups, myth relies on binary oppositions, relations between them and the mediators they create. Actually, myths are sustained by mediators 
and weakened oppositions that create the illusion of solving societal problems.

It is of equal importance that popular cosmology strives to reconcile the contradictions which characterize theoretical cosmology. Through highlighting string theory as an important part of its own discourse, popular cosmology transcends the contradiction between general relativity and quantum mechanics, as two incommensurable concepts. Through string theory, concepts of landscape and Multiverse, popular cosmology offers collateral for further research theoretical and experimental endeavors. By pointing out the inconsistencies of the major theories, popular cosmology infers that the golden age of science is yet to come. Staring into the abyss of our own ignorance makes it easier for us to determine the purpose of existence and our own work.

Terry Eagleton reminds of the widely accepted idea that early myths served as "narrative theories" about the world (Eagleton 1996, 47). They function as "metaphysical systems of knowledge" that explain the origin of man and his enterprises. According to his understanding, even today myths function as an "instinctive strategy" which aids us in understanding or making sense of things (Ibid., 47). Myth is most definitely one of the major mediums of ideology which naturalizes specific interests by incorporating them into its own structure. This trait should be sought in the popular cosmological narrative and the ways in which it is presented to audiences, as it seems certain that it contains numerous sociocultural codes and plays a significant role in a wide variety of conflicts regarding domination in various fields of social action.

It should be pointed out that the way in which cosmology is presented to audiences and the way in which it enters everyday life possess certain narrative and genre characteristics. This points to the fact that contemporary cosmological theories present in popular culture can be analyzed using tools developed for the analysis of folklore (Cawelti 1974, 1-9; Cawelti 1968, 381-390; De Sosir 1989; Chandler 2002; Danesi 2002; Giro 1983, 28; Eko 1973, 12; Lič 2001; Eagleton 1996, 93-94). 
A common trait of both cosmology and mythology is that they shape the world, they introduce order and sense into the chaos of existence. The contemporary cosmological narrative represents the origin and evolution of the universe to a wide audience, by simplifying complex processes and phenomena that strain the imagination and demand the full force of intellectual capacity. More importantly, the cosmological conception belongs to a far more complex discourse with a clear axiological system at its center. It contains specific value codes which contribute to establishing a cultural system, ethos or worldview. The task of anthropological analysis is to uncover and highlight it as such, and as socially relevant.

The contemporary cosmological narrative, like myths and epics, really does systematize knowledge and experience of the world, making it understandable, ordered, predictable and - as much as possible - controllable. In general, we often experience the world as confusing, chaotic and unruly. Myths, like contemporary cosmological theories, contribute to our feeling of certainty, which shapes such a world into a cultivated and bearable environment, an ordered system - the cosmos. Cosmology offers us an image of the universe, and it is upon us to discern whether this image imbues us with a sense of safety or pleasure stemming from our place in it. Simply put, the cosmological narrative has a specific role in considerations about identity and self-understanding of Humanity as a whole, and that qualifies it as an anthropological topic.

THE POPULAR COSMOLOGICAL NARRATIVE AS A FORM OF FOLKLORE. The "folklorized" cosmological narrative can be found as a form of genre convention in popular-science literature. It is always a part of a larger whole, meaning that the rest of the text - or the narration in television programs - focuses on explaining it. Most often, it is told as a myth or other folk tale, through narrative sequences or episodes centering on a certain process or phenomenon. A certain occurrence is presented as a character, a person or a participant of the story, thus gaining importance and value in the narrative as a whole. 
Based on texts by Neil Degrasse Tyson, Michio Kaku and Brian Greene, it is possible to construct an ideal type narrative, a description of the Cosmos from its earliest time to today:

Almost 14 billion years ago, the Cosmos was a speck of matter, space and energy no bigger than a pinhead. All forces, a possibly even time, were combined into one superforce. When the Universe was $10^{-43}$ seconds old, and its temperature was $10^{30}$ degrees, it started to expand and grow. Immediately after that, it entered the phase of inflation, a sudden and exponential expansion, that resulted in the separation of forces. After this, the Universe was still very hot, so photons formed pairs of matter and antimatter particles that annihilated each other. For some unknown reason, the symmetry of these pairs was corrupted, and matter "won". During the first few minutes, matter turned into protons and neutrons and atoms formed. As the temperature continued to drop, hydrogen, helium and lithium formed, and the Universe became transparent. During the first billion years it continued to expand and cool. Galaxies started forming. After almost 7 billion years, the Sun formed, and after that the planets around it. The Earth formed in an orbit which would allow it to form and sustain an atmosphere and liquid oceans in which, a few billion years later anaerobic bacteria will emerge and help establish an oxygen rich atmosphere. After this, the long and slow process of the development of life, the flora and fauna of Earth, took place. Some 65 million years ago, an asteroid destroyed most life on Earth, but this cataclysm created favorable conditions for the surviving mammals to take up empty ecological niches. One of the clades developed into the primate Homo sapiens with a level of intelligence high enough to develop science through which it will succeed in understanding the origin and evolution of the Cosmos.

In the words of Neil Degrasse Tyson:

"Yes, the universe had a beginning. Yes, the universe is still evolving. And yes, we can trace the origin of every atom in our bodies back to the Big Bang, or the thermonuclear furnace inside massive stars. We are not simply in the universe, we are part of it. We were born from it. It could even be said that through us, here in this remote corner, the universe is making sense of 
itself. And we are at the very beginning of this journey."(Tajson i Goldsmit 2005, 19-22).

Cosmology can be viewed as a mythological narrative which deals with the origin of Life, Intelligence and Humans, as a myth that explains their place and significance in the Universe. Like the Oedipus myth, through the cosmological narrative, we contemplate out own rootedness, uniqueness and value in the overall selfobservance of the Cosmos. The popular cosmological narrative also serves as a kind of eschatological myth which offers hope for survival, but guarantees an ultimate end of fathomable existence with the Big Rip. This isn't the only, but it is a very good reason to vie the contemporary popular cosmological narrative from an anthropological perspective as part of a new secular mythology tasked with explaining the real state of affairs in the Universe.

Cosmological theories, and hence the popular cosmological narrative as well, fit the definition of myth because they speak of the earliest beginnings of space, with a justifiable belief that this is true. The description of the first three minutes of the universe, or the Planck era, really does cover the earliest comprehensible time. Furthermore, Planck time is based on experimentally provable terms, so this period is based on theoretical speculation and approximation of a "mythical time". This does not diminish the value of cosmological assumptions. On the contrary, it serves to further celebrate the capability of the human mind to reach, through science, limits that, even a hundred years ago, were beyond its comprehension.

As an expression of the legitimacy of an anthropological, or rather, semiotic view of the cosmological narrative as a form of folklore, the possibility of the narrative's segmentation - the possibility to break it up into key analytic elements - should be pointed out. The basic course of presenting contemporary cosmological theories fits, to a certain extent, the narrative plot (Antonijević 2010,195) which begins with the primordial event, the trouble which marks the beginning of cosmic evolution, or destroys the source equilibrium of forces (Dundes 1986, 41-419). It continues with a series of trials which the universe goes through, creating the necessary conditions for intelligent life to arise. Further 
on, the segment of structure which determines reintegration emerges: the cosmos is shown as capable of self-seeing and selfunderstanding through human intelligence. Ultimately, the contemporary cosmological narrative contains an eschatological segment that tells of the return to perfection, the quantum emptiness of the Big Rip, the product of the influence of dark energy and gravity which will empty the universe as we know it today. This is the "ultimate fate of the universe" as foretold by the $\Lambda$ CDM model.

In other words, the cosmological narrative possesses an initial sequence in which order is destroyed. It is followed by trials the cosmos goes through on the road to forming Life, wherein different polemic and contractual episodes are established. Finally, there is a string of positive episodes in which the Solar system and planet Earth are formed, leading to the evolution of life and the emergence of Humans and Intelligence, but also an eschatological return to the perfection of quantum emptiness, which re-establishes order and balance in the universe. Like the folk stories of American natives which describe the movement from imbalance to a natural equilibrium (Dundes 1986, 418-419), contemporary cosmology follows a similar path from the singularity, the Big Bang and inflation, to the current moment, and the future of the universe in the inescapable quantum void.

The ACTAnTial MODEL. Popular cosmology describes the epic journey of Life and Intelligence, Humans and Civilization through the turmoil of the evolution of the universe. Analyzed as a myth, narrative or text, contemporary cosmology displays a multidimensionality as a cultural artifact, and isn't merely a "sterile" hyper-positivist theory. In contains a multitude of principles which encourage, but also problematize the uniqueness of the emergence of Life and its significance for the "self-awareness" of the cosmos. An anthropological view of popular cosmology as a narrative enables us to determine how meaning is "ascribed" to the endeavor of determining the place of Man in the Universe.

The cosmological narrative can be analyzed using actantial analysis, and the semiotic square devised by Algirdas Greimas. 
These help uncover a number of layers of meaning of the contemporary cosmological narrative in Western culture. According to the actantial structure of the syntaxic organization of a narrative, the plot has six elements: the subject, who wants to attain the object of their desire, the sender that initiates the plot, the receiver that benefits from the plot, the helper that contributes to the achievement of the goal, and the opponent that inhibits the plot (Антонијевић 2010, 191-192; Herbert 2011, 71). Greimas' framework of actants is familiar:

$$
\begin{gathered}
\text { SENDER (D1) } \rightarrow \underset{\uparrow}{\text { OBJECT }(O)} \rightarrow \text { RECEIVER (D2) } \\
\text { HELPER (A) } \rightarrow \text { SUBJECT }(\mathrm{S}) \leftarrow \text { OPPONENT }(\mathrm{P})
\end{gathered}
$$

The narrative which can be synthesized and adapted for analysis is defined by abstract actants, which is in line with Greimas' views. The cosmological narrative is an epic in which Quantum emptiness, or the Universe itself espouses the role of sender, one devoid of intent and conscious tendency, but one which, through the process of narration gains aspects of a teleologically motivated agent. The position of receiver is held by Humans, who, in themselves comprise the reasons and efforts of the Universe. According to the popular cosmological narrative, Humans are the medium through which the Universe gains self-awareness and the capability to understand itself. Still, the positions of subject and object complicate the story, the first is held by Life, while the second is held by Intelligence. The scientific segment of the cosmological "myth" insists on the possibility and significant probability that there are numerous forms of life throughout the Universe, and that a part of them is intelligent, if not significantly more intelligent than humans. Finally, the position of helper is taken up by Time, as an assistant that enables intelligent life, and humans to emerge. It is certain that planet Earth, as the basic condition for the emergence of humans doesn't take up a special place in the Universe, as much as it was there in a satisfactory "historical" moment of its existence, when the conditions were right for the flourishing of culture. Finally, the opponents of the emergence of intelligent life are the Laws of nature which determine the possibility of survival of 
Humans, Life, Intelligence and Civilization. The laws of nature are absolute and the Universe will certainly behave in accordance with them, which will eventually lead to entropy. The actantial model of the popular cosmological narrative can be represented this way:

$$
\text { QUANTUM EMPTINESS (D1) } \rightarrow \underset{\uparrow}{\operatorname{INTELIGENCE}(0) \rightarrow \text { HUMANS (D2) }}
$$

$$
\text { TIME (A) } \rightarrow \text { LIFE (S) } \leftarrow \text { LAWS OF NATURE (P) }
$$

What the popular cosmological narrative tells us is that we are the makers of our own destiny and that we are responsible for our own survival. According to the cosmological narrative, there is hope in the future, but it will require an even stronger and more fruitful Intelligence on the part of Humans, so as to move Life to other places and other times. Among other things, the quest for alien life and a possible encounter with other forms of civilization have their own lace in the narrative, but they do not dominate the plot. In the narrative, alien cultures play the role of affirmation of scientific discoveries which popular cosmology is based on. The search for intelligent life in the Universe and its valorization is at the very end of the popular cosmological narrative.

THE SEMIOTIC SQUARE. Algirdas Greimas adapted the logical square of opposition and posited it as an analysis of truth and lies in a given narrative. The semiotic square implies a thorough classification and analysis of contrary signs, as well as the consideration of interrelationships between dichotomous concepts that form specific relations. The basic premise of the semiotic square is to map logical contrarieties, contradictions and implications connected to key semantic elements in a text.

Greimas' semiotic square represents an expression of his attempt to understand the conditions necessary for the emergence and production of elementary structures of meaning in a narrative (Gremas and Rastier 1968; Greimas, Perron and Collins 1989, 539; Greimas, Courtes and Rengstorf 1976; Antonijević 2010, 197; Herbert 2011). Utilizing the semiotic square enables us to view the dynamics of truth and illusion in any semiotic act, foremost in a text 
(Hebert 2011, 51). The semiotic square maps logical conjunctions and disjunctions in the structure of a story that are deep seeded, abstract and difficult to see, so it can be used to extrapolate binary oppositions and meta-terms through which the articulated meaning of a text is formed (Antonijević 2010,198). It enables the reading of the implicit, latent, hidden or suppressed meaning of a narrative, and the content and semes used to fill it in afford an image of the socio-cultural context of the text (Antonijević, 198-199).

Actantial analysis can be complemented by a series of semiotic squares that enable us to interpret the articulated meaning behind the popular cosmological narrative. The semiotic square can be populated by various semes gleaned from the three narrative levels of the story: the semio-narrative, the deep level and the discursive level. Here only the discursive level will be presented, as it describes the relationship between science and religion which has become a culture war between creationists and scientists interested in the debate such as Sean Carroll, Lawrence Krauss and Richard Dawkins.

At the discursive level, we find the layout of semes dealing with the relationship between science and religion in the contemporary world. The first opposition is between the semes of evolution and creation. The second is between humans and god. Above the first opposition in which the terms are contrarian we can construct the meta-term dogma, as science, like religion, accepts its own axioms, ideas that can't be proven as true, but are considered true none the less. On the other side, on the second semantic axis, made up of terms that contradict the previous, the meta-term of research can be constructed. Religion, like science, forms its own varied research projects, even if they are just attempts at reinterpreting scientific knowledge. Finally, above the deixis made up of the terms evolution and humans, the meta-term science is constructed. Opposing it, above the terms god and creation, the meta-term religion is constructed. Graphically, the semiotic square of the popular cosmological narrative looks like this: 


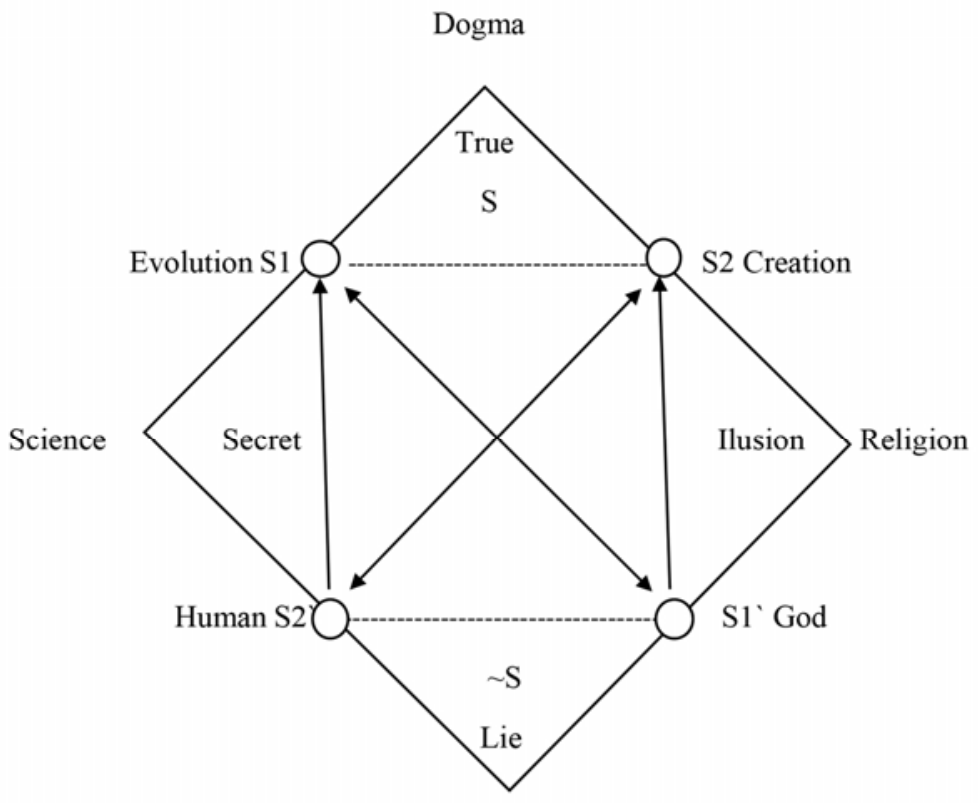

Research

Greimas' semiotic square can be enriched by the veridictory square (Greimas, Courtes and Rengstorf 1976, 439-440; Антонијевић 1991, 179-180). The starting position of the square represents desirable values and "truths", this side of the square represents that which is "secret". It is opposed by the position of undesirable and "false" which is to be overcome, this side of the square represents "illusion", which along with the unacceptable and wrong makes up the deixis of "false". The reading of true, false, secret and illusion depends on the intentions and capabilities of the senders and receivers of information (Herbert 2011, 74-78; Антонијевић 2007, 102-110; Antonijević 2009, 266). 
Popular COSMOLOGY AND THE PHILOSOPHY OF SCIENCE. From Karl Popper a logical positivism, refutability (falsifiability) and problem solving, which authors such as Alan Guth and Paul Steinhardt often recall, Thomas Kuhn and paradigm shifts from the idea of the eternal universe to the idea of a hot Big Bang, to research programmes of Imre Lakatos and the concept of the inflatory cosmos which is searching for proof through more and more experiments, contemporary cosmology well illustrates the dominant flows of philosophical thought in the 20 $0^{\text {th }}$ century (Kaiser 2012; Bloor 1975; Fuller 2006).

The example of the popular cosmological narrative shows the transformation of dominant ideas, conventional science, and new paradigms in the general cosmological theory of the 20th century. The importance of the philosophy of science for contemporary cosmology is best exemplified by the relationship of one of the creators of the concept of the inflatory universe, Paul Steinhardt to his own theoretical work. Namely, Steinhardt is one of the harshest critics of inflation, attempting to refute the idea of the Multiverse, which is one of the most significant consequences of eternal inflation. It is his understanding that the idea of the Multiverse collapses and possibility of prediction by the theory of inflation. In other words, the theory of the Multiverse is not refutable, which robs it of its scientific character according to Karl Popper. Inflation predicts everything, and so, predicts nothing according to Steinhardt. Leaning on Popper, Steinhardt refutes his own theory, by forming an alternative. Along with Neil Turok, Justin Khoury and Burt Ovrut he established the ekpyrotic model of the universe.

Contemporary popular cosmology highlights the importance of the philosophy of science in the contemporary world. It also uncovers the intellectual and clashes about dominant paradigms and positions in scientific discourse. It focuses our attention on science as a political arena of negotiation, refutation and the search for compromise.

Ultimately, popular cosmology is at the center of issues concerning the formation of an educated and active participant in social life in the contemporary world. Should such a person be a devout believer or a harsh critic of religion, science, politics and 
culture? What will be the image of the world in contemporary society built on? Is there room for traditional mythological images, or must we insist on a scientific view of the origins of the universe? What kind of education do we need for the $21^{\text {st }}$ century? The role of popular science in general remains an open topic of conversation. It could be said that its role is to educate a wide audience but it's not always like that. However, in an ideal case, this kind of knowledge should be something audiences gleaned from the school system. It is important to consider the extent to which popular science is part of the entertainment industry, and to what extent it is part of the 250year-old enlightenment project. It is important to understand why audiences find popular cosmology appealing.

ConCLUSION. A text like this one can't adequately present the full breadth and depth of the connections and themes that are intertwined with popular cosmology, but it can point to the possibilities afforded by an anthropological analysis of these relations.

It is important to point out that cosmology makes us face our own responsibility for the ideas of the sense and purpose of existence which we create. These are not found, but created through constant and devoted labor.

Like myths, cosmology doesn't really solve the contradictions it deals with. It just underlines the fact that knowledge keeps eluding us, and teaches us humility in facing our own place in the Universe.

The popularity of television series and popular-science literature in contemporary society tell of the significance that cosmology has for contemporary thought and the culture of the new millennium. Viewed as a form of folklore, or part of a secular mythology, popular cosmology can be understood as part of a system of a new, potentially transhumanistic ideology of a hypermodernist generation being formed right in front of our eyes. 
When viewed as a focal point of a number of other processes and narratives, popular cosmology becomes a cultural artifact of immense anthropological significance. Because of this, I believe it should be analyzed as a multidimensional phenomenon that possesses the potential to transform into various narrative forms that can find their place in strictly scientific, but also philosophical and religious discourses.

\section{References}

Antonijević, Dragana. 2010. Ogledi iz antropologije i semiotike folklora. Beograd: Srpski genealoški centar i Odeljenje za etnologiju i antropologiju Filozofskog fakulteta.

Barnard, Alan and Jonathan Spencer, eds. 2010. The Routledge Encyclopedia of Social and Cultural Anthropology. Oxon-New York: Routledge.

Bloor, David. 1975. "A Philosophical Approach to Science." Social Studies of Science 55 (4):507-517.

Brockelman, Paul. 1999. Cosmology and Creation: The Spiritual Significance of Contemporary Cosmology. New York-Oxford: Oxford University Press.

Broks, Peter. 2006. Understanding Popular Science. Berkshire: Open University Press.

Cawelti, John G. 1969. „The Concept of Formula in the Study of Popular Literature." The Journal of Popular Culture 3 (3):381390.

Cawelti, John G. 1974. "Myth, Symbol and Formula." Journal of Popular Culture 8 (1): 1-9

Chandler, Daniel. 2002. Semiotics for Beginners. London and New York: Routledge.

Craig, William Lane. 2006. “J. Howard Sobel on the 'Kalam' Cosmological Argument". Canadian Journal of Philosophy 36 (4): 565-584.

Чапо, Ерик. 2008. Теорија митологије. Београд: Clio. 
Danesi, Marcel. 2002. Understanding Media Semiotics. London: Arnold.

Davies, Paul. 1990. God and the New Physics. London: Penguin Books.

De Sosir, Ferdinand. 1989. Opšta lingvistika. Beograd: Nolit.

Drees, Willem B. 2007. "Cosmology as Contact between Science and Theology." Revista Portugesa de Filosofia 63 (1/3): 533-553.

Dundes, Alan. 1986. "Structural Typology in North American Indian Folktales." Journal of Anthropological Research 42 (3): 417426.

Dundes, Alan. 1997. "Binary Opposition in Myth: The Propp/LeviStrauss Debate in Retrospect." Western Folklore 56 (1): 39-50.

Eagleton, Terry. 1996. Literary Theory: An Introduction. Oxford: Blackwell Publishing.

Eko, Umberto. 1983. Kultura. Informacija. Komunikacija. Beograd: Nolit.

Franklin, Sarah. 1996. "Making Transparencies: Seeing through the Science Wars." Social Text 46/47: 141-155.

Fuller, Steve. 2006. "A Step toward the Legalization of Science Studies." Social Studies of Science 36 (6): 827-834.

Giro, Pjer. 1983. Semiologija. Beograd: Prosveta.

Gleiser, Marcelo. 2005. The Dancing Universe: From Creation Myths to the Big Bang. Hanover-New Hampshire: Dartmouth College Press.

Gould, Stephen Jay. 2000. "Deconstructing the 'Science Wars' by Reconstructing an Old Mold." Science 287 (5451): 253-261.

Greimas, A. J. and Francois Rastier. 1968. "The Interaction of Semiotics Constraints." Yale French Studies 41: 86-105.

Greimas, Algirdas Julien. Paul Ricoeur, Paul Perron and Frank Collins. 1989. "On Narrativity." New Literary History 20 (3): 551-562. 
Greimas, Algirdas Julien. Paul Perron and Frenk Collins. 1989. “On Meaning." New Literary History 20 (3): 539-550.

Grin, Brajan. 2012. Skrivena stvarnost - Paralelni univerzumi i duboki zakoni kosmosa. Smederevo: Heliks.

Guth, Alan H. 1997. The Inflatory Universe: The Quest for a New Theory of Cosmic Origins. Reading, Massachusetts: Helix Books.

Hackett, Edward J., Olga Amsterdamska, Michael Lynch, Judy Wajcman. 2008. The Handbook of Science and Technology Studies. Cambridge-London: The MIT Press.

Herbert, Louis. 2011. Tools for Text and Image Analysis: An Introduction to Applied Semiotics. Accessed 16.03.2018. http://www.signosemio.com/documents/Louis-HebertTools-for-Texts-and-Images.pdf

Hilgartner, Stephen. 1997. "The Sokal Affair in Context." Science, Technology \& Human Values 22 (4): 506-522.

Hoking, Stiven. 2002. Kratka povest vremena. Beograd: Alnari.

Kaiser, David. 2007. "The Other Evolution Wars: Creationists have long battled with geologists and biologists, but they have only lately taken on physicists and cosmologists." American Scientists 95 (6): 518-525.

Kaiser, David. 2012. How the Hippies Saved Physics: Science, Counterculture, and the Quantum Revival. New York: W. W. Norton \& Company.

Kaku, Mičio. 2012. Paralelni svetovi - Putovanje kroz postanak, više dimenzije i budućnost kosmosa. Smederevo: Heliks.

Kovačević, Ivan i Dragana Antonijević. 2014. Traženje značenja: Eseji iz antropologije $i$ folkloristike. Beograd: Srpski genealoški centar.

Kraus, Lorens M. 2015. Čitav svemir ni iz čega - Zašto postoji nešto a ne ništa. Beograd: McMillan. 
Kragh, Helge S. 2007. Conceptions of Cosmos - From Myths to the Accelerating Universe: A History of Cosmology. Oxford and New York: Oxford University Press.

Latour, Bruno and Steve Woolgar. 1986. Laboratory Life - The Construction of Scientific Facts. Princeton New Jersey: Princeton University Press.

Latour, Bruno. 1987. Science in Action: How to Follow Scientists and Engineers through Society. Cambridge: Harvard University Press.

Levi-Strauss, Claude. 1989. Strukturalna antropologija. Zagreb: Stvarnost.

Lewenstein, Bruce V. 1987. "Was there really a Popular Science 'Boom'?" Science, Technology \& Human Values 12 (2): 29-41.

Linde, Andrej. 2009. Fizika čestica i inflatorna kosmologija. Novi Sad: Akademska knjiga i Institut za fiziku Beograd.

Lič, Edmund. 2002. Kultura i komunikacija: Logika povezivanja simbola - Uvod u primenu strukturalističke analize u socijalnoj antropologiji. Beograd: Biblioteka XX vek.

Малиновски, Бронислав. 1971. Магија, наука и религија и друге студије. Београд: Просвета.

Martin, Emily. 1996. "Meeting Polemics with Irenics in the Science Wars." Social Text 46/47: 43-60.

Martin, Emily. 1998. "Anthropology and Cultural Study of Science." Science, Technology \& Human Values 23 (1): 24-44.

Meletinski, E. M. 1982. Poetika mita. Beograd: Nolit.

Mellor, Felicity. 2003. "Between Fact and Fiction: Demarcating Science from Non-Science in Popular Physics Books." Social Studies of Science 33 (4): 509-538.

Rapport, Nigel and Joanna Overing. 2003. Social and Cultural Anthropology: The Key Concepts. London and New York: Routledge. 
Rees, Martin. 1999. Just Six numbers: The Deep Forces That Shape the Universe. London: Weidenfeld and Nicolson.

Ridpat, Jan. 2007. Veliki rečnik astronomije. Beograd: Dereta.

Rosenberg, Alex. 2005. Philosophy of Science: A contemporary introduction. New York and London: Routledge.

Shapin, Steven. 1995. "Here and Everywhere: Sociology of Scientific Knowledge." Annual Review of Sociology 21: 289-321.

Синђелић, Светозар. 2005. Релативност научне рационалности. Београд: Институт за филозофију Филозофског факултета.

Smith, Quentin. 1997. "Quantum Cosmology`s Implication of Atheism." Analysis 57 (4): 295-304.

Spuhler, James N. 1985. "Anthropology, Evolution and 'Scientific Creationism'." Annual Review of Anthropology 14: 103-133.

Stenger, Victor J. 2012. God and the Folly of Faith: The Incompatibility of Science and Religion. New York: Prometheus Books.

Tajson, Nil de Gras i Donald Goldsmit. 2005. Nastanci - Četrnaest milijardi godina kosmičke evolucije. Beograd: Laguna.

Vajnberg, Stiven. 1981. Prva tri minuta. Beograd: Vuk Karadžić.

Vilenkin, Alex. 2006. Many Worlds in One: The Search for Other Universes. New York: Hill and Wang. 



\section{Ritual Kinship in SOME CALENDAR CELEBRATions A CASE STUDY OF THE CELEBRATION OF EPIPHANY IN MACEDONIA}

Ritual kinship represented through godfatherhood is portrayed in religious celebrations and cultural events that take place on the holiday of "St. John's Godfatherhood", or commonly known as the Epiphany "Vodici". Pierre Bourdieu's theory of practice shall be taken into consideration. In terms of perspectives on kinship research, primarily in Macedonian ethnology and anthropology, the use of ritual kinship can be perceived with its multifunctional meanings. It can be seen as actualization (reactualization); as popularization in contemporary times; as protection or preservation of intangible cultural heritage; as a cultural memory and representation of the past through religious celebrations and cultural events that are associated with identity, but also encompassing the various ways of comprehension and interpretation of this kind of kinship associated with celebrations, depending on the "symbolic capital" that the participants in these festivities possess.

Key words: ritual kinship, godfatherhood, Macedonia, calendar celebrations, Vodici, cultural evenets

INTRODUCTION. The term kinship implies culturally defined relations between individuals that are usually established through family ties, though links can be established on other grounds. Thus, anthropology revised a multitude of concepts and categories regarding the studies of kinship and social relations during the second half of the $20^{\text {th }}$ and the $21^{\text {st }}$ century as well (see examples of: Segalen, 1997, 31; Segalen, 1998, 26; Segalen, 2009, 66-67; Ivanović, 2008, 107-138; Ivanović, 2008a, 88-116; Carsten, 2004). In that sense, cultural anthropology used the term fictive kinship until the middle of the late $20^{\text {th }}$ century, to express what is not real, 
as opposed to real kinship to express the blood and marriage relations. ${ }^{1}$ In sociology of families, this term as well as the term chosen kinship, was used to denote relations established through religious rituals, close friendly ties and other essential, reciprocal, social and economic relations. Examples of fictive kinship are godfatherhood, adoption and close friendly relations. David Schneider has a key role in reformulation of kinship studies in anthropology (Carsten, 2004,18) and he establishes that the relations by blood as basis is not universal for kinship relations and that it can be a culturally specific symbol of kinship only in specific cultures. The central topic of Schneider's two key books - American kinship (1980/19682) and A Critique of the Study of Kinship (19843) was the relation between nature and culture or between biological and cultural aspects of kinship (Carsten 2004, 19). On one hand, Schneider's work stirred doubts that kinship studies are futureless, but on the other hand, focusing on culture as a symbolic system, it is obvious that he sets the ground for new traditions of kinship studies (Carsten, 2004:20). This means that the explanations of anthropologists are no longer directed towards the functioning of the social whole, but towards the interpretation of the cultural diversity and understanding of meanings.

Kinship researchers believe that the ways people in different cultures differentiate between what can be denoted biological and what sociological should be specified, as well as the points in which members of different cultures make those distinctions, which, without any prejudice, should be the heart of the comparative analysis of kinship (Carsten 2004,189). They use his words and suggest new ways of comprehension of kinship (Carsten 2004,19), so in that sense, Carsten talks about "relatedness" and about

1 Fictive Kinship. http://family.jrank.org/pages/630/Fictive-Kinship. html; Charles, A. Ibsen \& Patricia Klobus, 1972. Ficitve kin term use and social relationships: Alternative interpretations. Journal of marriage and the family. November, 1972.

2 Schneider, David 1980. American Kinship: A Cultural Account, 2nd edition. Chicago, IL: University of Chicago Press.

${ }^{3}$ Schneider, David 1984. A Crituque of the Study of Kinship. Ann Arbor, MI: University of Mitchigen Press. 
"cultures of relatedness", i.e. what is the link that ties people (Carsten 1995, 224; Cultures of relatedness, 2000). In short, we can say that in the last quarter of the $20^{\text {th }}$ century, the critique of the structuralist paradigm of kinship comes from different theory centers (structural - Marxism, theory of practice, feminist and historical analysis, symbolic anthropology and cultural analysis of meanings (Ivanović 2008, 111).

The kinship that is not based on blood relations and kinship by marriage will be the subject of this paper. This kinship is known as spiritual or as we have already mentioned - a fictive kinship, but ritual kinship is the term that is also associated with it, because privileged social relations are established by ritual. Godfatherhood, blood-brotherhood and blood-sisterhood are established through a ritual.

Godfatherhood 4 had an important place in the life of people that can be followed on the level of an individual, family (baptisms and weddings) and the peasant community, through which the spiritual kinship of the community was identified. The latter was best expressed through St. John's godfatherhood (Петреска 2002, 39). The emphasis would be on celebrating Epiphany or St. John's godfatherhood, celebration that in Skopje and Ohrid has transformed into a cultural event where godfatherhood as well as

${ }^{4}$ Godfatherhood is considered to be of pre-Christian origin and in Christianity, the institution of "godfatherhood" is not only recognized but also more strengthened and there is even a ban dating back from the $6^{\text {th }}$ century that bans marriage between spiritual relatives (Гуди 2005, 47, 50-51; Mitterauer, 2005: 95; Bandić 1980, 367-368; Петреска, 2005:108-110). А large number of researches emphasize the social dimension of the ritual/spiritual or symbolic kinship that is significantly developed in the Mediterranean, Latin American and South Slavic world, regarding the establishment of friendship nets between individuals and families with approximately equal social status for protection and solidarity that were of essential necessity for securing additional safety of the kinship group, mainly in societies that do not show trust in the public institutions. (Hammel 1968, 5354; Ракић 1972, 107, 114; Генчев 1974, XVI:100-101; Bandić 1980, 376; Kazer, 2002, 265-270; Čapo-Žmegac 2001,530, 541, Джордано, 2006, 194195). 
the term godfather has an important role. ${ }^{5}$ Efforts will be made to include Bourdieu's theory of practice, focused on the study of the use of relationships in practice, that is to say that practice is the result of a specific habitus and capital which is not solely economic but also cultural and symbolic. These forms of capital can easily be transformed into economic, just as the economic capital can easily be turned into cultural and symbolic capital. Habitus is a product of the process of implantation and appropriation of objective structures (for e.g. language, economics, etc.), necessary for the production of collective history that reproduces, in the shape of permanent dispositions, with every individual of a given group or class that is continuously exposed to the same conditions or set into the same material conditions of existence (Bourdije 1999, 169-170; Pajević in: Bourdije 1999, 249). According to Bourdieu, since the history of the individual is only a kind of description of the collective

5The godfatherhood and the term godfather can be seen in many events taking place in Macedonia. For example, at the end of the 1990s, the sole gastronomical events featuring gjomleze (a kind of pie), chestnuts, etc., had godfathers. (Sее Ковачевић 2007,1091-53 for all gastronomical traditions that are in fact invented traditions); in the early years of the $21^{\text {st }}$ century - around the years 2005-2006, people started celebrating the religious holiday of St. Nicholas which falls on the $18^{\text {th }}$ December according to the new calendar and that turned into a public celebration in the city of Prilep, and in this case it is an invented tradition, and every year one of Prilep's companies takes over the role of the event's godfather (http://www.utrinski.mk/?ItemID=FE6CA572BCBF9 5499E80EF8FF83D770E17.12.2013, 16:17; Last seen in October 2016). The function of godfatherhood is also present in some cultural wedding events, where he takes part in the wedding ceremony in the church (Петреска 2017, 89). The godfatherhood, especially the term godfather is still actualized in modern weddings and baptisms, not only in Macedonia but was and still can be seen in other South Slavic countries (see examples by: Златановић 2000, 226; Гребенарова 2000, 92). During the socialist period, due to the social and economic as well as political reasons, including the migration processes, the role of the godfather gradually diminished, or we can say that choosing the godfather inherited with generations, gradually decreased, and the choice based on friendship increased, and in this case we can speak of a symbolic kinship. Aside from this kind of godfatherhood, it is specifically emphasized in modern Christmas Eve celebration when fires are lit and a godfather is chosen. Choosing a godfather is also found at village celebrations of a patron saint's day. (Неделковски 2017, 91-112; Zlatanović 2014,142). 
history of his group or class, the individual systems of dispositions show structural variants of the group or the class habitus that are systematically organized (Bourdije 1999, 171).

Taking into account that social life almost always includes procedures and behaviours undertaken from interest and the factors that are at the same time material and symbolic, Bourdieu points out that non-economic (social, cultural, ritual) practices can represent values, symbolic, and social capital that can be transformed into economic capital (Bourdije 1999, 213-216; Ivanović, 2008, 117-118). At the same time, the existence of longlasting structures should not be neglected. Therefore, the understanding that anthropological analysis must take into account everyday practices and relatively rapid changes alongside with the study of long-lasting structures and systems of values that prevail (Ivanović 2008a, 115).

Starting from the enhanced interest in traditional culture and folklore heritage, or the increased scientific interest in the study of folklore as intangible cultural heritage, space is created for the use of tradition or return to tradition, cultural memory or representation of tradition. In this sense, the ritual kinship shown in the celebrations and the cultural events of Epiphany in Skopje and Ohrid are reviewed.

Sources of my research include written sources of traditional celebrations of the holiday of Epiphany; my field research of celebrations of Epiphany in several places in Macedonia; my personal participation and observation of the celebrations at Epiphany, mainly in Skopje which as the ones in Ohrid have grown into cultural events; then there are written and electronic media that are particularly vocal in reporting the celebration of certain holidays, mainly of religious character and have an immense influence of the representation of tradition.

ST. JOHN'S GODFATHERHOOD - "EPIPHANY" (VODICI). Epiphany is associated with the Christian holiday celebrating the theophany of Christ and his baptism in the river of Jordan by John the Baptist on $19^{\text {th }}$ January and the next day is St. John the Baptist Day 20th January 
which in certain regions of Macedonia is also known as the female Epiphany. Epiphany celebrations, especially the ones in Skopje and Ohrid that have grown into cultural events are covered by the media. What media cover the most and what symbolizes the holiday today, which for the Orthodox Christian is a non-working day, ${ }^{6}$ is the walk around the church, i.e. procession with crosses and icons, the priest throwing the cross into water (a river, lake or a pool) and retrieving the cross from the water by young men.

The one that catches the cross will be the godfather during the next year and he mostly receives tangible gifts. He is believed to have the best of health during the whole year (Петреска 2014,107). This kind of celebrations started in Skopje, where the archbishop of the Macedonian Orthodox Church (MOC) throws the cross from the Stone Bridge into the Vardar river; in Ohrid and today the media broadcast the throwing and retrieving of the in almost every place (Петреска 2014, 107). The celebration of Epiphany can be interpreted as revealing the identity, which aside from local, can also be seen as the national identity of Macedonians, because such celebrations are performed all around Macedonia.

Very often in contemporary rituality, as well as during various celebrations, those elements that had an exceptional importance for the community in the traditional culture and have now risen to the level of national culture are accepted, regardless whether they are of collective or family character. In this sense, concerning the Macedonians, I would emphasize the godfatherhood, especially celebrations of the day of St. John or commonly known as Epiphany, or St. John's Godfatherhood (19th January, new calendar). Professor K. Penushliski (Ph.D) concluded that the songs sung at Epiphany (that are constituent part of the rituals, my note) don't exist among other South Slavic peoples, or are not as widespread as they are in certain parts of Macedonia (Пенушлиски 1988 2, 11). In order for a clearer perception to be gained, I will summarize the characteristics of the traditional celebrations of Epiphany in different parts of Macedonia.

\section{$18 / 07$.}

${ }^{6}$ Law on Holidays in Republic of Macedonia, Official Gazette of RM, no. 
This holiday was immensely important in the ritual calendar of Macedonians, in parts of western and southwestern Macedonia, where in many places (e.g. Debarca) it was the most important and the biggest holiday of the year, even more celebrated than Christmas and Easter (Цеалкоски 1984, 93). The Epiphany customs and songs actively persisted in the area of Kopachka, Malesija in Struga, Zeleznik, the area of Prilep, Reka, Mariovo, the area of Skopje (Целакоски 1984, 118). There is one godfather chosen per neighborhood, minding the order of the households or families, where every household takes their turn in taking the role of a godfather. These kinds of godfatherhood are known as godfatherhoods or brotherhoods, "companies” („компании“ or „кумпании“), “crosses” („крстои“, „корстои“). In many places in Macedonia, the organizational and financial preparations of the godfathers and their families lasted for a year. In certain places choosing St. John's godfather starts on Vasilica (14th January), in some places on Epiphany and in some places (e.g. in the village of Bitushe) the godfather choosing celebrations start on January $31^{\text {st }}$ St. Athanas' Day when the new godfathers officially declare in front of the church that they are going "to take the cross" next year (Паликрушева 1975, 65; Ренкас 2013, 185). The godfathers have to prepare lunch and dinner for the whole village; in some places that is done by the old godfathers, in others by both the old and the new ones. The day before the holiday, the godfathers go to church where they leave the crosses overnight in barrels of water and take them out early in the morning on the holiday and adorn them with basil and red thread (Атанасовска, Боцев 1992, 98-107; Петреска 2014,108-109). The villagers start for the church and along with the godfathers and the priest, they perform the procession with crosses and icons, which is actually a tour of the villages, and after that they go to the village river where they hold mass, pray and throw the cross in the river. Young boys jump after the cross and the one who retrieves it, tours the village and receives money. Part of that money is for the boy, and part of it goes to the church, or in some villages the priest gives money to the young man that catches the cross (Целакоски 1984, 95-96, 115,116; Китевски 1982, 19-21; Домазетовски 1975, 253-261; Петреска 2014,109). 
Unlike the western and southwestern part of Macedonia, in the northeast and eastern part of Macedonia, Epiphany has an important part in the ritual calendar, though not as much as some areas of western Macedonia (Малинов 2006,115-118), which speaks about the different cultural traditions. Here an important part is the consecration of the waters after a period of unbaptized days, especially in the larger villages, where mass is held. After the priest performs the service, he "throws" the cross in the water (river, pond, basin or cauldron) and some of the participants, mainly young men get into the water, to "catch" the cross, which is in fact the culmination of the ritual. The one who catches the cross is believed to be "happy and healthy" throughout the year and an award is given to him too. Later, he tours the houses in the area and the people give him food or money as reward. After that the cross is given to the man that bids the greatest sum of money and he then becomes the "godfather of the cross" until the next Epiphany (Малинов 2006, 1151-18).

RESEARCH RESULTS. In the short descriptive material regarding the Epiphany celebrations, one of the most important elements in traditional and contemporary celebrations is the choosing of the godfathers, the crosses and icons procession of the participants of the ritual together with the godfathers, which is actually a tour of the villages and coming to a body of water (a river, lake or pool), throwing the cross in the water by a priest and getting it from the water by young men (Петреска 2014,109). What strikes as curious in the public discourse shown by the people that celebrate this holiday, the MOC and the media is the term godfather and according to Christianity, the holy baptism of Jesus Christ by St. John the Baptist, which implies that St. John is the godfather. "Epiphany" the holy baptism of Jesus Christ by St. John, or St. John's godfatherhood can be associated with Connerton's perception of social memory expressed through ritual performances, through which the community is being reminded of its identity, but what is of paramount importance is that this memory and performance are seen as a "habit-memory", on which philosophers have not spent lots of attention, but which is of extreme importance because the 
participants cannot simply perform unless they are fully into their roles (Connerton 1989, 34-40; 70-71). In Christian memory, memorizing Jesus is a focal point where through the liturgical year (Goff 2007, 125), sequences of his life are being chosen. In the case with the holiday of Epiphany that is Jesus' baptism in the river Jordan by St. John the Baptist, the appearance of the Holy Trinity (Ренкас 2013, 180). St. John takes the place of the godfather. G. Palikrusheva points out that the godfather is believed to be a direct representative of God, that is to say St. John is his representative which can clearly be seen from a song sung at Epiphany that goes: "Hey godfather, godfather, St. John, don't be afraid, be happy!" (Паликрушева 1975, 65) or "Welcome St. John / All the best to you, new godfather / Don't be afraid, be happy..." (Ренкас 2013, 185186). The fact that the godfather is equally associated with St. John is shown in the case where the people of Zeleznik having been given a prayer in church are called "St. Johns” („светијони“ or „светијоани“) (Паликрушева, 1975, 65), or there are cases where in many peasant communities the godfather is called St. John (Шапкарев, 1976, IV,128; Целакоски, 1984,105); in Poreche, the Epiphany's godfather was named "God father" („божикум“) (Ристовски 1970, 133-134; Величковска 2008, 30); in Debarca, all the men from one godfatherhood (v. Slivovo) or one company called each other "My brother, St. John", "bloodbrother", etc. during the holiday of Epiphany (Целакоски 1984, 111; Китевски 1982, 13, 35), which means that the kinship along this line had a special treatment. An example that the godfatherhood has the value of consanguinity, also accepted by Christianity, can be seen through a typical case observed in the area of Debarca, where the law of exogamy exists, which means that marital relations in the frames of the same godfatherhood or company are not allowed (Kitevski 1982,13, 35).

A confirmation of the importance of the holiday and the godfatherhood of "Epiphany" is the fact that they delightfully wait for their turn, for their family to take the role of godfathers. In this case we can say that the Epiphany, as well as the godfather, the godfatherhood for a part of the population is "symbolic capital". According to P. Connerton, the objects that possess symbolic capital are seen in the whole history of life thus possessing memories 
(Connerton 1989, 87). This can be confirmed by the fact that in certain communities where Epiphany was one of the major holidays (eg. in the village of Bituse) "the village does not remember that anyone avoided the holiday of Epiphany, even the poorest people were involved" (Поповски 1975, 251), and the newest research about the same village point out the same, which is supported by the belief that the one that gives up on the role of a godfather shall be punished (with death, illness, etc.) by St. John. "In that village about 3-4 households gave up the godfatherhood and people believe that all bad things that have happened to them later were consequences of giving up" (Атанасовска, Боцев 1992, 99). There is a datum about Drimkol, which is in the region of Struga (v. Jablanica), that some families sold parts of their estate in order not to give up on the godfatherhood because the expenses for the feasts were immensely high, but there were cases when a godfather gave up his role (Домазетовски 1975, 254). In this context, we can point out the case of the village in the area of Debarca (v. Brezani) where this holiday is of utmost importance and that had given up on celebrating this holiday because a widow got married to a man from the same company, thus breaking the exogamic rules of the region (Китевски 1982a, 213). Recent researches of J.Renkas of Epiphany in the village of Bitushe showed her that: The godfather acquires the respect of the people, the financial expenses, the persistent and excellent preparations, the way the guests were met - everything was calculated and summarized. "There was a dialog and rivalry between the godfathers - who was better, who had the affection of the village, who was better prepared" (Ренкас 2013, 188). Examples clearly show that this was also a question of prestige, ties between the families and their reputation. We can categorize this as features of symbolic capital (Bourdije 1999, 206) that is deeply imprinted in the habitus of the community which can also be seen as a longlasting structure.

We have already mentioned that the meaning of the term "godfather" is found in the celebrations of Epiphany that started taking place around Macedonia and which turned into cultural and 
religious events in Skopje and Ohrid7. This term can be found with other cultural events that are not the topic of review. The role is assigned to the one that helps the organization of the event ${ }^{8}$, or has caught the cross on Epiphany.

We can agree with the authoresses Kelemen and Škrbić Alempijević, that festivals - but here I would also add - the festivities, offer possibilities for a multitude of narrations and practices with which different ideas and interpretations of the sole event are shaped and expressed, but also a very wide context inside which they take place (Kelemen and Škrbić Alempijević 2012,11). As one of the goals in the discourses of celebrations and cultural events with themes of religious festivities, where the central role is the godfather, it is unquestionably the origin of the community and its identity. In this case, the discourses of ritual practices are concerned, the ones that tell us about the past, which can be connected with cultural memory and selection of elements from the past desired to be shown. In regard to identity, it can be shown as: local, regional and national. In reviewed festivities and cultural events about Epiphany that use godfatherhood, the thematic association with the past is seen in their presentation. The performers usually show elements from ritual folklore characteristic of a certain time from the past of the community, but which may not be important components in its contemporary identity. The construction of social memory is a process with which the members of a distinctive social group out of the multitude of historical events choose certain fragments, reinterpret them in accordance with the actual social and political contexts and turn them into basis for construction of the group identity. Other historical episodes become places for social oblivion and are

${ }^{7}$ Cultural events or festivals are not the subject of review. See more about them: Петровска-Кузманова, Катерина 2017; Пейчева, Лозанка 2008; Petra Kelemen and NevenaŠkrbić-Alempijević 2012.

8The church and public event in honor of Epiphany in Ohrid has not had a godfather for about three years, and the organization has been overtaken by the local self-management. http://www.ohridnews.com/vesti/111837. (18.01.2018. (Last seen on 11.10.2018). 
deliberately wiped out from the memory of the group (ŠrbićAlempijević 2012, 187-188). In this sense, the phrase places of memory can be understood in the sense used by Pierre Nora: these are not sites, but any significant occurrence of tangible and intangible nature. He also adds the cultural practices such as commemoration, festivals, celebrations, religious celebrations, rituals etc., where memories materialize and are represented as an important factor of group identity (Nora 1989, 12,19). As one of the chosen ritual practices, that has the role of an identity symbol, is the ritual kinship shown through the godfatherhood on Epiphany. We can say that tradition or cultural heritage is a constructed process of cultural memory / remembering or forgetting and that at their make or construction the habitus practices of everyday experience are taken into consideration and they shape them into a kind of a symbolic capital (Albvaš 1999, 79; Nikočević 2013, 335; Bendix 2007, 8-9). This is consistent with Connerton's understanding of remembering through styled performance of ritualized plays that are of utmost importance because the participants cannot simply do the performance or participate in a celebration unless they are not into their roles (Connerton 1989, 34-40; 70-71; Connerton 2004, $36,60)$. In this sense we can say that the actors empathize with the chosen ritual practices in the festivities and cultural events, which means that they also had great significance for the community.

The holiday of Epiphany being mainly associated with its agrarian character can also be perceived as cultural memory associated with identity and a way of communication with tradition and preservation or protection of a cultural good (ПетровскаКузманова, 2017, 182). Given the fact that the celebrations of Epiphany started all over Macedonia but this holiday did not have equal importance, it is implied that different cultural traditions are present. But along with the execution of customs, there are innovations. But to what extent will the custom or cultural goods and innovations be accepted depends on the people i.e. from the audience, which means that if the community likes them, they will be performed, and thus become a common cultural good, and if they disapprove of it, it will be lost along with the creator (Jelinčič, Žuvela Bušnja 2008, 58-59 according to: Burke 1991, 98). If that particular cultural good did not have a high position in its habitus 
memory and if the community did not identify with it, it was harder for it to be accepted. However, there are the different perceptions, interpretations and practices. Bourdieu is of the opinion that customs are one of the most outstanding products of habitus, in which it is possible to observe the sharing of patterns (models) that allow the unharnessing of an unlimited number of practices adapted to new situations, without creating explicit principles (Bourdije 1999, 189). In the case of Epiphany, about which once more we emphasize the different cultural traditions in different parts of Macedonia and that it did not have equal importance and taking into consideration the great number of participants in the ritual - "the catching of the cross" and rewarding the one who caught it, the reasons for their participation can be various. In the public discourse shown by the MOC and media we can say that the act of Jesus' baptism in the river Jordan has an important place, as well as the appearance of the Holy Trinity - God - the father, God - the son and the Holy Ghost, the sanctification of the waters and culmination - the throwing and the catching of the cross by young men including the reward for the one that catches the cross. The stories of the participants in the ritual mostly follow the traditional pattern - that they do it out of faith in God, that the waters are sanctified then and that they have healing power, which is proven by the fact that people take water on Epiphany and keep it throughout the year and drink it in times of illness or wash themselves with it. But, the behaviour of some participants says that their intentions were something different - for example - the reward, with which the holiday for them has a profane form and they participate for fun, etc. ${ }^{9}$

9Improper behaviour of some of the participants (insufficient patience at the mass, forceful taking of the cross from the one that caught it, or taking the cross from a female, groups of boys visiting houses with the allegedly caught cross in order to get gifts from the residents - this happening mainly in those places where this was practiced, etc.) was the reason that in 2014 The Macedonian Orthodox Church announced that the next celebrations of the Epiphany would exclude traditional gifts, with the exception of the cross. On the other hand, many of the participants that do not jump into the water to catch the cross, regularly get into the water believing that the waters are holy and will preserve their health (Петреска 2014, 112-113). 
We can see the different understanding of tradition in modern times or its representation if we consider that organizers, performers and audience are involved in its execution. Here, we can accept Geertz's opinion shared in 1970s about the different understanding and different interpretations. This opens up the question of authenticity, the authenticity of performance and here I accept the opinion of I. Lozica that authenticity must be perceived in a wider social context (Lozica 2008, 241-242). This is confirmed with the accepted opinions that change of tradition does not imply it is dying, but on the contrary - that it lives (Lozica 2008, 248, according to: Yanos Hont; Bauzinger 2002, 200) i.e. that it can survive only if new modalities of existence in changed conditions or the interpretation should be adjusted to the new time.

Inevitably, showing the identity and the protection of the cultural heritage involves the tourist-commercial functions of the folklore and its determined elements can appear as a symbol of identity of a particular region (Bausinger 2002, 177; Bošković-Stully $1971,165-186)$. Bourdieu's theory of practice is right that the social life almost always includes procedures and behaviours led by interest and factors that are simultaneously both material and symbolic, emphasizing that non-economic (social, cultural and ritual) practices can represent value and that the symbolic and social capital can be transformed into economic capital (Bourdije 1999, 213-216). That "symbolic, cultural capital" can be turned into economic capital and folklore and cultural, folklore events and festivals serve as a tool for affirmation of identity and increase of tourist offers, thus increasing the number of tourists are some of the opinions resulting from contemporary research. Namely, they are perceived as markers in social and cultural life that increasingly mark modern tourist experience and because of that prominent role we can talk about festival tourism (Kelemen i Škrbić Alempijević 2012, 51, 54). The cultural event on Epiphany in Ohrid has such a role, where from the media we can see the preparedness of the city to accommodate a sufficient number of tourists. ${ }^{10}$ In this case we

10 https://mk.voanews.com/a/macedonia-vodici/4215319.html (Ohrid embraces Epiphany customs this year. The tourist demand for Ohrid is on 
can say that packing the branded identity - cultural good as a commercial product, (Пейчева 2008, 232) these events help develop the cultural tourism. We must mention that the globalization policies open up the issue of glocalization, which opens up a possibility for promotion of cultural traditions of countries. In that sense the cultural policies of the countries are directed towards presentation, promotion and use of cultural traditions where aside from identity, acquiring capital is inevitable (Bendix 2013, 368-369). But the author emphasizes that the desired economic gain does not offer a sufficient explanation why certain events persist through the ages; she undertook more detailed research of the motivations and the choice of the founders, performers and the general public of the cultural events and they showed her that they are directed towards the affirmation of the local and national cultural identity (cited according to Kelemen i Škrbić Alempijević 2012, 67-68).

CONCLUSION. Attempts have been made for review of the ritual kinship during Epiphany, and the cultural events that are held on Epiphany in Skopje and Ohrid, where the term "godfather" is met. Also, this term can be found at other celebrations or cultural events. Ritual kinship associated with celebrating Epiphany, can be seen as repeated actualization, as popularization in contemporary times, as protection or preservation of intangible cultural heritage; as a cultural memory and representation of the past which is associated with identity, as with most ways of comprehension and interpretation of this kinship associated with celebrations. The ways of comprehension and interpretations depend on the "symbolic capital" carried by the participants in the festivities. If the habitus of

the raise on the 20th January, which is the day after Epiphany, and it is known as the Fishermen's Day. On this day the fishermen take their traditional swim with which in the past it marked the end of the ban for Ohrid trout fishing during its winter spawn, and fish stew is prepared for the visitors.There will be several barrels of wine out of which one with red wine. The person who caught the cross also gets into the water for the swim. The lucky catcher of the barrel with red wine gets a reward, like for example a golden coin showing the face of John the Baptist. 
the participants or organizers and the public present at the festivities or events possess the significance of the holiday as well as the chosen elements used in representations of tradition, then we can talk of them as being their "symbolic capital". As a matter of fact, pertaining that symbolic capital makes the "long lasting" structures persist because the actors are the ones to act, choose strategies in the frames of the prescribed models of behaviours determined by the community. However, besides revitalization of spiritual / ritual kinship through celebrations that show the past as a meaningful symbol of a modern national identity, on the other hand, the spiritual kinship shown through cultural events can also be seen as a tourist offer. In this case we can say that commercialization of identity cultural goods events contribute to the development of cultural, religious and rural tourism.

\section{References}

Albvaš, Moris. 1999. „Kolektivno i istorijsko pamćenje, Autobiografsko i istorijsko pamćenje: njihova prividna suprotnost." R.E.Č. Časopis za književnost i kulturu, i društvena pitanja 56(2): 63-82. http://www.b92net/ casopis_rec/56.2/pdf/04.pdf (accesed on 15.4.2014).

Bandić, Dušan. 1980. Tabu u tradicionalnoj kulturi Srba. Beograd: Biblioteka XX vek.

Bauzinger, Herman. 2002. Etnologija. Od proučavanja starine do kulturologije. Beograd: Biblioteka XX vek.

Bendix, Regina. 2007. "Kulturelles Erbe zwischen Wirtschaft und Politik. Ein Ausblick." In Prädikat "HERITAGE". Wertschöpfungen aus kulturellen Ressourcen, eds. Dorothee Hemme, Markus Tauschek und Regina Bendix, 337-356. Berlin: LIT Verlag.

Bendix, Regina. 2013. „Nasljedstva: posjed, vlasništvo i odgovornost." U Proizvodnja baštine. Kritičke studije o nematerijalnoj kulturi, ur. Marijana Hameršak, Iva Pleše i AnaMarija Vukušić, 353-376. Zagreb: Institut za etnologiju i folkloristiku. 
Bošković-Stulli, Maja. 1971. „O folklorizmu.” U Zbornik za narodni život i običaje južnih Slovena, ur. Ljubo Babić i Ferdo Čulinović, 165-186. Zagreb: JAZU.

Burdije, Pjer. 1999. Nacrt za jednu teoriju prakse. Tri studije o kabilskoj etnologiji. Beograd: Zavod za udžbenike i nastavna sredstva.

Čapo Žmegac, Jasna. 2001. „Od lokalne do nacionalne zajednice: seljačka društvena struktura." U Hrvatska tradicijska kultura: na razmeđu svjetova i epoha, ur. Zorica Vitez i Aleksandra Muraj, 497-542. Zagreb: Barbat, Galerija Klovićevi dvori, Institut za etnologiju i folkloristiku.

Carsten, Janet. 1995. "The substance of kinship and the heat of the hearth: feeding, personhood, and relatedness among Malays in Pulau Langkaw."American Ethnologist 22(2): 223-241.

Carsten, Janet. 2004. After Kinship. Cambridge: University of Edinburg, Cambridge University Press.

Connerton, Paul. 1989. How Societies remember.Cambridge-New York: Cambridge University Press.

Connerton, Paul. 2004. Kako se društva sjećaju. Zagreb: Antibarbarus.

Carsten, Janet,ed. 2000. Cultures of Relatedness: New Approaches to the Study of Kinship. 2000. Cambridge: University of Edinburg, Cambridge University Press.

Hammel, A. Eugene. 1968. Alternative Social Structures and Ritual Relations in the Balkans. New Jersey: Prentice-Hall, Inc., Englewood Cliffs.

Ibsen, Charles A., Klobus, Patricia. 1972. "Ficitve kin term use and social relationships: Alternative interpretations." Journal of marriage and the family 34(4): 615-620.

Ivanović, Zorica. 2008. „O izučavanju srodstva u poslednjim decenijama XX veka." Etnoantropološki problemi 3(2): 107138. 
Ivanović, Zorica. 2008a. „Pogled na savremene transformacije antropološke teorije i prakse." Antropologija 6: 88-116.

Jelinčič, Daniela Angelina i Žuvela A. Bušnja. 2008. „Uloga medija u predstavljanju, mijenjanju i kreiranju tradicije." U Predstavljanje tradicijske kulture na sceni i и medijama, ur. Zorica Vitez i Aleksandra Muraj, 51-63. Zagreb: Hrvatsko etnološko društvo.

Kazer, Karl 2002: Porodica i srodstvo na Balkanu: Analiza jedne kulture koja nestaje. Beograd: Udruženje za društvenu istoriju.

Kelemen, Petra i Škrbić Alempijević, Nevena. 2012. Grad kakav bi trebao biti. Etnološki i kulturnoantropološki osvrti na festivale. Zagreb: Naklada Jesenski i Turk, 2012.

Kovačević, Ivan. 2007. „Gastronomske tradicijade.” u Kovačević, Ivan (ur.) Antropologija tranzicije, 109-153. Beograd: Srpski genealoški centar - Odeljenje za etnolgiju i antropologiju Filozofskog fakulteta Univerziteta u Beogradu. http://www.anthroserbia.org/

Lozica, Ivan. 2008. „Inscenacija običaja kao kazališna predstava.” U Predstavljanje tradicijske kulture na sceni i u medijama, ur. Aleksandra Muraj i Zorica Vitezur, 241-249. Zagreb: Hrvatsko etnološko društvo.

Nikočević, Lidija. 2013. „Kultura ili baština? Problem nematerijalnosti." U Proizvodnja baštine, Kritičke studije o nematerijalnoj kulturi, ur. Hameršak, Marijana, Iva Pleše i Ana-Marija Vukušić, 336-350. Zagreb: Institut za etnologiju i folkloristiku.

Nora, Pierre. 1989. Between Memory and History: Les Lieux de Méoire. http://www.timeandspace./viv.ua/files/session/Mo ra_105pdf

Pajević, Milica. 1999. „Pogovor.” u Nacrt za jednu teoriju prakse. Tri studije o kabilskoj etnologiji, ur. Pjer Burdije, 245-254. Beograd: Zavod za udžbenike i nastavna sredstva.

Segalan, Martin. 2009. Sociologija porodice. Beograd: Clio. 
Segalen, Martine. 1997. „Srodstveni odnosi u zapadnim (zapadnoeuropskim) društvima. Povijesne i suvremene perspektive." Etnološka tribina 20, 29-47.

Segalen, Martine. 1998. "Family and kinship in Europe." In MESS II, 21-32. Ljubljana: Inštitut za multikulturne raziskave.

Zlatanović, Sanja. 2014. „Kakav je odnos etničke i verske identifikacije u posleratnom kontekstu? Terenska istraživanja srpske zajednice na jugoistoku Kosova." U „Etnos“, religija $i$ identitet: naučni skup u čast Dušana Bandića, ur. Lidija B. Radulović i Ildiko Erdei. Beograd: Odeljenje za etnologiju i antropologiju, Filozofski fakultet Univerziteta u Beogradu.

Атанасовска, Фима, Владимир Боцев. 1992. „Некои магиски елементи во изведувањето на обичајот Водици во село Битуше." Етнолог: 98-107.

Величковска, Родна. 2008. Музичките дијалекти во македонското традиционално народно пеење. Обредно пеење. Скопје: Институт за фолклор „Марко Цепенков“.

Генчев, Стоян. 1974: „Кумството у Бъгарите.” Известия на етнографския институт и музей XVI: 83-109.

Гребенарова, Славка. 2000. „Българинът в криза - езичник, християнин или неверник." во: Жизненият цикъл. Доклади от българо-сръбска научна конфереция 12-16 юни 2000. София: Етнографски институт с музей, 89-100.

Гуди, Джак. 2005. Европейското семейство. София: Лик.

Джордано, Кристиян. 2006. Власт, недоверие и наследство. Скептична антропология. София: Полис.

Домазетовски, Петко. 1975. „Водичарските обичаи и песни во Дримкол (Струшко)." Македонски фолклор VIII(15-16): 253-262.

Закон за празници на PM, Сл. весник на PM, бр. 18/07. (Law on Holidays in Republic of Macedonia, Official Gazette of RM, no. 18/07.) 
Златановић, Сања. 2000. „Реафирмација традиције и свадбени ритуал." во: Жизненият цикъл. Доклади от българосръбска научна конферещия 12-16 юни 2000. София: Етнографски институт с музей, 223-230.

Китевски, Марко. 1982. Водичарски обичаи, верувања и песни од Дебарца (Охридско). Скопје: Институт за фолклор „Марко Цепенков".

Китевски, Марко. 1982а. „Водичарски обичаи, верувања и песни од Дебарца (Охридско).“" Македонски фолклор XV (29-30): 191-225.

Малинов, Зоранчо. 2006. Традицискиот народен календар на шопско-брегалничката етнографска целина. Посебни изданија, кн. 68, Скопје: Институт за фолклор „Марко Цепенков“.

Митерауер, Михаел. 2005. Европското семејство. Историскоантрополошки огледи. Скопје: Слово.

Неделковски, Боре. 2017. „Селските слави во горни села Скопско." Етнолог 17: 91-112.

Паликрушева, Галаба. 1975. „Кумството и побратимството на Свети Јован." Македонски фолклор VIII (15-16): 63-68.

Пейчева, Лозанка. 2008. Между селото и вселената: старата фолклорна музика от България в новите времена. София: Академично издателство „Проф. Марин Дринов”.

Пенушлиски, Кирил. 1988. „Обредните и митолошките песни.” во: Одбрани фолклористички трудови 2. Скопје: Македонска книга, 7-32.

Петреска, Весна 2002. Свадбата како обред на премин кај Македонците од брсјачката етнографска целина. Посебни изданија, кн. 43. Скопје: Институт за фолклор „Марко Цепенков”.

Петреска, Весна. 2005. Систем на сродство кај Македонците. Посебни изданија, кн. 59, Скопје: Институт за фолклор „Марко Цепенков”. 
Петреска, Весна. 2014. Културно сеќавање и презентација на минатото преку религиско-обредната пракса. Македонски фолклор XXXVI (69): 105-116.

Петреска, Весна. 2017. „Претставување на традицијата преку свадбените културни манифестации." во Традиција и современост во Македонија и Србија. Зборник на трудови, 71-89.. Скопје: Институт за фолклор „Марко Цепенков” Скопје.

Петровска-Кузманова, Катерина. 2017. „Традиција во современ контекст: фолклорни манифестации и фестивали“ во Проекции на културните традищии: БългарияМакедония,180-194БАН, Институт за етнология и фолклористика с етнографски музей. София: Издателство на БАН „Проф. Марин Дринов.

Поповски, Аритон. 1975. „Водичарските обичаи и песни во с. Битуше (Река)." Македонски фолклор VIII (15-16): 243252.

Ракић, Д. Радимир. 1972. „Кумство у православних Југословена као социјално-структурни облик." Etnološki pregled 10: 105-117.

Ренкас, Јоана. 2013. „Збор-гест-текст. Прилог во проучувањето на обредно-обичајниот комплекс на празникот Богојавление во селото Битуше." Спектар XXXI (61): 174195.

Ристовски, Блаже. 1970. Водичарски обичи и песни во збирките на Милан Ристески, Македонски фолклор III (5-6): 131154.

Целакоски, Наум. 1984. Дебарца. Обреди, магии и обредни песни. Скопје.

Шапкарев, Кузман. 1976. Избрани дела IV. Обичаи, обреди, носии, Скопје. 



\section{From the Classical Serbian Epics to The Hague Thematic Circle and Back: Decasyllabic Singing AS A LinguisTiC REgisTER SEEN FROM THE FunCTIONAl PERSPECTIVE*}

Contemporary singing to the gusle and the new decasyllabic songs made in the style of the Serbian "classical epics" - which both gained in public visibility with the break-up of Yugoslavia - is a phenomenon which calls for scholars' attention. Until recently, the interest has been reduced to the attempts of explaining its sudden expansion by relating it to the rising nationalism and populism during the 1990s. This made some authors reduce the whole contemporary singing to the gusle to the instrument for promoting the warmongering and extreme-nationalist ideas. The disdain for these ideological and political standpoints was transferred not only to the "new" singing to the gusle, but to the gusle itself and their language - which put some scholars in the situation to defend this instrument and the language of the epic genre from accusations of their "historical guilt" for the war during the nineties. This paper aims to show that the contemporary singing to the gusle - at least among the Serbian population - is a complex phenomenon (both from the thematic and functional points of view) and that the songs about the events and historical protagonists of the nineties are only one of its subtypes. Communication in epic decasyllables is discussed as one of the historically recorded registers

* This paper is a result of work within the project Interdisciplinary research of Serbian cultural and linguistic heritage. Creation of multimedia Internet portal "The Lexicon of Serbian Culture", under the $n^{\circ} 47016$, which is carried out by the Institute of Ethnology SASA and entirely funded by the Ministry of Education, Science and Technological Development of the Republic of Serbia. Here, I also express my gratitude to Smiljana Đorđević Belić who helped me with her comments and suggestions to improve the final version of the paper. 
of the Serbian language, which, as such, should not be the object of ethical evaluation since it does not imply any ethical value in its very form and structure.

Key words: contemporary Serbian epics, decasyllabic register

The contemporary singing to the gusle and the new decasyllabic songs made in the style of the Serbian "classical epics" could be defined, conditionally, as a post-folkloric variant of the genre of chronicle epics, recently named as post-folkloric epic chronicle (Ђорђевић Белић 2016). ${ }^{1}$ However, it can also embrace non-epic texts composed in epic-like style, ${ }^{2}$ mostly in epic decasyllables - although, in the majority of cases, the classical epic decasyllable (asymmetric and without rhyme) is replaced with the rhymed one.

From the time of Vuk Stefanović Karadžić (1787-1864), the most prominent collector of Serbian folk literature and a language reformer, and his own doubts about the value of the epic chronicles, this epic was mainly perceived as a kind of second-rate versified chronicles," although it was recognized as a kind of "living laboratory" for the research of epic poetry during the first half of the

1 By using the term "post-folkloric" Smiljana Đorđević Belić follows the line of S. Neklyudov (Неклюдов 1995), but she gives a typological meaning to the term of "post-folkloric". She uses the term chronicle as a qualification of the genre (epics), which refers both to the structure (composition, narrative models, realistic perspective and lower level of sublimation and symbolization) and to the temporal aspect - thematization of recent events, perceived by the singer/author and the public as a part of the present or of the recent past of the community, a specific group of people, a family, or a person (Ђорђевић Белић 2016, 21-22).

2 For more information about some of the modalities of inter-genre relations, seе Ђорђевић Белић 2016, 125-163.

3 For the resume of the approaches to the chronicle epics and the attitudes towards it in Serbia and the region of ex-Yugoslavia, see Ђорђевић Белић 2016, 68-74. 
20th century. ${ }^{4}$ After WW2, it was discussed mainly form the literary perspective and, thus, generally regarded as paraliterature with "traces of decadence and degeneration" (Детелић 1996, 22), which is aesthetically poor (Деретић 1996, 188) a sort of "song-like chronicle reports" (Килибарда 1976, 9), or, even, “decasyllabic grotesque" (Bugarski 1997). As Mirjana Detelić has shown, it is not easy to make the leap from a versified text into Poetry. In order to achieve it, a strong resonance with deep layers of epic traditional poetry has to be reached (cf. Детелић 1996) - and precisely this has been an insurmountable obstacle for the vast majority of the texts belonging to the post-folklore chronicle epics. As a product of

4 This scientifically promising approach was dominant between the two world wars. It was marked by the work of Matija Murko, Gerhard Gesemann and Alois Schmaus. These scholars saw the gusle singing of their time as highly valuable material for understanding the genre in its interaction with the life of the community and various aspects of its culture (for more detailed resume of this period of epics' studies, with references to authors and their particular works, see Ђорђевић Белић 2016, 63-65). The ideological turn imposed by the new governing elites of the communist Yugoslavia interrupted this fruitful period. Although in discontinuity with the results of the previously mentioned scholars, this approach found in North America a ground for further prolonging its existence (although indirectly, through Homeric studies). This happened by a set of circumstances: the launching of Milman Parry's Oral Formulaic Hypothesis in the 30's, the consequent overlapping of Homeric studies with those of the mechanisms of composing texts sang to the gusle and, finally, the openness of the Tito's Yugoslavia to the Western culture, which made possible Albert Lord's fieldwork in the country twice during the 50's (1950-1951 and 1958-1959) and the John Miles Foley's in 1975. The Parry and Lord's hypothesis was differently received by the Yugoslav folklorist (for more detail about the scholars involved, their works and a resume of the polemics between them, see Сувајџић 2005, 11-13). Its influence was not of a major importance in the Yugoslav formulae studies, which preferred the research line traced by Schmaus (for the resume of the argumentations and related bibliography, seе Сувајџић 2005, 13-15). Although aware of all the weaknesses in the work of her precursors (Detelić 2010), Mirjana Detelić largely built upon the concept of formula, reaching her own formula hypothesis. Focused on the poetics of the formula, she drew attention to its deeper semantic layers, which she demonstrated through the examples from the "classical" Serbin epics. Her ideas on formula were most extensively elaborated in Детелић 1996; although the topic was present in her work untill the very end of her life (Detelić, Delić 2015). 
dominantly written culture (opposed to oral culture), in which the text is fixed from the very beginning by a particular author, these songs are deprived to a great extent of the most powerful honing device to improve the song - the multiple repetition of the noncanonized text and its transmission achieved exclusively by word of mouth. ${ }^{5}$

Although it was a living cultural practice, the research interest for the chronicle epics "continued to exist on the margins of the dominant line in the circle of Serbian folklorists" (Ђорђевић Белић 2016, 66) - a tendency which could even be understood as a kind of "research censorship" used in order to avoid damaging the image of what has been perceived as an "ideal tradition" (Ђорђевић Белић 2016, 193). ${ }^{6}$

With the war which marked the disintegration of Yugoslavia, the singing to the gusle boomed as a part of a much broader phenomenon of war folklore, in which the events and the dominant personalities of that time were thematized. This branch of the chronicle epics was discussed in terms of the (ab)use of gusle singing for political purposes and, during the nineties, as a tool for the promotion of the warmongering and extreme-nationalist ideas (cf. Žanić 1998; Čolović 1993; 1997; 2000; 2008; Naumović 2009; Милојевић 2007). The disdain for the aforementioned ideologicalpolitical standpoints even shifted from the war-folklore chronicle epics to the gusle as such, which were suddenly perceived as one of the key symbols of "political mythology" responsible for the war during the nineties and also as an obstacle for joining the EU. Referring to the words of Andrej Nikolaidis "gusle kills, just like tobacco" (Nikolaidis 2004) stated in a non-scholarly text, Ivan

5 Here I refer to the majority of the contemporary songs, although, in some cases, there can be found examples of further folklorization of the text. In this respect, a good description of the contemporary practices and tendencies regarding the authorship, improvisation, canonization of the text, its folklorization etc. is recently given by Đorđević Belić (Ђорђевић Белић 2016, 49-55).

${ }^{6}$ For a more detailed insight into the approaches to the post-folkloric epic chronicle and the attitudes towards it in the second half of the XX century in Serbia and region of ex-Yugoslavia, see Ђорђевић Белић 2016, 68-74. 
Čolović launched an expanded sequence of culprits (in his case, in a scholarly intended paper): "it is not only gusle that kills, the language kills, the poetry kills, the history kills, the mythology kills, the religion kills, the so-called national-patriotic culture as a whole kills"7 (Čolović 2008, 181). Then, he clarified his words by adding that he did not consider killing to be the "fatal, substantial characteristic" of the gusle, but the result of the "long-term pedagogical work in which gusle has been reduced to become a part of the war-propagandistic arsenal during the last two centuries" (Čolović 2008, 181-182). This kind of negative attitude towards gusle soon managed to get not only into the scholarly discourse but, as it has been recently discussed (Трубарац Матић 2018, 19-55), to extend to the wider population and take roots in popular culture, TV shows, theatre, everyday language etc. The "attack" on gusle led some scholars and prominent intellectuals to "defend" the instrument and this traditional form of expression. ${ }^{8}$ However, the absurdity of the situation made the others guard distance and stick to the studying of the phenomenon of the contemporary singing to the gusle on the basis of the tradition and practice of their primary research disciplines (Големовић 2008; Кнежевић 2012; 2013; Јокић 2013; Лајић Михајловић 2014; 2016; Ђорђевић Белић 2012a; 2012b; 2013; 2015; 2016; 2017). As the aforementioned polemics is exclusively provoked by the textual rather than by the musical aspect of the songs, I will focus here on the topic from the linguistic, functional and pragmatic perspective. This means that some important issues regarding the contemporary singing to the gusle, such as the consequences of the switching from the classical decasyllable to the rhymed one will stay out of the present discussion.

Now, if we transfer the content of the polemics into the framework of the rational discourse of scholarly approach to the

7 This and all the following translations are done by Đ.T.M.

8 For example, Matija Bećković, Ljubomir Zuković, Radovan Papović, Andrej Fajgelj etc. Some of their articles on gusle and their importance and value for Serbian culture can be found on the web page of the Association of Guslars of Serbia: http://www.savezguslarasrbije.rs/o-guslama/naucni-radovi 
phenomenon, it should be discussed in relation to what is perceived as one of the most intriguing issues of the epics as such, which is "the question of the identity of the genre in the circumstances of changed functionality, i.e. the question of the relation between the function and the aesthetics of the genre in diachrony" (Лајић Михајловић 2014, 38). Thus, in order to approach the phenomenon of the contemporary singing to the gusle properly, we must focus on the problem of the identity of the genre observed in the diachronic context and, in order to determine the nature and the scope of its possible "changed functionality", we must compare it to the "classical" epics. In our case, the classical epics will be the epics of Vuk's era, since it is the oldest practice of the singing to the gusle which is extensively described.

As far as the function of the epics concerns, I give credit to the conclusions of Danka Lajić Mihajlović, who observes that the basic function of the epics is communication, which can be defined as interpersonal (which implies social interaction with present people), pseudo-communication (with God, gods, ancestors) and intrapersonal communication (with oneself) (Лајић Михајловић 2014,39 ). Besides, as a form of collective remembrance, it involves the transmission of new information, as well as of knowledge and experience regarding regulation of social relations, ethics, history and religion.

Now let's turn to the identification of the genre, which, in order to be approached comprehensively, should be observed from several analytic levels, as noticed by Detelić (Детелић 1996, 7):

"At the level of the history of verse, it is sung in the meter which comes from the pre-Slavic antiquity in an almost unchanged form (Jakobson, Ivanov \& Toporov, Gasparov) ${ }^{9}$ and, by its very structure, it normally

${ }^{9}$ Here, Detelić refers to the results of the studies of Roman Jakobson, Vyacheslav Ivanov, Vladimir Toporov and Mikhail Leonovich Gasparov regarding the Slavic epic metrics. Building upon the previous studies of comparative Slavic (Sreznevskij), Classical Greek (Bergk) and Indo-European (Meillet) metrics, Jakobson convincingly demonstrated that the Slavic epic decasyllable can be traced back to Primitive Slavic and, furthermore, that it 
"remembers" more than the words put in it. At the level of history of genres, it belongs to the developed epics of the early feudalism, founded on national consciousness and pathos (Meletinsky), which logically implies its pronounced ideological determination (protection and defence of the state, Church and nation). At the level of literary theory, it belongs to the aesthetics of identity (Lotman), which means that it cannot be understood well, nor interpreted properly, without knowing the type of culture in which such aesthetics makes sense as a value system. Finally, at the level of poetics, one cannot get anywhere without bearing in mind all the previously mentioned, i.e. no particular issue in this field can be solved if the solution does not endure the test at all the other analytical levels at the same time."

In this paper, I will discuss the contemporary singing to the gusle from the first three analytical levels mentioned above: 1) the decasyllabic epic verse; 2) the emphasized ideological content; and 3 ) the aesthetics of identity. ${ }^{10}$ The issues of poetics, literary value and the relation between the function and the aesthetics of the genre will stay out of focus. The decasyllabic singing will be primarily observed as a folkloric phenomenon, in the sense of Richard Bauman's definition of folklore as a function of shared identity (Bauman 1971, 32), which is in direct resonance with the question of functionality. But, at the same time, it will be discussed as a post-folkloric phenomenon (Neklyudov 1995), generated within a specific type of culture based on intercontextuality - in which different cultural and communicational contexts coexist in mutual interaction - written, oral and mass media communication,

comes from the pre-Slavic Indo-European antiquity (Jakobson 1966, 414-463; 1985, 22-29). Regarding Ivanov, Toporov and Gasparov they developed further research of Slavic metrics within the Tartu-Moscow Semiotic School.

10 The aesthetics of identity consists of the identity relation between the codes of the sender and the receiver, i.e. it is based on the identification of the phenomena depicted with model-clichés that the audience know in advance and expect to find in the text since they are elements of the preexistent system of cultural codes (cf. Lotman, 1970, 245-246). 
the communication through new technological channels, the commercialization of tradition, folklore and culture in general, cultural paradigms of rural and urban etc.). ${ }^{11}$

1. DeCASYllabiC METER AS A LingUISTIC REGISTER. Speaking about the differences between the song as a story about some particular event (which inspires the creation of a song) and the song as a particular performance or text, Albert Lord, in The Singer of Tales, touches on the topic of the way in which a guslar can make up a song and improve it with repeated performances. In the footnote $\mathrm{n}^{\circ} 3$ (Lord 2000 [1960], 99), he mentions how once, during Milman Parry's fieldwork in 1934, Nikola Vujnović (the person who accompanied Parry during his expedition), asked the guslar Salih Ugljanin if he could, at that very moment, make up a song about Parry's and Vujnovićs arrival and finding him to sing songs for them. Ugljanin responded that he could. He did it straight away and they recorded his performance. In the same footnote, Lord also mentions a song dedicated to Parry and his expedition (Appendix VI, 271-275), which was made up in 1933, by Milovan Vojičić, a guslar from Nevesinje. These annotations provided by Lord are relevant in terms of revealing that the guslars were actually able of speaking about the events in epic decasyllables, which means that they had the linguistic competence of using them as a linguistic register. But, is there any other recorded proof for this statement?

Actually, there is a lot. From the first extended descriptions of guslars' practice written by Vuk in the first half of the XIX century to those recorded by other collectors in the decades to follow. In his foreword for the first volume of his Serbian Popular Songs written in 1823, Vuk mentions a peasant from Tršić (Vuk's native village) who was a skilful singer and made up many humorous songs of a local, anecdotal character (of which he cites some verses), which he would compose directly after a particular event would occur (Вук

11 Recently, the contemporary practice of singing to the gusle was extensively discussed and analyzed as a post-folkloric phenomenon by Smiljana Đorđević Belić (Ђорђевић Белић 2016; 2017). 
1953 [1841] I: XIX-XXIII). Vuk's grandfather and uncle also had similar abilities. As a child, Vuk was present when his uncle, while working in the field in 1803, made up a song about the death of Smail-beg Begzadić, which occurred some 3-4 days before (Вук 1958 [1841], IV: XXIV). We know that several decades after, in the second half of the XIX century, there was a Member of Serbian Parliament who, after the assembly, was able to recite in decasyllables the debate on the bill for introducing the new monetary system into Serbia (Subotić 1932, 136). Cases of such skilled versifiers in epic decasyllables were recorded during the XX century too: in the time of the monarchy, between WW1 and WW2, Pavlović mentions a certain Milutin Pantelić, who made up a song about manipulations in the elections (the watchers of the ballot boxes and organized voting of army unites) (Павловић 1921, 157). He also made up others with different goals, like the one aimed to expose publicly the names and shameful actions of a group of sheep thieves (Павловић 1921: 157-163). Pavlović mentions an old man, Petronije Prodanović from Blaznava, who was able to make a song about every single event (Павловић 1921, 155). Some time after his daughter died, while working in the garden, he saw a rose she had planted and, while watching it, he made up a threnody in epic decasyllables in which he mourned her death (Павловић 1921, 156-157). Pavlović also writes about some soldiers who made songs on the battlefield, thematizing the injustices of municipality authorities of which they had learnt from the letters they received from home (Павловић 1921, 235-237). Finally, I will mention the song The Death of the Budimljani in Divci by Prijepolje. In 2008, almost immediately after the corpse was found of a member of the chetnik movement (who was killed and secretly buried in 1944), this song "started circulating" (mainly via e-mail) among the family members. The remains were soon exhumed and re-buried, and the song was performed on the occasion of the re-burial (Ђорђевић Белић 2016, 177-178).

The songs similar to those described, which are of private, local or short-term interest, have been often considered by guslars as inappropriate to be sung to the gusle (Ђорђевић Белић 2016, 184). As Vuk states, the same perception existed in his times as well (Вук 1953 [1841] I: XXIII). This is why they were normally quickly 
forgotten and did not remain in the chain of transmission for a long time.

Vuk describes the acquiring of the ability to make new songs as a process which takes time. According to his testimony from 1823 , "the heroic songs are mostly made up by middle-aged and elder men" and, although - in the regions where epic singing is most lively - "there is no man who does not know several songs, and there are those who know even more than fifty, and maybe hundreds of them", only those who knew at least fifty different songs, if they were talented, could make up a new one (Вук 1953 [1841] I: XVIII). He adds that nobody among the folk took for something special or worth of admiring, when someone would make a new song (Вук 1953 [1841] I: XXVI).

As we can see from Vuk's words, not all those who knew and sang songs were able to make up a new one (talent and skill were necessary). However, those who had that ability - and there was not a small number of them (since the making up of a song was not considered to be something special) - could, after having learned enough songs, master the technique to such a degree that they could easily compose new ones. As Vuk states, "just as one man speaks more beautifully and clearly than another man, the same way one sings and tells the songs" (Вук 1953 [1841] I: XXVII).

From all of the above, we see that speaking in epic decasyllables is a historically recorded register of the Serbian language - although still completely unperceived and non-described comprehensively from all the linguistic analytic levels. ${ }^{12}$ Without any pre-existing text on the subject, the mentioned singers could compose decasyllabic songs which could have literary value - e.g. those made up by Filip Višnjić (Вук 1958 [1841] IV: XII) - but could also be literary insignificant (if valued form the etic perspective), or of a short-term importance for the local community - often anecdotal and humorous, in which the register of epic decasyllables

12 Apart from this, deeper insights are needed in order to elucidate completely the coalescence of the ability of talking in decasyllables with singing them. Danka Lajić Mihajlović has recently given a revealing contribution in this direction (Лајић Михајловић 2014). 
was a parodic framework for narration. This practice of speaking in epic decasyllables could not appear out of nowhere - previous to Vuk's times, there must has existed a long lasting tradition of using epic decasyllables in this way, through which the register was shaped. The fact that the mere speaking and telling stories in decasyllables which did not resonate with "big national topics" has never been perceived as worth of transmitting to the next generations, nor being written down, can explain why there are no older testimonies of this kind of decasyllabic texts.

A good example of a wider contemporary use of epic decasyllables as a linguistic register in everyday commenting on recent events is the Twitter account Филип Вишњић, where the anonymous owner of the account leaves his short comments in epiclike style, i.e. in epic decasyllables (non-rhymed) and his followers comment on them by using also epic decasyllables (both rhymed and non-rhymed). ${ }^{13}$

Regarding the Čolović's moral accusations of gusle, the language and the poetry, one should bear in mind that the epic decasyllable is a linguistic register, i. e. an optional variety of language, which does not imply any ethical value in its very form and structure, although it can be used to convey all sort of contents (messages), which definitely can be submitted to moral judgment. The ethical value of the transmitted message lies not in the epic decasyllabic verse itself, but in the ideological contents which can be put in it.

The moral accusations on behalf of the language (as such) might even be discussed in the terms of intention to launch a new language ideology ${ }^{14}$ with the aim to make it take root in the minds

13 For the reference, see the list of Internet sources under: Twitter. Филип Вишњић.

14 I use this term in the way it is usually used in linguistic anthropology, i.e. as a set of ideas, beliefs and feelings that people have about language, which are shaped in a specific cultural context and can be linked to social, political, ideological or economic interests. They are fallacious constructs about the language which represent the interests of a particular group in society, in the way that they become instruments of power (cf. Piller 2015). 
of people. However, as any language ideology, they are only mental constructs, which do not reveal anything substantial about the language/register itself. Although, in this particular case, they reveal something else - as there are several accused parties here (gusle, language, poetry, history, mythology, religion and "nationalpatriotic culture"), which are or can be the constructive elements of personal and national identity - the abovementioned accusation can actually be qualified as an act of epistemic violence ${ }^{15}$ from the position of an "intellectual elite member", directed toward those who are to interiorize the feeling of cultural self-inferiority in order to renounce the constituent elements of their identity (cf. Fanon 2008 [1952]) ${ }^{16}$ - which opens the question of infringement of professional ethics of a researcher in the field of humanities.

2. IDEOLOGICAL DETERMINATION AND THE AESTHETICS OF IDENTITY. As mentioned before, one of the characteristics of the genre of medieval European epics - and the Serbian classical epics that stem from this epic tradition - is the ideological determination which involves protection and defence of the state, Church and

15 By epistemic or epistemological violence I refer to the act of aggression in which "the subject of violence is the researcher, the object is the Other, and the action is the interpretation of data that is presented as knowledge. (...) Epistemological violence refers to the interpretation of socialscientific data on the Other and is produced when empirical data are interpreted as showing the inferiority of or problematizes the Other, even when data allow for equally viable alternative interpretations. Interpretations of inferiority or problematizations are understood as actions that have a negative impact on the Other. Because the interpretations of data emerge from an academic context and thus are presented as knowledge, they are defined as epistemologically violent actions." (Teo 2010, 295).

16 Speaking of the "colonized mind", Frantz Fenon defines colonized people as "every people in whose soul an inferiority complex has been created by the death and burial of its local cultural originality" (Fanon 2008 [1952], 9). He describes the way this inferiority complex is inculcated by the colonizer: "there is a constellation of postulates, a series of propositions that slowly and subtly-with the help of books, newspapers, schools and their texts, advertisements, films, radio-work their way into one's mind and shape one's view of the world of the group to which one belongs" (Fanon 2008 [1952], 118). 
community. This feature can easily be recognized in numerous songs which thematize the war of the nineties: there are whole circles on particular battles and persons who participated or died in them (for example, on the Battle of Košare, or the defence of Nevesinje), the hymns dedicated to the political and military leaders during the wartime (Slobodan Milošević, Ratko Mladić, Radovan Karadžić), as well as those about soldiers and civilians who were killed in the circumstances of war and NATO bombing, songs describing war suffering or events in The International Court in the Hague. There are many among them in which can be found explicit or implicit expression of politically and nationally biased rhetoric, intention of creating personality cults or calls for mobilization for defence. I will not get into more detailed descriptions of this corpus, since Dimitrije Golemović has already done it (Големовић 2008, 103-135). However, I want to call attention to the transition from ideologically determined "classical" epics to an ideologically multidetermined genre of the contemporary chronicle epics. Generally, almost all the uprisings and wars in which the Serbs participated are thematized in guslars' songs and, in some cases, from different ideological positions. During the SFR Yugoslavia, songs celebrating Tito, Sava Kovačević and other partisan fighters, prominent members of the post-war communist elite, like Peko Dapčević or Vladimir Rolović, the communist revolution and ideology, or the post-war reconstruction of the country were sung and promoted.17 But, there are also songs coming from the opposing ideological sides, such as those thematizing the sufferings in the political prison and labour camp of Goli Otok (in which mainly Stalinists and other post WW2 sympathizers of Soviet Union were kept),18 or those

17 E.g. Poema borbi i radu, Boro i Ramiz - vjesnici kosovkskih svitanja, Crnogorski besmrtnici, Pogibija generala Vladimira Rolovića, Pjesme iz NOB-a Milisava Puzovića, Sedam sekretara SKOJ-a, Herojima Sutjeske / Bitka za ranjenike etc. were all released by Jugoton, the largest record label and chain record store in SFRY. For more details about these and all other sources recorded on vinyl and tapes, see Sources.

18 E.g. Pismo sa Golog Otoka, Crnogorka kune od nevolje Goli Otok i Lijevče Polje (Jovanović \& Bošković); Ђавоље коло на Голом Отоку. For more details about these and all the other sources from internet, see Sources. 
coming from the monarchists' side, celebrating the chetnik movement, their prominent figures and battles against the German and ustasha armies during WW2, or those about the members of the royal dynasty of Karađorđević, etc. All of these songs, with an unequivocal ideological-political motivation, make a kaleidoscopic image of politically and ideologically turbulent times marked by conflicts on different political bases and inspired by opposing ideological standpoints. As illustrated above, all of these groups found a channel for their own identity sharing through singing to the gusle about their own convictions, their common truth and their own historical experience, no matter if their ideology was inspired by the right-winged, "national-patriotic culture" (cf. Čolović 2008, 181), or different fractions of the left-winged proletarian international movements.

The "destiny" of being easily (ab)used for political or ideological purposes can be linked to some point to the third characteristic of the genre (mentioned above), which is the aesthetics of identity, since it implies the identity relationship between the epic song, the cultural reality and the communicational system of cultural codes used by the sender and known to the receiver of the message. Regarding the politically or ideologically engaged songs about the conflicts in the nineties (created in the circumstances of war), Đorđević Belić noticed the importance of intercontextual influences between the agressive language of the media in the wartime and the process of conceptualizing the epic opponent/the enemy in these epic chronicles (Ђорђевић Белић 2016, 124).

Besides, the gnoseological nature of the aesthetics of identity, which is based on establishing an identity relation between the everyday life phenomena and particular logical and cultural models, can be used with ideological and political intentions, or they can simply serve as a tool for expressing political standpoints and commenting on events from everyday political and public life - as it is the case in the songs about the political and social issues, problems and polemics of contemporary Serbia and the rest of the world (songs on the referendum for the independence of 
Montenegro, economical migration, the International Court in The Hague, low nativity rate, panegyric songs about Vladimir Putin, etc.).

Although (as far as I know), they have not been sung yet to the gusle, but only composed in epic decasyllables, there are also songs critical toward the current Serbian government, which can be read on the Facebook page of Anica djevojka. There the author (Ana Ilić) parodies daily-political events in Serbia and their protagonists (the municipal elections in Belgrade, the exposé of the current Prime Minister Ana Brnabić, various activities and declarations of the President Aleksandar Vučić, the Minister of Foreign Affairs Ivica Dačić and his singing skills, the new Slavija square fountain, the opening of the first IKEA store in Serbia, the problems with the garbage landfill in Vinča, etc.), doing it almost immediately after they take place. These texts drew broader attention after the author's appearance at the discussion What's there Stinking Around the Landfill in Vinča organized by the initiative $\mathrm{Ne} d a(v i) m o$ Beograd ('Don't let Belgrade d(r)own'), held on July 4th 2017 in Belgrade, in which she recited a song of hers that thematized the problems with the aforementioned landfill. The texts of Ana Ilic gained additional popularity when the same song was cited in Borka Pavićević's article Tvoje govno, tvoja odgovornost ('Your shit - your responsibility'), published in the pro-opposition newspaper Danas on July 9th 2017.

To conclude, the identification of the entire Serbian postfolkloric chronicle epics with just one political or ideological option is simply not possible. Although I give all the credit to Čolović when he observes that in the political life the gusle "symbolizes the vox populi" and that their main function in political communication is to present those whose ideology is promoted as a legitimate and authentic representative of the people (Čolović 2008, 142-143), it should be noticed that there is almost no political option or ideology among the Serbian population whose bearers have not (ab)used the epic decasyllable register for expressing their political standpoints, 
although there have always been guslars who opposed this practice. ${ }^{19}$

Finally, Čolović stated that the gusle have been reduced to become a part of the war-propagandistic arsenal during the last two centuries. But, is this actually true? Are the gusle nowadays truly reduced to that?

3. NON-ENGAGED CONTEMPORARY CHRONICLE EPICS AND OTHER GENRES SUNG TO THE GUSLE. Apart from the aforementioned engaged contemporary epic chronicles, there is a vast corpus of non-engaged songs - "classical-historical", didactic, religious, legendary, even mythical-legendary songs, but also those sung in ritual context, like toasts on the occasion of slava feasts and weddings, or, as we have seen, even re-burials. Besides, there are typically post-folkloric epic decasyllabic texts (which are not a part of guslars' repertoire), like those created and spread on internet among members of particular sub-cultural groups, e.g. the fans of the cult drama television series Game of Thrones, which can be read on the Facebook page Becmepoc је срце Србије ('Westeros is the heart of Serbia') ${ }^{20}$ - the name which directly refers to the slogan Косово је срце Србије ('Kosovo is the heart of Serbia') and, indirectly, to one of the most important thematic circles of the Serbian "classical" epics.

One of the largest groups of songs is the one dedicated to the tragically or prematurely died persons, among which there are public and semi-public figures (e.g. the songs thematizing the death of a football player Dragan Mance in a car accident, ${ }^{21}$ the death of Zvonko Osmajlić - a personal bodyguard of the politician Vuk Drašković - in the assassination on the Ibar Highway22 the

${ }_{19}$ About the debate among the guslars on this issue see Ђорђевић Белић 2016, 193-200.

20 In these versified texts, particular episodes or contents from the series are retold in epic decasyllables. See Вестерос je срие Србије; Ilić 2014; Илић 2014a; 2014б. I am grateful for this information to Ivana Živaljević.

21 Tragična smrt Dragana Mancea, see Sources.

22 Погибија Звонка Осмајлића на Ибарској магистрали, see Sources. 
assassination of Pavle Bulatović, former Minister of Interior Affairs of Montenegro, ${ }^{23}$ the murder of the judge Milorija Đukić at her workplace ${ }^{24}$ etc. However, there is also a vast corpus of songs about the death of completely anonymous young people killed in traffic ${ }^{25}$ and other accidents, ${ }^{26}$ or victims of high school bullying. ${ }^{27}$ Although many of them are ordered by the relatives of the victims (and therefore paid for), there are also songs composed spontaneously, by the relatives of the deceased, which are the expression of their personal grief (Ђорђевић Белић 2016, 186).

Although we do not have recorded evidence of this kind of family folklore older than the already mentioned (the beginning of the XX century, provided by Pavlović), the probability that they existed long before the XX century must be high and should not be rejected, since the communicational goals achieved through them enter within the scope of the oldest functions of the epics, such as the glorification of and the communication with the deceased and the ancestors. These songs provide for the listeners a point of meeting with the deceased, who is brought to their memory. Also, they represent a kind of compensation for a prematurely interrupted life, since the life of the deceased is "prolonged" in the memory of the members of the community by the means of the song 28 and, finally, they serve to introduce the deceased among the rest of the dead family members and ancestors (who are often explicitly mentioned in this kind of songs).

Another group of songs which share the same link to the cult of ancestors are the decasyllabic toasts sung by the guslars at slava

23 Погибија Павла Булатовића, see Sources.

24 Погибија судије Милорије Ђукић, , see Sources.

25 E.g. Помен рана момачког јаблана, see Sources.

${ }^{26}$ E.g. Братске ране невидане, about the death of Arsenije Janjić in a snowstorm on a mountain, see Sources.

27 Е.g. Убиство Милоша Гојковића, see Sources.

28 Đorđević Belić considers that it should not be excluded the intention that the family chronicle goes beyond the limits of family folklore, since the families often hire the most famous guslars to sing these songs (Ђорђевић Белић 2016, 190). 
feasts and at weddings. Among the Serbs of the Dinara mountain range, there still exists a custom to invite a guslar to the wedding to sing a wedding toast speech, made up for that occasion, in which the guslar addresses, by name, the groom, the bride, their parents, the best man etc. and expresses the wishes appropriate for each one of them. Although he is usually paid for this, he can also be a family member - for example, in the case of the wedding of Dragan Avdalović from Bileća, when the guslar was his uncle Momir Moša Avdalović (his father's brother). ${ }^{29}$ The uncle sings to the gusle and thanks God for the opportunity for such a joy, he recalls in the memory of the listeners the significant ancestors of the groom's family, clan and tribe; he encourages the groom, advises him, wishes him luck; he tells to the bride's family that she is entering into a good and honourable family etc. Just as in the previous case, the guslar introduces a new member (a bride) to the family and to the ancestors (who are invoked by mentioning their names in the toast) - since they supposedly attend the wedding to witness the initiation of the newlyweds to the community of reproductively active members of the family, through whom the lineage will be continued.

FINAL REMARKS. The epic decasyllabic meter is one of the historically attested registers of the Serbian language, in which it is possible to speak on any subject, with any possible communicational intention, both with and without the ambition of achieving a literary valuable text. As a linguistic register the epic decasyllabic verse does not imply any ethical value in its very form and structure, although it can be used to transmit contents (messages) which can be are submitted to moral judgments. Among the Serbian population, the contemporary singing to the gusle is a complex phenomenon, which exists between the traditional folkloric gender (deeply rooted in archaic beliefs, practices and functions of epic singing) and the post-folkloric phenomena generated within a culture of constant inter-contextual exchange of languages (verbal and non-verbal) of different channels of communication. Their bearers can belong to different

\footnotetext{
${ }^{29}$ For the recording, see Avdalović in Internet sources.
} 
social/political/ideological/cultural and sub-cultural groups, with their own sets of ideas, preferences and specific needs of common identity sharing. Shaped by tradition through the centuries as a tool for homogenizing the identity of a group through gathering its members around common truths - which is a necessary aspect of groups' survival strategies - singing to the gusle still has considerable mobilization potential and can be politically and ideologically (ab)used. However, this characteristic is just a communicational potential of the language as such and the outcome of the communicational act, the moral and other consequences and effects of the message depend exclusively on the ethical, social and historical responsibility and consciousness of the participants in the act of communication.

\section{References}

\section{Sources}

Published sources

Вук - Стефановић Караџић, Вук. 1953 [1841]. „Предговор.“ Српске народне пјесме І. Прир. Војислав Ђурић. Београд: Просвета: vii-Li.

Павловић, Јеремија. 1921. Живот и обичаји народни у Крагујевачкој Јасеници и Шумадији. СЕЗб 22. Живот и обичаји народни, књ. 12. Београд: Српска краљевска академија.

Lord, Aleber B. 2000 [1960]. The Singer of Tales. Eds. Stephen Mitchell and Gregpry Nagy. http://nrs.harvard.edu/urn3:hul.ebook:CHS_LordA.The_Singer_of_Tales.2000. (accessed on February 2nd 2018)

Subotić, Dragutin. 1932. Yugoslav Popular Ballads: Their Origin and Developement. Cambridge: Univesity Press.

Sources on tapes and vinyl

Ђавоље коло на Голом Отоку. Копривица, Ђорђије - Ђоко. Jugodisk, БДН-3777, 1990. 
Boro i Ramiz - vjesnici kosovkskih svitanja. Milutin Perović. Jugoton, LSY- 61677, 1982

Crnogorski besmrtnici. Milivoje Mujo Nikčević, Milorad Mišo Vujović, Slavko Lazarević i Vojo Radusinović. Jugoton, LSY-65009, 1975.

Poema borbi i radu. Members of the Assotiation og guslars "Vuk Karadžić“. Jugoton, LSY-61330,1981.

Pogibija generala Vladimira Rolovića. Vojo Radusinović. Diskos, NDK-5114, 1971

Tragična smrt Dragana Mancea. Vukomir i Vukosav Šćekić. Jugoton. CAY-1881, 1986.

Pjesme iz NOB-a Milisava Puzovića. Jugoton, Stereo, LSY- 61348

Sedam sekretara SKOJ-a. Zdravko Điković i Rajko Žižić. Jugoton, LSY- 61552, 1981

Herojima Sutjeske / Bitka za ranjenike. Various. Jugoton, LSY61954Битка за рањенике,

\section{Internet sources}

Вестерос је срце Србије. Facebook page: 2017. Смрт Кала Драга. https://www.facebook.com/vesteros.srbija/ (accessed on March 11 ${ }^{\text {th }}$ 2018). The text can be found at: https://www.facebook.com/notes/\%D0\%B2\%D0\%B5\%D1 \%81\%D1\%82\%D0\%B5\%D1\%80\%D0\%BE\%D1\%81\%D1\%98\%D0\%B5-\%D1\%81\%D1\%80\%D1\%86\%D0\%B5$\% \mathrm{D} 1 \% 81 \% \mathrm{D} 1 \% 80 \% \mathrm{D} 0 \% \mathrm{~B} 1 \% \mathrm{D} 0 \% \mathrm{~B} 8 \% \mathrm{D} 1 \% 98 \% \mathrm{D} 0 \% \mathrm{~B} 5 /$ $\% \mathrm{D} 1 \% 81 \% \mathrm{D} 0 \% \mathrm{BC} \% \mathrm{D} 1 \% 80 \% \mathrm{D} 1 \% 82-$ $\%$ D0\%BA\%D0\%B0\%D0\%BB\%D0\%B0\%D0\%B4\%D1\%80\%D0\%B0\%D0\%B3\%D0\%B0/49839086 $7168444 /$

Братске ране невидане. Стеван Мишо Поповић. https://www.youtube.com/watch?v=HGgiUxBaY0o (accessed: July, 12th 2017) 
Илић, Стефан. 2014. Страдање Старка Ненада. http://soleplain.blogspot.rs/2014/04/blog-post.html (access: February, 8th 2018)

Илић, Стефан. 2014а. Смрт краља Џофрија. http://soleplain.blogspot.rs/2014/04/blog-post_22.html (access: February, 8th 2018)

Илић, Стефан. 2014б. Бој на Црнобујищи. http://soleplain.blogspot.rs/2014/05/blog-post.html (access: February, 8th 2018)

Писмо са Голог Отока. Славко Јекнић. https://www.youtube.com/watch?v=v0N4c-GQq64 (access: July, 12th 2017)

Погибија Звонка Осмајлића на Ибарској магистрали. Радојица Бугарин.

https://www.youtube.com/watch?v=2kihVkdM70g (accessed: July, 12th 2017)

Погибија Павла Булатовића. Божидар Ђукић. https://www.youtube.com/watch?v=KUn0-ou88Uw (accessed: July, 12th 2017)

Погибија судије Милорије Ђукић. Милош Шегрт.

https://www.youtube.com/watch?v=jUr_4jnfHE8 (accessed: July, 12th 2017)

Помен рана момачког јаблана. Властимир Бараћ. https://www.youtube.com/watch?v=GCAu4NoS5l8 (accessed: July, 12th 2017)

Убиство Милоша Гојковића. Петар Шишовић.

https://www.youtube.com/watch?v=4n-K8vZ93UE (accessed: July, 12th 2017)

Anica djevojka. Facebook page: https://sr-rs.facebook.com/Anicadjevojka-405368236226648/ (accessed on 11 th of March 2018) 
Avdalović, Moša. Performance of a wedding toast. 2015 https://www.youtube.com/watch?v=VHRLMWhgE08 (accessed, July 15th 2017)

Association of the Guslars of Serbia:

http://www.savezguslarasrbije.rs/o-guslama/naucni-radovi

Crnogorka kune od nevolje Goli Otok i Lijevče Polje. Slavko Jovanović i Drago Bošković.

https://www.youtube.com/watch?v=zj8yERVNI68

(accessed on 1st of March 2018)

Ilić, Stefan. 2014. Žitije Džona Snježnoga.

http://srpski.anglozine.com/zitije-dzona-snjeznoga/ [access:

February, 8th 2018]

Jovanović, Slavko. Drago Bošković (guslars). Crnogorka kune od nevolje Goli Otok i Lijevče Polje

https://www.youtube.com/watch?v=zj8yERVNI68 (access:

February, 8th 2018)

Pavićević, Borka. 2017. „Tvoje govno, tvoja odgovornost“. Danas.

Belgrade, July 9th. https://naslovi.net/2017-07-

09/danas/tvoje-govno-tvoja-odgovornost/20207506

(accessed on July 10th, 2017)

Twitter. Филип Вушњић. https://twitter.com/gusleonline (accessed on Jun 10 2018.)

\section{Bibliography}

Големовић, Димитрије. 2008. Пјевање уз гусле. Београд: Српски генеалошки центар.

Гаспаров, Михаил Леонович. 1989. Очерк истории европейского стиха. Москва: Наука.

Детелић, Мирјана. 1996. Урок и невеста. Поетика епске формуле. Београд: Балканолошки институт САНУ.

Ђорђевић Белић, Смиљана. 2012а. „Методологија теренског истраживања фолклора: текстуализација усмене епике." Српско усмено стваралаштво у интеркултурном коду. Ур. 
Бошко Сувајџић. Београд: Институт за књижевност и уметност. 277-310.

(Джорджевич, Сміляна). 2012b. „Методологічні проблеми територіального дослідження фольклору: репертуар гуслярів.“. Народна трорчість та етнологія 2: 94-100.

. 2013. „Нека је женско, али биће гуслар: идеологија једног инструмента“. Музикологија 14: 159-187.

. 2015. „Епске хронике балканских и Првог светског рата (од дневничних/мемоарских белешки до конститутивних елемената институционализованих комеморативних пракси)." Научни састанак слависта у Вукове дане 44/2: 183-192.

. 2016. Постфолклорна епска хроника. Жанр на граници и граница жанра. Београд: Чигоја штампа - Институт за књижевност и уметност.

. 2017. Фигура гуслара - хероизирана биографија и невидљива традиција. Београд: Институт за књижевност и уметност.

Јокић, Јасмина. 2013. „Савремена проучавања епског (гусларског) стваралаштва." Савремена српска фолклористика. Ур. Зоја Карановић, Јасмина Јокић. Нови Сад: Универзитет у Новом Саду - Центар за истраживање српског фоклора, 251-260.

Кнежевић, Саша. 2012. „Епска пјесма о отаџбинском рату“. Наука и идентитет 6/1, 371-378.

Кнежевић, Саша 2013. „Гусларство - фолклоризам или жива традиција?." Савремена српска фолклористика. Ур. Зоја Карановић, Јасмина Јокић. Нови Сад: Универзитет у Новом Саду - Центар за истраживање српског фоклора, 261-267.

Лајић Михајловић, Данка. 2014. Српско традиционално певање уз гусле. Гусларска пракса као комуникациони процес. Београд: Музиколошки институт САНУ. 
Лајић Михајловић, Данка и Смиљана Ђорђевић Белић. 2016. „Певање уз гусле и музичка индустрија: гусларска извођења на првим грамофонским плочама.“ Музикологија 20(1): 199-222.

Милојевић, Јасмина. 2007. „Ново гусларство - оглед о традиционалном музичком облику у популарној култури. Култура 116-117, 123-140.

Неклюдов, Сергей Ю. 1995. „После фольклора“. Живая старина $1,1-5$.

Поповић, Данијела. 2014. „Ратне песмарице - певање 'на народну'." Србија у књижевности о Првом светском рату. Ниш: Центар за научноистраживачки рад САНУ Универзитет у Нишу, 29-38.

Поповић, Данијела. 2015. „Путем славе’ Јована Маговчевића на граници између усмене и писане књижевности“. Научни састанак слависта у Вукове дане 44/2, 191-202.

Сувајџић, Бошко. 2005. Јунаци и маске: тумачење српске усмене епике. Београд: Друштво за српски језик и књижевност Србије.

Трубарац Матић, Ђорђина. Гусле наше насушне. Полемика о гуслама сагледана у прагматичко-функционалном кључу. Београд: Етнографски институт САНУ, 2018.

Bauman, Richard. 1971. "Differential Identity and the Social Base of Folklore." The Journal of American Folklore. Toward New Perspectives in Folklore. 84(331): 31-41.

Bugarski, Ranko. 1997. Jezik od mira do rata. Beograd: XX vek.

Čolović, Ivan. 2000. Politika simbola - ogledi o političkoj antropologiji. Beograd: XX vek. (Drugo ilustrovano izdanje izdanje).

Čolović, Ivan. 2008. „Sve te gusle. Prilog proučavanju političke istorije jednog muzičkog instrumenta." u Balkan - teror 
kulture -Ogledi o političkoj antropologiji 2. Beograd: Biblioteka XX vek, 133-182.

Detelić, Mirjana. 2010. "Parry-Lord-Foley: And What Can We Do With Them." Serbian Studies Research 1(1). Novi Sad: Association for the Development of Serbian Studies, 5-17.

Detelić, Mirjana, Lidija Delić (eds.). 2015. Epic Formula: a Balkan Perspective. Belgrade: Institute for Balkan Studies SASA. Special editions 130.

Fanon, Frantz. 2008 [1952]. Black Skin, White Mask. London: Pluto Press.

Jakobson, Roman. 1966. Slavic Epic Studies in: Selected Writings. Ed. Stephen Rudy. Vol. 4. The Hague: Mouton.

Jakobson, Roman. 1985. Comparative Slavic Studies. The CyrilloMethodian Tradition in: Selected Writings. Ed. Stephen Rudy. Vol. VI. Berlin - New York - Amsterdam: Mouton Publishers.

Lotman, Jurij. 1970. Predavanja iz strukturalne poetike. Translated by Novica Petković. Sarajevo: Zavod za udžbenike i nastavna sredstva.

Nikolaidis, Andrej. 2004. „Gusle light. Cenzura za Mladića i Karadžića", Slobodna Bosna, Sarajevo, November $4^{\text {th }}$.

Piller, Ingrid. 2015. "Language ideologies." The International Encyclopedia of Language and Social Interaction (Karen Tracy, Cornelia. Ilie and Todd Sandel, eds.), 1-10. West Sussex: John Wiley \& Sons Inc.

Teo, Thomas, 2010. "What is Epistemological Violance in the Empirical Social Science?." Social and Personal Psychology Compass. 4(5): 295-303.

Žanić, Ivo. 1998. Prevarena povijest: guslarska estrada, kult hajduka $i$ rat u Hrvatskoj i BiH 1990-1995. Zagreb: Durieux. 

UDK: $39+348.011 .3$

DOI: $10.33876 / 978-542-110-238-0 / 115-131$

Katerina Petrovska-Kuzmanova

\section{ASPECTS OF THE RESEARCH OF THE ROLE OF RUSALIAN Processions in FolK Tradition}

Rusalian ritual processions with their characteristics attract the attention of folklore researchers in the past and today, because they are one of the most interesting syncretic forms. In the richness of forms and figures of speech, folklorists find a constant provocation for researching the rituals related to these dances. They, with their complex organization, the series of taboos which follow them, the specific clothing, the way of movement and dancing leave space for various scientific interpretations. The paper deals with a comparative analysis of the traditional and contemporary aspects of Rusalian ritual processions. Researching Rusalian processions shows that the way these rituals are performed in contemporary conditions gives them new meanings and functions. Their initial goal was to dance for health and prosperity. That's why the belief of their health mission is widespread among the people. However, it should be noted that over time the function of these processions changes. From magical it becomes more and more social, which can be observed by the auction of the collected products, joint dinner of the participants and the use of collected assets for the collective good of the community. The paper also elaborates on the contemporary aspects of Rusalian processions and their continuation today, as well as a folk tradition.

Key words: Rusalian ritual processions, magical function, social function, tradition, contemporary

Rusalian customs, as one of the most interesting syncretic forms in Macedonian folklore, have attracted the attention of folklorists in the past and today. These ritual dances are first mentioned in a written document by the Byzantine writer Demetrios Chomatenos in 1230 (Klickova 1969, 377-385). The most detailed description of these ritual processions available to 
Macedonian folkloristics comes from Kuzman Shapkarev (Shapkarev, 1894, 7-21). It contains information about the makeup of the troupe, their clothing, the props they use and a string of taboos and beliefs connected to the Rusalii. He describes these troupes as groups of 20-30 men grouped in inseparable pairs, dressed in a special way and armed with swords, and the hierarchy and discipline on the highest level. On Christmas they said goodbye to their closest ones and started towards the church where after receiving a blessing they went on a tour through the villages. During the movement of the procession, its members stuck to exactly determined rules: they didn't talk to each other, didn't cross themselves while eating, didn't bless when they drank, didn't greet, didn't step in water, walking in pairs next to each other, they didn't let anyone break the bond between them and everyone stepped in the steps of his predecessor, if anyone got left behind his partner didn't leave him but stood by him and he would sway his sword above his head to protect him from evil spirits. They were especially welcomed in the houses where someone was ill, and they had to dance in front of him and touch him with their swords. They also crossed the swords at the front doors of the houses, as well as above the people they met on their way. When they reached the village, they couldn't meet their relatives, if they encountered a well, dry wood, old graveyard, crossroad; they went around them three times and crossed their swords. In Rusalian rituals, like in all male processions, if two groups encountered, a battle happened. If two Rusalian groups met they fought to the death, unless one of them surrendered. Then they had to pass under the swords of the winning group. From Shapkarev's text we can see a series of important information related to the older state in the performance of Rusalian dances as well as their geographic distribution. Shapkarev locates these Rusalian processions in the region of Enidze-Vaedarsko, Solunsko Pole and Kilkis. ${ }^{1}$ Next to the string of

1 It should be mentioned that the population that lived in the vicinity of the town Kilkis in the beginning of the 20th century with the unrest in this area migrated to Strumica and the surroundings of Blagoevgrad, Petrich and Sandanski. The migrants to Strumica, so called Bezhanci continued to foster their culture. In the Strumica region the Rusalii are a part of that cultural 
invaluable information with which folkloristics still operates today, he also notes that these male processions undergo changes over time. In this text we will focus on these changes and consequently on the perspective of the research that changes over time along with them.

Nikita Tolstoy considers Rusalian dances as a folk drama within winter rituality along with all other male processions characteristic for Macedonia and the Balkans in the period of the so called "unchristened days" ( $7^{\text {th }}-19^{\text {th }}$ of January). He notes that Rusalian male ritual processions are concentrated in a certain geographic area, the southeastern part of Macedonia; they have characteristics that separate them from the other processions that are present in other parts of the country in the same period, and are known as masked ritual processions. The first characteristic that separates them from other male ritual processions is the way they dress, they're dressed in special Rusalian dress. ${ }^{2}$ These ritual processions exhibit a pronounced presence of Christian elements, as seen in the fact that the beginning and end of the custom is marked by going to church and receiving communion/blessing before the beginning and asking for forgiveness at the end, which also separates them from other male customary processions. Another characteristic of these processions is the blessing when collecting gifts, they said: "May St. Mary help you". Then it comes to the rules of movement of the procession in inseparable pairs, it can be said that it "can mean the duality of a person, but also an element of the cult of twins" (Tolstoy 1995, 221). This movement, along with the dances with swords they perform, the taboos and other elements point to their chthonic essence. The elements that connect the Rusalii with the cult of the dead are important for their genesis and the functional essence pointed towards the expectations of the new

treasure of the refugees from Kilkis after the Balkan wars, which they continued to practice and maintain.

2 It's a typical festive costume which separates itself by the special symbolism of the elements that complement it, like the cross, which is made by crossing two scarfs on the chest and the cross made of cables on the socks, these elements undoubtedly witness the entering of Christianity and its adaptation to the old pagan cults. 
year: securing fertility, health and happiness. After the end of the twelve-day campaign, the group first went to the local church, where they were met by their closest family and friends. Tolstoy points out the end stage of the custom as very important, when the troupe enters the church and takes off their hats, and replaces the swords with candles, after which the troupe dismisses. All these elements which make up the Rusalian processions show that this is a cult that is connected to nature, which was later expanded with belief in supernatural beings that wander in the period of "unchristened days" and the need for protection from them, as well as the fact that these pagan cults and beliefs are also connected with Christian elements. In this context Tolstoy (Tolstoy 1991, 221) notes that the chthonic demonic essence is not always directed negatively (it can bring death and destruction, but also health), as is the case with these troupes which enter the houses of the sick and cross their swords above them with the goal of their recovery. According to Tolstoy, the magic basis of these dances is contained in the moves, the play and sound, and the special clothing - with which they imitated fairies, kestrels and imaginary beings. He thinks that the props, such as the swords and the axe are "backrests" of the performance, though which the supernatural healing powers show up and give them the power to heal the ill and free then from evil and bad luck. In the Rusalian rituals, as well as other male processions, if two groups meet they fight to the death unless one of them submits. Then that group has to pass under the swords of the winning group. Tolstoy notes that this element is also a part of the chthonic demonic essence of these processions (Tolstoy 1995, 121). Taking these elements in consideration, researchers note that Rusalian processions in their most archaic layer contain the cult of the dead and initiation rituals and as such represent one of the most archaic practices in Macedonian folklore. Their connection to the cult of the dead and the belief that their actions can influence nature point to them being archaic. This can be especially seen in their belief in their power to heal the ill and protect the population from demons. The age of the procession is also shown by the props, the swords that the participants carry and the axe carried by the leader, which played an important role in magic and religion in the past. (Chajkanovic, 1973, 373-374) The pre-Christian origin of Rusalian 
processions can also be seen in the legend from Gevgjelisko which tells of their inception (Klichkova 1969, 377-385). The content of the legend corresponds to the assumptions of the connection of the Rusalian processions with the holiday "Rosaria", which is mentioned in the first century in Rome.

Out of the research done in the mid-20 ${ }^{\text {th }}$ century we will focus on the text of Vera Klickova (Klickova 1969, 377-385) which contains a through bibliography of the research on Rusalian dances in the past. It also focuses on the connection between Rusalian customs and other winter festivities in Macedonia. In the context of her research she notes the changes that these customs underwent over time, noting that they contain old pagan beliefs, on one side, and a close connection to the Christian religion on the other. After she explains these elements she focuses on the description of the troupe and its participants. In the second part of her text she describes the rituals and the actions common to Rusalii: the crossing of the swords over the ill, the fight between the troupes, the common dinner, etc. In the text she also points out their function which was first and foremost charitable and was about the progress and wellbeing of the village.

Through a chronological perspective of research that refers to Russalian customs we can draw a parallel between the writing of Shapkarev with that of the beginning of the $20^{\text {th }}$ century by Tanovic (Tanovic 1955-1957, 278-283). Stevan Tanovic, who wrote about the Rusalii states that "old people, before the freeing of these areas from the Turks (1912), pronounced the word rusalija as rusilija and that that's old games" (Tanovic 1955-1957, 278). He also points out that there's a lot of discussions about the term itself, stating theories of researchers at the time and points out that none of these theories can be connected to the Macedonian Rusalian rituals. In his research of the folklore of the Gevgelija region he also notes a string of significant information related to Rusalian dances, though which we can follow the changes that happen over time in the custom itself. He notes that the performance, clothing and props have stayed the same, but over time the size of the troupes has shrunk. In this context Tanovic (Tanovic 1957, 226) says that as time passes, the number of members in the Rusalian troupe continued to decrease, 
which was also reflected in the performance of the dances themselves. It's especially important to note that he observes the change of the function of these processions, which slowly moves from magic to social. So, it remains to be noted that the Rusalii for charitable goals (building of churches or other necessities of the village community) were played 1926 in Bogdanci and in Sekirnik in 1931.

There is no less interest in their dance, which was based on strict rules, always in the shape on an open circle in which the dancers move one after the other. One of the first researchers of the ethnocoreological characteristics of Rusalian dances are the sisters Jankovic. In the text about the Rusalii from the vicinity of Gevgelija, other than the dancing forms, they focus on other elements characteristic for these processions. They first focus on the meaning on the word rusalija and then they describe the ritual itself and the beliefs related to it. They analyzed ten ora from the repertoire: Karadzova, Umensko oro, Zlata, Gajda avasi, Karajaisuf avasi, Todoro biro kapidan, Kavadar avasi, Kapetan avasi and Razbulel se and they made a mellographic record of these. The analysis of the dances leads them to the conclusion that they can be classified in two basic groups: the easy and the difficult one. They note that the dances were accompanied by bagpipe and drums or zurna and drums. In relation to the dances they recorded, from today's aspect we can conclude that: "in the years when Jankovics researched there were a large number of ora that existed and were in the collective consciousness of the people" (Janevski 2013, 59).

Olivera Vasic, while looking for the common elements of the Rusalian ritual processions with other similar ones that occur across the Balkans, notes that even though the term rusalija is mentioned in the $12^{\text {th }}$ century, it doesn't refer to the period on which these processions take place, but is instead related to Pentecost, when there are similar female ritual processions in Serbia with a similar name called rusalje. In relation to other male ritual processions that take place in the period of the unchristened days or the "dead time", as she calls it, she notices a series of differences, mostly in their function, because the primary goal of these processions is to benefit the community and heal the sick. 
Among the differences she also notes the following elements: the connection to the church, lack of masks and the presence of a large number of ora. In relation to the dances she notes that:

"There are also dances with a large element of a battle, then with pronounced erotic action, with only a rhythmic accompaniment of the steps or with the elements and motifs of the dance that suggest growth, addressing of the ancestors to help or represent certain ritual activities and movements to initiate fertility in the following period" (Vasic 2012, 157).

The common characteristics of the Rusalii with other processions according to Vasic is the time in which they take place the so called "dead time", the ritual purity, spiritual and physical, and the use of props.

In Macedonian folkloristics, Mihajlo Dimovski researched Rusalian dances from an ethnocoreological perspective. He pays more attention to the choreographic elements in his studies, where he points out some peculiarities of the Rusalian performances in Strumica (Dimovski, 1974, 165-183) and Gevgelija (Dimovski 1975, 159-165), based on which he derives his conclusions in the given studies. He, using the descriptively-analytical mode of research, indicates the marks of the Rusalian dances though which he highlights their specificities in certain parts of Macedonia. Dimovski elaborates the ethno-choreographic elements in detail, paying special attention to the stylistic characteristics of Rusalian dances. He also researches the mero-rhythmic structure, with the goal of pointing out the fact that even though these dances look like each other, after a detailed analysis, which he does himself, we can conclude that they are rich in mero-rhythmic structures. Apart from the specifics of the musical phrases, he also focuses on the dancing phrases. He gives an especially detailed elaboration of the custom in the village of Sekirnik (Strumica), which Dimovski extends with notational examples, with which he confirms his analysis.

Ivan Ivanchan uses a comparative method to elaborate on the old ritual elements in Korchulan troupes, relating them to similar processions in the Balkans. In this context he defines dances with 
swords, classifies and groups them, indicating their connections, similarities and differences. He classifies Rusalian dances as chain dances with swords (Ivanchan 2006, 299-300). Analyzing the movements of male processions and especially the steps on which their dance is based, he concludes that these are simple movements, whose primary goal is magic, apotropaic and active. He finds the similarities of these dances in the rotations, crossing of the swords and the syncopated steps. In relation to the rhythmic particularities of the dances of the Rusalii and kulushari, he concludes that they're only similar in the simplicity of their dances. From the research of Ivanchan we find out that the similarities are found on the level of spatially-structural elements and the performance of certain figures. One of the possible interpretations of these similarities is found in the fact that their base is made of simple figures, which might have been a part of old vegetation cults, in which the swords were an apotropaic prop and a symbol of fertility.

According to Janevski (Janevski 2013, 58), in relation to the folk ora, it must be mentioned that Rusalian ora have a general character. They were performed at large gatherings, weddings and other festivities, but in more recent history when the tradition of the folk ora got lost, they stayed in a different collective consciousness as Rusalian ora. The ritual character that Rusalian dances give, are only the two ora performed at the beginning of the processions. More specifically, the movement in a specified rhythm and melody, with which they went from house to house was called Alaj, which means movement, seeking, walking. The other oro with which the magic circle around the house and commercial buildings is performed is called Trchanik or Kushija. These two ora give the procession its ritual character, while the other performed ora are general ora which were also performed on holidays, weddings and large village gatherings. The space and place for dancing was usually in the middle of the village. This wide space was usually called megdan (square). The authors who observed Rusalian groups and their ora noticed a large variety in context of the repertoire. As special characteristics he points out the forms, which in this region is an open circle, rarely also closed, and the terminology in which a 
lot of Turkish loan words can be found and ora whose content is not clear enough from the name of the oro. ${ }^{3}$ The repertoire was large and versatile, but the following ora are the most characteristic: Zlata, Gajda avasi, Karajusuf avasi, Todoro biro kapidan, Kapitan avasi, Krmazi fustan (red dress) and Ali Koch. In the past the main gatherings are dancing were the winter festivities in the period of the unchristsned days. In this period of the year in this region the male ritual processions Rusalii started off (Janevski 2013, 59).

Research undoubtedly shows that the function of Rusalian processions changes and transforms over time. New content which changes its meaning and function in folk life is added on top of the cult of the dead. At first their goal was to dance for health and fertility, though which the belief about their health mission spreads among the people. But also, it should be noted that the function of these processions changes as well, from magic it becomes more and more social, which can be seen in the auctioning of the collected products, the common dinner of the participants and the use of the collected means for the needs of the community (the village). The question of the functions seems crucial to the understanding of the folklore manifestations (but also the folklore as a whole).

"The term function, before all, means that the object which is the carrier of the function is usually used with a certain goal; their repeated use is necessary because the assumption of the function for just one use does not fit. But neither the subjective nor the unique limited habit of a certain use of the given objects doesn't make the function in the real sense of the word. It's also necessary to have a social consensus for the goal for whose achievement the object is used as a means: the specific way of using the given object must be

3 In relation to the terminology and names of the ora which have Turkish names, one of the informants from the village of Sekirnik stated that the instrumentalists have always been Turkish and the communication between them happened in Turkish, so a part of the names are also in Turkish. This statement has a logical flow and this information can be accepted as relevant (Janevski 2013, 59). 
spontaneously understandable for each member of the collective" (Mukaržovski 1987, 97).

According to this, the connection of the object with the function does not depend on the object itself but also on the human as an individual and as a part of the collective. The functions of a given human activity or work don't exist by themselves, but are deeply connected to a human interpretation. The concrete use of an object (activity, performance) can be called a goal - on the other hand, the function is not every goal, but the one that's usual (and which assumes repeated use according to the group or society). In this sense their role and function in the system of folk culture changes, it becomes societal, because the received means are used to build community objects: fountains, schools, homes, churches. This aspect of the changing of the functions of the Rusalian ritual processions is considered by Vera Gosheva in the paper The charitable component in Rusalian customs in southern Macedonia (Gosheva 2006, 203-209). The primary goal of her research is focused on the collection of gifts and their further use. First she tells us which members of the troupe collected the gifts, as well as how they were collected. After the Rusalian troupe came back from the campaign to their own village, the money was counted and the gifts were sorted and sold through an auction. At the end of the text, she focuses on the turning of the means over to the community and their use for satisfying its needs such as the building of churches, schools, fountains.

It's not a coincidence that the focus of research nowadays has moved from that of the processions from an ethnological aspect to one of the dances from an ethnocoreological aspect. The fact that since the middle of the $20^{\text {th }}$ century Rusalian processions don't walk around villages anymore, but present their cultural heritage on stage only contributes to this. In the past, Rusalian dances were passed on from the ancestors, the troupe usually started preparing three weeks before Christmas, and the younger participants learned from the older ones. Nowadays, according to my field research 
performed in the period between 2004-20104 in the area of Strumica and Demir Kapija, Rusalian processions are a part of the memories of former participants or carried on as a family tradition which continues in changed form. The focus of the preservation of this folklore is put on the performance of the dances characteristic of Rusalian groups on a stage. The cultural-artistic societies from the region of southeast Macedonia perform these dances as a part of their concerts and folk festivals. The performance always starts with the oro trchanik with which the area for the dance is determined, the dance called marshot (the march) is also performed, which has the symbolism of readiness for battle. These dances are performed as the most characteristic of Rusalian processions; other folk dances from the southeast area are performed as well. Based on the situation in the field, this procession can currently be researched in the direction of preservation of immaterial cultural heritage and from the aspect of presentation of tradition on the stage, from its adaptation for a stage performance to the actual presentation to an audience. According to the knowledge gained during the research, in both cases the carrier of these activities is the Cultural and artistic society "Rusalii" from Sekirnik, Strumica is a leader in this project.

According to this short display of the previous aspects of the research of the Rusalii it can be said that folklore as a field of culture faces changes in its subject of research, which are closely connected to the change of the function and purpose of Rusalian dances in the system of folk culture. In this context three topics are of special importance: the temporality of folklore, or the problem of the subject of research in contemporary conditions, orality and the questions related to folklore and technology, and folklore as a type of cultural production. These themes put the task of constant reinterpretation of folklore tradition in accordance with the modern before the researcher, unlike the model which treats the carriers of cultural heritage as a passive medium, that is as a passer on of

4 The field research was conducted as part of the project "Cultural heritage: research, preservation and digitalization" and for "Elaboration on the valorization of the male processions Rusalii in Macedonia" 
tradition or a living archive whose goal is to stop culture from being forgotten.

"In this model people come and go, but the culture stays, because it gets passed on from generation to generation. However, all interventions related to heritage - such as lowering the pressure of globalization - change the relation of the people towards their actions. Interventions lead to changes in the way people understand their culture and themselves. Interventions change the fundamental conditions for cultural production and reproduction. Change is an inherent part of culture, and the measures whose goal is to maintain them protect, preserve and keep separate cultural practices on the border between the attempts to freeze some practices and to take in consideration the procedural characteristics of culture" (Kirshenblatt/Gimblett 2013, 88).

In this context, the changeability and variation which appear in relation to the performance of tradition aren't a pointer to its dying, deformation or degradation, but on the contrary, the change and actualization show that it lives. This means that this folklore heritage is not determined once and for all, because it constantly changes, and through the processing of archived materials and the contemporary state of the field we can notice the changes which occurred though reconstruction of the traditional modes of performance. Taking into consideration the previous findings we can say that in general the transformation that happens in folklore performances leads to their further change, a symbolic capital through which the region or place they come from is promoted. In other words, cultural heritage as such doesn't exist - it is created, forming in this way its own type of symbolic capital. In this way cultural heritage becomes a value which refers to the past as well as the future (Bendix 2007, 8-9). The survival of Rusalian processions and their value as cultural heritage should also be observed through the prism of time. In this sense it can be said that "Time is a crucial factor for the metacultural nature of heritage" (Barbara Kirshenblatt/Gimblett 2013, 88). Based on these cultural changes, 
this form of advocacy for folklore values leads to presenting of the traditional cultural values to a much wider audience. This way the idea to present and show, in one place and available forms, multiple musically-folklore cultural specifics and differences is realized.

When it comes to the presentation of folklore tradition of a stage the inevitable question of folklorism arises. Dunja RichtmanAugustin (Rihtman-Auguštin 1978, 21-28) in her study on the relation between folklore, folklorism and modern public claims that in these cases folklore and folklorism sometimes completely switch their roles: what we keep as "original" folklore appears on the scene as a secondary, alienated existence of folklore; what we define as foklorism is realized as folklore in direct connection to certain socio-cultural groups and performers with the goal of satisfying different needs. But the presentation and promotion of traditional cultural forms and folklore in the public sphere, especially through festivals and the media, should primarily be targeted towards the benefit of the creators of the traditional cultural forms, regardless of economic interests in the promoting of cultural identity ${ }^{5}$. The main differences between folklore and folklorism are: 1 . while folklore as a part of face-to-face communication is connected to the given place and realization, the phenomenon of foklorism is determined by the technological communication and has an institutional character; 2 . while folklore has an informal, spontaneous life, folklorism stylizes folklore; 3. while the expressions of folk tradition are ongoing, foklorism strives towards archaic phenomena of folk culture; 4. while folklore lives in small groups, folklorism is a phenomenon of mass culture (Lešćak 1992, 5). Some folklorists think that folklore and folklorism differ on the level of certain concrete products: specific songs, dances, folk dress and customs. In relation to this problem of the reception of folklore itself, has changed long ago with the changing way of life in which it functioned as a part of everyday life and culture.

5This refers to the cultural identity which is built through the identification of the individual with a certain folklore performance in the local environment, which gets filled with meanings and then grows into a symbol. 
One of the tasks before the researcher in general is the constant reinterpretation of folklore tradition according to modern courses. In this sense the Rusalii can also be researched from the aspect of presentation of tradition on a stage, in all phases of the research though its adaptation to the stage, to its presentation in front of an audience. But the performance is not just a presentation, but also a place of a real gathering, which means a space in which a unique cross section between an organized presentation and everyday life occurs. What makes the performance special is that the act of performance itself and the act of its reception happen as a real activity here and now. So the performance is a part of life which performers and spectators pass together and spend in the same space where the performance and spectating occur. During the performance, a common text of the performance is created even if it doesn't contain any spoken words (dances, ora, instrumental performance). So, the only real description of the performance happens in the reading of that overall text, or the situation of the performance allows for the creation of a whole which is created from the obvious and hidden processes of communication. The body of the performer, as presented on the scene is also contingent on the cultural context in the current process of civilization. According to this, the understanding of the performing process in contemporary science is one of the ways to understand the process of human creation of culture. In the end, we should say that the research of the performance is not directed towards the imminent problems in the sphere of art, but towards the problems that refer to the activation of micro politics, and their systems of presentation are a reflection that can be seen though the practice of performance. In this way the performance is seen as a medium between traditional knowledge and imagination, experience and art.

Instead of a conclusion we're going to say that in the wealth of forms and means of expression, folklorists find a constant provocation for the research of rituals related to Rusalian dances, but also no less important and interesting are their performances and most of all the way in which they realize traditional dances related to them. That's why I'll end by sharing the thoughts of Williams (Williams 2006, 35), according to whom society should encourage the institutions to set aside means for the preservation of 
tradition and to defy the criticisms that in some periods claim a strong conviction that the work of these institutions is useless and unimportant. Changes are necessary as well as the creation of new institutions, but if we correctly understand them as a process of selective tradition and view the period which is long enough to get an impression of the historical changes and the volatility of the values of the aforementioned, it should still continue its uninterrupted flow. Oral tradition, whose span is wide, should be valued more and the opportunities which oral folk culture gives us should be appreciated, so that the lavish well doesn't dry up.

\section{References}

Bendix, Regina. 2007, "Kulturelles Erbe zwischen Wirtschaft und Politik. Ein Ausblick." in Prädikat "HERITAGE". Wertschöpfungen aus kulturellen Ressourcen, ed. Dorothee Hemme, Markus Tauschek i Regina Bendix, 337-357, Berlin: LIT Verlag,

Ceribašić, Naila. 2003. Hrvatsko, seljačko, starinsko i domaće: povijest i etnografija javne prakse narodne glazbe u Hrvatskoj, Zagreb: Institut za etnologiju i folkloristiku.

Чајкановић, Веселин. 1973. Мит и религија у Срба, Београд: СКЗ.

Гошева, Вера. 2006. „Добротворната компонента во русалиските обичаи во јужна Македонија." Македонски фолклор 63: 203-209.

Димовски, Михајло. 1974. „Русалиските игри од селото Секирник (Струмичко) и нивните карактерстики." Македонски фолклор 13:165-183.

Димовски, Михајло. 1975. „Русалиските игри во селото Богданци (Гевгелиско)." Македонски фолклор 15-16: 159165.

Јаневски, Владимир. 2013. Етнокореолошки карактеристики. На македонските народни ора. (по избрани примери). Скопје: Институт за фолклор „Марко Цепенков“. 
Јанковић, Љубица и Даница. 1948. Народне игре, књига IV, Београд: Просвета.

Кличкова, Вера. 1969 „Русалиски обичаи во Гевгелиско.” Македонски фолклор: 377-385.

Ivančan, Ivan. 1967. Narodni običaji Korčulanskih kumpanija, Zagreb: Institut za narodnu umjetnost.

Kirshenblatt/Gimblett, Barbara. 2013. "Svjetska baština i kulturna ekonomija." in Proizvodnja baštine: kritičke studije o nematerijalnoj kulturi, ed. Marijana Hameršak, Iva Pleše, AnaMarija Vukušić, 65-117, Zagreb: Institut za etnologiju i folkloristiku.

Lešćak, Milan. 1992. The Stylization of Folklore and Present Folklorism. in Folklore, Folklorism and National Identification - The Slovak Cultural Context, ed. Gabriela Kiliánová, 5-14, Bratislava: Slovak academy of Science.

Mukaržovski, Jan. 1987. Struktura, Funkcija, znak, vrednost, Beograd: Nolit.

Шапкаревъ, Кузман. 1884 Руссаллии, древенъ и твьрдъ интересенъ българский обичай, запазенъ и до днесь въ Южна Македония, Търговска Печатница: Пловдивъ.

Шапкаревъ, Кузман. 1891 Сборникъ отъ Български народни умотворения, VII, София.

Rihtman-Auguštin, Dunja.1978. "Folklor, folklorizam i suvremena publika." in Etnološka tribina: Godišnjak Hrvatskog etnološkog društva 7-8(1): 21-28 https://hrcak.srce.hr/80008, Accessed February 16,2017.

Тановић, Стеван. (1955-1957) „Народни ора у околини Ђевђелије." Гласник Етнографског института СAH, IV-VI :261-302.

Толстој, Никита Иљич. 1995. Језик словенске културе, Ниш: Просвета. 
Williams, Raymond. 2006. „Analiza kulture.” U Politika teorije. Zbornik rasprava iz kulturalnih studija, ur. D. Duda, 35-59. Zagreb: Disput.

Васиќ, Оливера. 2012. „Русалиски поворки - сличности и разлики со други поворки." Годишен зборник 3(3): 155159. 

III. (POST)MODERN GAMES AND RITUALS 

UDK $39+793.2$

DOI: 10.33876/978-542-110-238-0/135-152

Aleksandar Krel

Jadranka Đorđević Crnobrnja

\section{THE CELEBRATION OF CHILDREN'S BIRTHDAYS IN BELGRADE AND CONSUMER SOCIETY}

In this paper, we analyze the celebration of children's birthdays, the extremely widespread and significant form of social and/or cultural practice in Belgrade, the capital of the Republic of Serbia. This type of social practice, the base of which is the family, was imported from Central and Western Europe to Belgrade between the First World War and the Second World War. The celebration of children's birthdays achieved its full affirmation in the second half of the 20th century, when it became one of the most important family holidays in both urban and rural areas. It manifested concurrence with the characteristics of the consumer society even in the time of the socialist period, and in particular it fully coincided with the predominant ideal of the consumer society when the post-socialist Serbian society took a neoliberal political course. Despite some changes that mainly relate to the place and way of celebration, the very essence of this social practice has not been drastically changed. In this paper, we are trying to consider the role of birthday celebrations in Belgrade in the context of current economic, social and cultural circumstances.

Key words: children's birthday, birthday celebrations, consumer society, Belgrade, Serbia

INTRODUCTION. In this paper* we analyze the celebration of children's birthdays in Serbia, more precisely in its capital city. It is

* This paper presents the results of the research by Aleksandar Krel on the project: „Multiethnicity, Multiculturalism, Migration - Contemporary Processes" (No. 177027) and research conducted by Jadranka Đorđević Crnobrnja on the project: „Interdisciplinary research on the cultural and 
a widespread and very important form of social and cultural practice in Serbia and its capital. After attending the celebrations of children's birthdays, we concluded that the place and manner of their celebrations have changed significantly from the period of our childhood (the 1970s and 1980's). In the memories of our generation, our birthday celebrations and the birthday celebrations of our peers have become a synonym for entertainment organized in the homes, and their primary entertainment content was dances accompanied by the sounds of popular musical hits emitted mainly from the gramophone. The serving for the guests were sandwiches, sweets, soft drinks and unavoidable cake with crayfish birthday candles. Unlike the previously described manner of celebration, today children's birthday parties are celebrated differently. They are not organized in the homes so much, and in most cases, they are celebrated in playrooms, specialized spaces offering a wide range of entertainment and catering services for both children and adults. Seeing the transformation of children's birthdays during the last decade, we decided to conduct research about it in order to determine the social, economic, political and cultural factors that caused it.

The determination to deal with this topic is further strengthened by the fact that our colleagues, Miroslava Malešević and Dobrila Bratic, conducted research about children's birthdays in the area of Priboj and Bajina Bašta at the beginning of the 1980s, thus introducing this topic into Serbian ethnology and anthropology. Based on the analysis of the empirical material that they collected during their research, they wrote and published a coauthored article which is considered a pioneering scientific paper about this type of social practice in Serbia (Malešević and Bratić 1983). Thanks to their research, we have insight into modalities and the broader social, political and cultural context of celebrating children's birthdays at the end of the century, as well as the current theoretical and methodological approach to this topic. Reading their

linguistic heritage of Serbia and the creation of a multimedia internet portal Glossary of Serbian Culture" (No. 47016). Both projects are fully funded by the Ministry of Education, Science and Technological Development of the Republic of Serbia. 
article from a distance of more than 30 years, and bearing in mind the memories of our childhood birthday celebrations, we decided to identify the causes that led to certain transformations in the way and content of the celebration of birthdays today, while taking into account the turbulent political, economic, social and cultural changes in Serbian society which happened in the past few decades. Unlike our predecessors, we decided to start our research in Belgrade for several reasons. One of the reasons for our decision is that in Serbian ethnology and anthropology no one has conducted research about children's birthday celebrations in the capital city. The plan is to expand the research to other urban areas in Serbia when conditions are met ${ }^{1}$.

THE CELEBRATION OF CHILDREN'S BIRTHDAYS IN BELGRADE BEFORE THE BREAKUP OF THE SFRY. The celebration of birthdays whether for children or for adults - did not exist among the mostly Serbian population inhabiting present day Serbia before the mid$20^{\text {th }}$ century. Precise data on the first birthday celebrations in the mentioned area are not known, but it can be assumed that this social practice in Serbia and Belgrade was most likely imported through the economic and cultural contacts made between the Austro-Hungarian Empire and the Kingdom of Serbia at the end of the 19th and the beginning of the 20th century, and later through the cultural contacts between the Kingdom of Serbs, Croats and Slovenes (SHS) with France and Great Britain after the end of the First World War (see Timotijević 2006, 542-543). Expanding from the western parts of the Kingdom of SHS to its eastern and southern

1 The empirical part of the research involved conducting interviews with interlocutors (semi-structured interviews) who live in Belgrade. We interviewed parents between the ages of 30 and 50. The interlocutors talked about their own experience of organization of birthday celebrations for their children. Empirical material addresses the celebration of children's birthdays for the past 10 years, as well as the birthday parties that were organized during the years when we conducted our research (2016 and 2017). The research that we started in 2016 is in progress. The work is based on the empirical material on the celebration of the birthdays of children of pre-school and school age (up to the fifth grade of elementary school). 
parts, this aspect of social practice was first accepted among the urban population, more precisely among its richest and educated population, namely the social elite (Timotijević 2006, 542-543).

Only after the end of the Second World War, after the establishment of a socialist political organization, the celebration of children's birthdays slowly began to lose the epithet of elitist privilege and became a massive phenomenon (Malešević and Bratić 1983, 87). At that time it took on the appearance it has today (Ibid.). The causes of the popularization of this social practice should be seen in the light of the radical social, economic, political and cultural changes that have occurred to Yugoslav society in the mid-century. The leaders of the Communist Party of Yugoslavia recognized in the celebration of birthdays the ideal secular ritual, which could serve as a substitute for the religious family ceremonies characteristic for childbearing (for example, baptisms). Consequently, it became a socially desirable form of behavior, in the service of a powerful antireligious a campaign led by the ruling structures with the goal of secularization of the state (see Malešević and Bratić 1983, 88-91). The popularization of children's birthday celebrations is reinforced by the fact that all the state institutions which were involved in the upbringing and education of children and youth, from kindergarten, primary school, to high schools, supported this aspect of social practice, and often the very celebrations took place in their buildings. In this way, through the professional care of educators, teachers and professors, social control and the institutionalization of this custom was carried out ${ }^{2}$. In the 1980's, due to the favorable social climate, the celebration of children's births had become one of the most important family holidays, not only in urban, but also in rural areas (see Malešević and Bratić 1983, 88-91). Analyzing the popularization of the celebration of children's birthdays in Serbia in the second half of the 20th century, Malešević and Bratić noted that this practice was accepted by many families not only because of the

2 Institutionalizing childhood is a process in which society through the institutions and educational system influences the social life of children. Though this process, children adopt new contents aimed at their social control and channeling them towards the manifestation of socially desirable forms of behavior (Tomanović 2004, 116-117). 
mere effort "to adapt to the ideological climate of the times" (Malešević and Bratić 1983, 89) but also because "the abolition of traditional religious festivals has led to the impoverishment of social family life" (loc.cit.). In this regard, they observe that children's birthday celebrations are an opportunity to "maintain the continuity of those social relationships that were realized through family gatherings" (loc.cit.). They note that, through birthday celebrations, families simultaneously "send a message to the social community about the degree of their prestige" (Malešević and Bratić1983, 94) and "express love and attention towards the child" (loc.cit.); and that the degree of the love is expressed in the amount of money spent on the organization of the birthday and in the complexity of its content (see Malešević and Bratić, 1983, 89, 94). Their conclusion confirms the assumption that the Yugoslav socialist society (ie. Serbian, as a part of it) basically is a society determined by consumption (Malešević and Bratić, 1983, 98) 3 .

The increase of social standard in socialist Yugoslavia was due to the credits from the West (primarily from the United States) obtained as an expression of their support for the political struggle of the Yugoslav leadership against the Soviet Union. This "process of reducing ideological differences with the Western countries" (Erdei 2012, 64-65) plays a very important role in the formation of a consumer society in socialist Yugoslavia (Erdei 2012, 64-65). Since the 1960s, there has been a significant increase in the living standards of its population, and the consumption of industrial products (footwear, clothing, household appliances, radio and TV, cars etc.) has seen a significant increase (Zindhauzen 2008, 389).

3 The idea of a socialist society as a "consumer" is in the anthropology was advocated by a certain number of authors. For example, Zigmunt Bauman and Deniel Miller insist on the difference between concepts of consumption and consumerism. They believe that consumption is a phenomena or a cultural constant which is present in all societies, however, consumerism indicates the degree of development of a society characterized by its consumption which becomes the primary meaning of human existence (see Erdei 2012, 25-27). Consequently, we can talk about consumption in socialism and consumerism in neoliberal capitalism (cf. author). 
CHILDREN'S BIRTHDAYS AND CONSUMER SOCIETY IN BELGRADE. Dramatic political, social, economic and cultural changes, and the complex international political situations that Serbian society faced in the last decade of the $20^{\text {th }}$ century and the first decade of the new millennium, among other things led to a "social transformation" (Erdei 2012, 99); it as in other countries of the former Eastern Bloc, conditioned the "transition from planned to liberal market economy" (loc.cit). This course of events and the development of a consumer society that was subsequently followed in Serbia, and then continued during the transition period ${ }^{4}$, led to the emergence of consumerism in it.

Observing the place, the means of celebrating and the content of children's birthday parties in Serbia and comparing the way they were marked in the past with the practice in the present, it can be noted that they experienced modifications and transformations. The celebration of children's birthdays in the 1950's (conditions of general material shortfall in the country marked the first postwar decade) took place in the narrow family circle, with modest services and gifts which had more symbolic than material value (Malešević and Bratić 1983, 88). Both in urban and rural areas, the means of celebrating in the 1980's bring a greater number of guests (the number of friends and colleagues is in evident increase compared to the relatives). Choice of meals and beverages, as well as the modes of parties became more diversified, and it is noticeable that more valuable gifts are given, especially when celebrating jubilee birthdays: first, seventh and eighteenth. For these birthdays, besides jewelry, significant sums of money were often given, and the sum was determined by the degree of closeness of kinship between celebrant and relative; this is in accordance with the patriarchal principle of family and kinship relations that were in place at that

4 Moris Godelie used the term transition in anthropology to describe complex social and economic relations during the transition from feudalism to capitalism, and in today's discourse it denotes a process in which the former socialist states in Eastern Europe (since 1989) reject the concept based on totalitarianism, autocracy and planned economy and gradually accepted, a model of a society based on democracy, pluralism and a developed market economy (see Erdei 2012, 112-113). 
time (see Malešević and Bratić 1983, 92; Đorđević 2000, 37-48). Birthday celebrations correspond to changing lifestyles and cultural preferences of the population and represent behavior patterns conditioned by consumption.

One of the striking differences in the manner of celebrating birthdays in the past and today is certainly the practice of a birthday celebration outside of the house. It began in the time of socialism (Malešević and Bratić 1983, 92-93), and organizing parties at McDonald's ${ }^{5}$ contributed to its popularization in the 1990's in Belgrade. The first restaurants of the world-famous fast food chain McDonald's were opened in the late 1980's in Belgrade, in two locations in the city center, in Slavija and Terazije. In addition to the basic catering activity that brought it global popularity, this American company offered the opportunity to organize children's birthdays as a part of its program aimed at young consumers. Birthday celebrations at McDonald's in Belgrade soon became very popular among all their actors. For parents the organization of children's birthdays was significantly easier, since the care and the entertainment of the guests were entrusted to the employees of the restaurant. In addition, the use of space and children's animation were free. The parents were obliged to pay for the food and drinks consumed by the guests. The celebrant was also given a birthday gift from the company. In addition, parents did not have to worry about the safety of their own furniture or that their guests would adulterate their homes.

This kind of birthday celebration has gained great popularity in our capital, not only because of the advantages described above, but also because it can be interpreted at the symbolic level as the identification of its organizers ${ }^{6}$ with the capitalist way of life and the

5 A similar situation was recorded by colleague Vesna Petreska in Skopje (2007, 167-176; 2008, 73-91). On this occasion, we sincerely thank V. Petreska for informing us about her research and published results.

6 This term we use in this article refers to parents of children and other relatives involved in supporting parents (most often grandparents of celebrant), and not professional organizers employed in agencies that provide these types of services and activities. 
achievement of the "American dream"7. This is also supported by the fact that only wealthy citizens could afford this kind of celebration, because at that time it cost a fair amount of money, which a small number of people could afford. Along with the increase of the social standard in Serbia, at the end of the $20^{\text {th }}$ century, an increasing number of parents opt for this type of birthday celebration for their children ${ }^{8}$. If we consider a birthday celebration at McDonald's as a socially constructed act of consumption, it can be said that it becomes a consumer good, more precisely, the mode by which consumers (its organizers, and to a certain extent all actors), express themselves and participate in the returning of meaning to their own existence (Ože 2005, 154). This form of celebration of children's birthdays was a kind of symbolic herald of the democratization of Serbian society and introduction of the changes that will take place in the decades which followed. The birthday parties at McDonald's additionally stimulated the process of relocating the celebrations from the home of the celebrant, which is today considered a normal phenomenon.

At the end of the first decade of the $21^{\text {st }}$ century the arrival of the first playrooms - specialized spaces for birthday celebrations caused a decline in the interest in birthday parties at McDonald's. This claim can be supported by changes within the spatial distribution at Mc Donald's objects. Spaces that were designed for birthday celebrations were large enough to accommodate a large number of children (twenty and more) and adults. Along with the reduction of interest for their renting, these spaces are reduced. These spaces are transformed into miniature rooms that sometimes cannot accommodate more than ten children. McDonald's birthday parties at that time were less expensive than celebrations at the playrooms. Thus, they become a symbolic expression of the fall in the purchasing power of the parents. In the second decade of the

${ }^{7}$ About the emergence of the process of the development of consumer society, consumerism and the phenomenon of Americanization, expressed through the idealization of the image of the USA in Europe and its appearance in Yugoslavia, see Vučetić 2012, 351-352.

${ }^{8}$ A similar phenomenon was noted by colleague V. Petreska in Skopje (Petreska 2007, 167-176; 2008, 73-91). 
21st century, the birthday celebrations at McDonald's are slowly increasing in popularity, but their "classical" birthday celebrations are still less expensive than celebrations at the playrooms. In addition, the "classic" way of celebrating birthdays at McDonald's is not particularly accepted as a right kind of the entertainment for the children of school age, especially children older than 10 years, because the content is too modest and not attractive enough for them. They are happy to accept birthday parties at McDonald's as an additional program which is after a cinema show and involves only the consumption of food and beverages that are sold at McDonald's restaurants, which are not losing popularity among children of that age. For such a way of the celebration, no special room and animator are required.

Today the celebrations of children's birthdays in Belgrade, except in extremely rare cases, are held outside the home of the celebrant. The most common spaces are the children's playrooms, specialized spaces for children's entertainment. Such a trend can be interpreted in the context of the continuous development of commercialization of childhood in Serbian society ${ }^{9}$, where celebrations of children's birthdays are recognized as a good opportunity for making profits. A number of entrepreneurs, who bought out the shops of former trade and catering companies in the process of transition, came up with the idea of adapting them to celebrate children's birthdays. Recognizing the needs of their potential clients, the owners of the playrooms have made sure that apart from the space for celebration, they provide a variety of entertainment and take on all the details of birthday party organization. Parents, burdened by the pressure of daily duties and due to the lack of time, often decide to organize birthday celebrations in such places.

If somebody decides to organize a celebration either in the home or in some other place, they have at their disposal companies engaged in the sale of items that serve for the decoration of space

9 The commercialization of childhood in Serbia, begun in the time of socialism, takes its full expression in the period of post-socialism, showing its full market potential (see Erdei 2012, 73-89, 246). 
and birthday cakes (balloons, confetti, sprinklers, magic candles, fireworks etc.). The possibility of selecting everything and buying it in one place shortens the time needed to organize the celebration. For this reason, the celebrations of children's birthdays, especially the first and the eighteenth, are considered to be very lucrative in Belgrade today and there is an evident increase in "small factories of entertainment" specializing in making these kinds of products. Based on the empirical material we collected during interviews with our interlocutors, we have come to the conclusion that today's parents spend between 350 and 3,000 Euros on such celebrations, and that the average birthday party lasts for three hours. It includes animators who take care of children's entertainment. How much money will be allocated for birthday celebration depends on what its organizers want to achieve, or which message they send to the public. If they only want to mark that day, then its celebration is organized in an economically rational way, and consumer practice is in line with their financial capabilities. In anthropological theory, this type of consumption is designated as "not exposed" (Erdei 2008, 352).

In some cases, parents are able to recover the funds invested in the celebration. However, the return of the invested funds and the possible financial gain do not happen often, because it is very difficult to make a precise financial calculation of the celebration that would enable it. Asked if he managed to recover the money invested in the birthday party of a child one of our interlocutors says:

"If we take into the account the cost of a gift to the child, as well as for her clothes, we spent over a thousand Euros for her birthday. Some guests gave clothes, some money, mostly those whom we gave money for birthday. We've managed to get some money back in this way, but not the whole amount. Maybe 
around 500 euros, a little more. Of course, grandparents also helped financially"10.

Such consumer practice can be somewhat viewed as an expression of economically rational. However, our empirical material about children's birthday celebrations also points to the fact that more money is spent for children's birthdays than we would expect from parents if we take into consideration their salaries. Employees in education, doctors, and officials opt for celebrations that have the elements of the gala ceremony. This kind of celebration is more frequent when it comes to the first birthday of a child or with a jubilee birthday. The organization of such celebrations requires increased financial costs because it involves special clothing, shoes, hairdresser and make-up for the celebrant and parents, a band, a greater number of cakes, smoke makers, magicians, etc. Not so rarely, due to exceeding their own economic limits, parents accept financial assistance from close relatives (most often grandparents), or borrow from friends, and we reported cases when parents decided to take a loan in the bank. Justifying such actions, some of our interlocutors made the following comments:

\begin{abstract}
"Our child is not worse than other children. Many tell us that for that money we could go somewhere for a holiday. My spouse and I saved the money for her first birthday. We wanted to afford that day, that's our right." 11
\end{abstract}

"We are not exactly in the situation to spend our money recklessly. Simply, it was my desire, because I enjoy the aesthetics - the look of the cake, the decoration of the table, the clothes, the space. We wanted to have a

10 The interview was conducted in Belgrade in 2016. The interlocutor (male, 41 years) speaks about the celebration of the sixth birthday that they organized in 2016 in Belgrade.

11 The interview was conducted in Belgrade in 2016. The interlocutor (female, 34 years) talks about the birthday that they organized in 2016. 
beautiful memory, so we tried to make it beautiful as much we could."12

These examples of consumer practice are not based on economic rationalism. They represent the expression of "expended consumption" (Erdei 2008, 365), based on the ethics of wastefulness. Such consumer practice does not aim to return the invested funds, because its logical principle is that the amount of money invested in the organization of a birthday party is proportional to the social reputation that hosts could acquire in the wider social circle. This means that organizers could enjoy a greater social status in the eyes of the guests if they provide diverse entertainment content and a diverse range of food. It follows that social behavior is represented in the function of "accumulation of social and cultural capital" (Erdei 2008, 365). In addition, the aforementioned examples confirm how consumption is socially conditioned and its multi-dimensional nature, as it meets the different needs of consumers. In this case, it is noted that organizers of children's birthdays simultaneously look for self-affirmation and enjoyment (see Erdei 2008, 360-364). Such consumer practice enjoys an expansion at the time of consumerism, in which consumption becomes, among other things, a polygon for expressing its own social status. In such social and economic conditions, as the children are getting older, their demands grow increasingly because they are surrounded by meanings and social values that are determined by consumerism ${ }^{13}$. In that sense, a modern (consumer) society, dependent on consumption, seeks to ensure that each individual is, in childhood, "educated" in the spirit of a good consumer, that is, turning it into a predictable consumer (Vujačić 2017, 25). Parents and children also expressed the need to imitate the lifestyles of higher social classes, that is, to strive for it. A part of the statement of one of our interlocutors testifies to this:

12 The interview was conducted in Belgrade in 2017. The interlocutor (female, 36 years) speaks of the celebration of the first birthday that was in 2015.

13 About the relationship between consumerism and life preferences, see Vujačić 2017. 
"When our daughter was younger, she was at the age of ten years; she was going to an acting school together with the daughters of the owner of one TV station in Belgrade. One of them invited her to a birthday party. The child was fascinated by the various details such as cake, clothes of the invited children. She was impressed the most by a fountain from which flowed liquid chocolate, which the children could consume in an unlimited quantity."14

Others, in the desire to impose their own taste, are feverishly searching for the most original way to celebrate the birthdays of their children. Accordingly, new places for birthday celebrations appear. It's a recurrence of so-called adrenalin zones, such as a carting track, a "laser tag" game room, a free-climbing spaces and the like. This tendency, in addition to the competitiveness of the cultural preferences for providing as much as possible for a birthday celebration, and an increasing tendency to raise birthday standards, allows the owners of playrooms to profit (see Erdei 2008, 351).

However, somewhat unexpectedly, in our empirical structure, there are also examples of the reduction of birthday celebrations in Belgrade. After several decades of long-standing practice of birthday celebrations, this phenomenon is in direct relation to the decline of the living standards in Serbia. It is expressed in the form of a merging of birthday celebrations, their organizing in the home of the celebrant or in an open space. The celebration of a child's birthday in the home of a celebrant or in a public open space (in the park, for example) is not in all situations the consequence of the financial incapacity of parents to organize their birthday in a playroom or in any other place designated for that, but rather as an expression of their desire to act contrary to the stable forms characteristic for the consumer society and consumerism. We note that there are increasing numbers of birthdays celebrated on the same day when parents have more than one child whose birthdays

14 The interlocutor (female, 48 years) speaks of the birthday that was six years ago. The interview was held in 2017. 
are in a short time span (two to three months) and if they are similar in age. The examples that we recorded also show that birthdays can be celebrated together with classmates if they were born in the same month and if they are friends, or if their parents are ready for such a type of organization. In this case, the parents share the expenses for the celebration of the birthdays. The birthday celebration does not lose much of the content, the number of guests may increase, but the costs are decreasing. Empirical material shows that for renting a space for a celebration, more money is needed than for other content that accompanies the celebration ${ }^{15}$. Besides, we recorded another form of reduction in relation to birthday gifts. One of our interlocutors in relation to this practice pointed out the following:

"A group of four children has been formed, who attend the same school class with my younger daughter and who are friends with each other. When one of them calls the rest for his birthday, the parents of his friends set aside 10 euro banknote and that banknote is his birthday gift. Each of the children invites all children from the formed 'birthday circle', so that the same monetary value is practically exchanged between to them, and the reason for this is a 'difficult material situation' because some of the parents of these children 'barely meet their ends'. For this reason, the parents, whose financial situation and opportunities are better, decided to be in solidarity with those who are poorer and their children do not differ from each other in the amount they give to each other." 16

This phenomenon can actually be characterized as a kind of economic exchange between parents, which takes place in the form of a gift among children, and by which their mutual social connection is consolidated and maintained (Staton-Smit 1989, 31).

15 Renting a space for the celebration of birthday, as well as a renting playroom (for two or two and a half hours) ranges from 40 to 100 Euros.

16 Interlocutor (female, 46 years old) talks about the period 20142016. The conversation took place in 2017. 
In this case, through a birthday gift, a 10 euro banknote, a group will be formed, which will last for as long as its members are interested in participating in it. We also note, that in some cases as in this one, the economic unification of members of the birthday community is carried out, as its financially stronger members have expressed solidarity with the materially weaker members, expressing their readiness to accept the previously agreed material value. Merging birthday celebrations and donations are not that common so that we can talk about a general practice. Nevertheless, they reinforce the claim that the celebrations of children's birthdays are determined by economic factors and can be interpreted only in the current social, economic and cultural context.

CONCLUSION. In this paper we analyzed the social practice of celebrating children's birthdays in Serbia and Belgrade, both in the past and in the present. We gave a brief historical overview of the emergence of this social phenomenon, analyzing the main reasons for its transformation, and presented the preliminary results of our research. Analysis of the organization, content and places where the celebrations are held in Belgrade, is viewed in the social, economic and cultural context, and is based on the literature and empirical material which authors collected. It points us to the following conclusions:

- The birthday celebrations as a form of social practice had a dual function: love and attention were expressed to the children, but at the same time they weighed homogenization of members of family, relatives and friend networks.

- The celebration of children's birthdays in Serbia and Belgrade was popularized for ideological reasons. A favorable environment for its popularization has been created in society, so that already in the 1980's, the child's birthday was celebrated as one of the most important events in the holiday calendar of a significant part of the population in Serbia, and that not only in the urban areas, but also in the rural areas.

- These celebrations preserve the nature of the events that communicate the message of love to the children, but also to the 
children of the relatives, friends, business partners, and in the age of neoliberal capitalism, they are increasingly turning into a spending festival.

- We have noted that the empirical data collected in our research so far corresponds, to a certain extent, to Bourdieu's idea of the convertibility of the four different forms of capital. ${ }^{17}$ If we were to mark the sum of money spent on the celebration of a child's birthday as an economic form of capital, or as a "effectively available resource of power" (Bourdieu 1979, 128, see Spasić 2004, 289), following Bourdieu's idea, the space in which it takes place, the number of guests, and the entertainment available make up its symbolic expression, or symbolic capital. Thus, the choice of place and mode of celebrating birthdays actually represents a kind of strategy the organizers utilize in order to - through the transformation of economic into symbolic capital - maintain or enhance their own position, not only among the guests but within the wider community. Because of this, the amount of effort put in by the organizers in picking the right place to have a birthday party is not surprising. Mostly, they chose specialized playrooms which offer exclusive entertainment for the guests, or choose places and ways of entertainment which have already been approved by, or became popular among children. The celebration of children's birthdays in Belgrade, as a form of social practice, is actually utilized as a complex information system which serves to display, to the wider community, the economic, social and cultural capital of its organizers.

\section{References}

17 French sociologist Pierre Bourdieu uses the concept of capital to denote "all goods, both material and symbolic, which are displayed as rare and worth striving toward in a given social formation" (Bourdieu 1977, 178, see Spasić 2004, 289). In the concept of capital he sees many meanings and differentiates between its four basic forms (economic, symbolic, cultural and social). Bourdieu believes that capital, in accordance to certain rules which govern a given "field", can be transformed from the economic sphere and can be displayed in the spheres of culture, social relations or on the symbolic level (see Spasić 2004, 289-290). 
Bourdieu, Pierre. 1977. Outline of a Theory Practice, trans. by Richard Nice. Cambridge: Cambridge University Press.

Bourdieu, Pierre. 1979. La Distinction. Critique sociale du jugement. Paris: Editions de Minuit.

Vučetić, Radina. 2012. Koka-kola socijalizam. Amerikanizacija jugoslovenske popularne kulture šezdesetih godina 20. veka. Beograd: Službeni glasnik. Biblioteka društvo i nauka. Edicija istorija.

Vujačić, Lidija. 2017. Antropologija konzumerizma. Život (ni)je u reklami. Medijska kultura 13. Nikšić: Biblioteka - Teorija medija.

Ђорђевић, Јадранка. 2000. „Обичаји о рођењу и сроднички односи у Врању." Зборник радова Животни циклус у периоду кризе - Реферати бугарско-српског научног скупа одржаног у Софији од 12. до 16. јуна 2000: 37-48. София: Етнографски институт с музей БАН.

Зиндхаузен, Холм. 2008. Историја Србије од 19. до 21. века. Београд: Clio.

Erdei, Ildiko. 2008. Antropologija potrošnje.Teorije i koncepti na kraju XX veka. Beograd: Biblioteka XX vek.

Erdei, Ildiko. 2012. Čekajući Ikeu. Potrošačka kultura u postsocijalizmu i pre njega.Beograd: Srpski Genealoški centar i Odeljenje za etnologiju i antropologiju Filozofskog fakulteta u Beogradu.

Малешевић, Мирослава и Добрила Братић. 1983. „О прослављању дечијих рођендана." Гласник Етнографског института САНУ XXXII: 87-99. Београд: Етнографски институт САНУ.

Ože, Mark. 2005. Prilog antropologiji savremenih svetova. Beograd: Biblioteka XX vek.

Петреска, Весна. 2007. „Прослава на детски родендени - нова форма на обредност." Македонски фолклор XXXIII (64): 167-176. 
Петреска, Весна. 2008. Етнографија на современиот семеен живот во македонското семејство. Посебна изданија, 70: 73-91. Скопје: Институт за фолклор „Марко Цепенков”.

Spasić, Ivana. 2004. Sociologija svakodnevnog života. ur. Anka Jakšić. Beograd: Zavod za udžbenike i nastavna sredstva.

Staton-Smit, Brajan. 1989. Igračke i kultura. Beograd: Zavod za udžbenike i nastavna sredstva.

Тимотијевић, Мирослав. 2006. Рађање модерне приватности. Београд: Clio

Tomanović, Smiljka. 2004. Sociologija detinjstva. Sociološka hrestomatija. Beograd: Zavod za udžbenike i nastavna sredstva. 
UDK $39+327+347.514 .3$

DOI: 10.33876/978-542-110-238-0/153-177

Ivan Đorđević

\section{Politics on the Football Field. AN OVERVIEW OF THE RELATIONSHIP BETWEEN IDEOLOGY AND SPORT IN SERBIA}

This paper focuses on the historical context of the interrelation of sports and ideology in Serbia. Firstly, it focuses on the period between the end of WWII and the end of the 1980s, as well as on the role of sports in the activities of the communist and socialist ideology in Yugoslavia. Secondly, it demonstrates the ways in which football fans assumed the role of the carriers of nationalistic ideology in the political occurrences of the final decade of the twentieth century. The third segment of the paper brings into focus the activities of football fans in the new millennium when, after the wars of the 1990s, Serbia, at least nominally, became a state that internalizes "European values", and ensured its position of an EU-acceding country. The central argument of the paper refers to the historically conditioned positioning of football fans that, as a group, still hold the role of an important political actor. They simultaneously act as subjects of the neo-liberal politics of the European periphery and keepers of the "national spirit", which can be let out of the bottle again, if and when needed.

Keywords: Serbia, former Yugoslavia, football, ideology, socialism, postsocialism

Sport, especially football, and its relation to the complex societal process in Southeastern Europe and Serbia has become a prominent research subject of numerous disciplines in recent years. A significant volume of books, articles, and publications have approached this subject from their own unique position, aiming at disclosing and determining the role sport played in the historic developments surrounding the dissolution of Yugoslavia. 
Indeed, football had a significant symbolic role in the process of the disintegration of SFRY. It was used as a peculiar type of catalyst in the shift of the ideological paradigm from the concept of the "brotherhood and unity" of Yugoslav peoples to individual ethnic nationalisms, breaking down the pillars of the post-WWII state. In the late 1980s, football fans across the territory of former Yugoslavia embraced nationalist ideology and introduced thus far unimaginable messages of ethnic intolerance into the public space, messages that were expressed week after week at the stadiums. The culmination of this process was reached on May 13, 1990 at Maksimir stadium. Namely, ahead of the match between Dinamo Zagreb and Red Star Belgrade a large clash between their fan groups and the police occurred (Brentin 2013; Đorđević 2012). Croatian and Serbian fans, determined to replace verbal with physical violence, confronted the police, which proved powerless in their attempt to prevent this escalation. Essentially, the scenario unfolding at the stadium in the Croatian capital symbolically pointed to the denouement of the culminating Yugoslav crisis, which would reach its peak during the 1990s in the armed conflicts in Croatia and Bosnia and Herzegovina. Even though the armed conflicts started a year later, the riots at Maksimir are perceived in both Serbian and Croatian collective consciousness as the "day when the war began" (Mihailović 1997).

The Maksimir riots had one important consequence in terms of the relation(s) between football and politics. From that moment onward, football became permanently contaminated by nationalistic ideology ${ }^{1}$, and football fans of the two respective countries assumed the role of an important political factor, drawing their legitimacy from "patriotic" capital, formulated by their participation in the events of the late 1980s and early 1990s.

However, the involvement of the football fans in the dissolution of Yugoslavia was far from accidental. As noted by Hoberman, "sport may serve any (...) given ideology" (Hoberman

1 Nationalistic ideology was also visible in Yugoslav sport during socialism (Zec 2015), but without ubiquitous presence as it was the case in late 1980s and early 1990 s. 
1993: 16). This is clearly visible in the significant impact level of socialist ideology in determining the framework of sports development in post-WWII Yugoslavia. This feedback relation between sports and ideology often demonstrated all the contradictions of the socialist system, in which football served as a playground for diverse societal and economic experiments of the system. Additionally, the game of football was often used as a factor of homogenization of Yugoslav identity (Zec and Paunovic 2015). Logically, the ideological transformations occurring in the former Yugoslavia were mirrored in football and, in turn, the game had the role of a symbolically important societal segment, a phenomenon that through its mass character, popularity, and omni-presence crucially influenced the stated transformation processes, or at least made them visible.

The main goal of this paper is to point out the historical context in which the intertwining of diverse ideologies and football occurred in Serbia (and former Yugoslavia), and which determined the specific role of this sport in contemporary Serbian society. Through the analysis of football's role in socialist and post-socialist times, I will attempt to highlight the importance of this societal phenomenon in the transformation processes of Serbian society, with special attention given to contemporary occurrences - from the role of football in the creation of the communist "new man", through its position as a messenger of the capitalist relations in a socialist society, to the creation of the nationalistic "avant-garde" and patriotic heroes. Through these stages, football fans transformed into relevant societal actors, and in the contemporary context of Serbian society they are perceived as the "keepers of national interests." This transformation determined football in contemporary Serbia through a specific supra-ideological prism, with an unquestionable nationalistic agenda.

In the first section of the paper I focus on the historical context of the interrelation of sports and ideology in the period between the end of WWII and the end of the 1980s, as well as on the role of sports in the activities of the communist and socialist ideology in Yugoslavia. In the second section I demonstrate the ways in which football fans assumed the role of the carriers of 
nationalistic ideology in the political occurrences of the final decade of the twentieth century. The third segment of the paper brings into focus the activities of football fans in the new millennium, when after the wars of the 1990s Serbia, at least nominally, became a state that internalizes "European values" and ensured its position of an EU-acceding country. The central argument of the paper refers to the historically conditioned positioning of football fans that, as a group, still hold the role of an important political actor. They simultaneously act as subjects of the neo-liberal politics of the European periphery and keepers of the "national spirit", which can be let out of the bottle again, if and when needed.

FROM THE MAKING OF THE "NEW MAN" TO "SELF-MANAGEMENT". The end of World War II instigated a core-transformation of the political and societal system in Yugoslavia. With the victory of the Partizan troops under the leadership of Josip Broz Tito, the final remains of the former Kingdom were gone, and the new socialist system became the official polity of the liberated country. The transformation of the entire state system caused drastic changes in the domain of sports as well. To a certain extent, the new socialist government appropriated the heritage and experiences of pre-WWII Yugoslav sports 2 , but it did primarily lean on the vision based on the ideological pillars and practical models developed in USSR (Riordan 1999; Brentin and Zec 2018: 717). In this respect, the former "bourgeois" teams, especially those from the larger urban centers such are Belgrade and Zagreb, were practically erased, and new teams were established instead (Wood 2013). In 1945, two new football clubs were founded in Belgrade - first Red Star in March, and then Partizan in October, as the official club of Yugoslav Peoples' Army (JNA). Even though the two teams used the stadiums of the pre-war teams Yugoslavia and BSK, no intentional continuity

2 The main reason behind this appropriation is the fact that many of the sporting societies in Yugoslavia before WWII were the core of the workers' movement and closely connected to the Communist Party. Therefore, the relation between the new socialist government and sports had already established some type of continuity. 
was proclaimed by the new teams. On the other hand, a new team was founded in Zagreb in the aftermath of WWII. It is assumed that Dinamo's patrons were the members of the police and stateintelligence structures. The only significant exception in this process was the fate of Hajduk from Split, whose management and players took an active part in the resistance against the Italian occupier and acted as the unofficial "Partizan representation," playing twenty matches on the freed territories during WWII (Wood 2013, 5; Dežulović 2013).

The main motive of the new system was to symbolically establish a new order within this segment of society, not allowing any possibility of continuity with the past societal values, with the past "bourgeois" identity. The new teams established by the pillars of the socialist revolution - the JNA and Alliance of the Antifascist Youth - were to promote the values seen as adequate in the newlyformulated state order. Therefore, following the Soviet model, the general direction of the development of organized sports, football included, was set to their promotion as the main form of leisure time of socialist youth. Through this, sports were to serve as the ideal mechanism for emphasizing the reconciliation and the idea of "brotherhood and unity." Additionally, sports were seen as a means for improving the working and defence capacities of the state. Finally, the organized sports were to serve as a tool for promoting the accomplishments of Yugoslav socialism around the globe, mainly through participation in international sporting events. Essentially, the first postwar period was characterized by diligent application of the Soviet model with the goal of making the Yugoslav "new man" (Zec and Brentin 2018: 718; Mills 2016).

However, this vision of socialist sports was not kept for long. The crisis following the clash between the Communist Party of Yugoslavia and Cominform in 1948 had a crucial impact on all the segments of Yugoslavia's society. One of the consequences of the breach between Tito and Stalin was the abandoning of Soviet models, not only in the political and economic spheres but also in other societal domains, including organized sports. In this sense, the making of the Yugoslav version of socialism caused the abandoning of the centralized models of managing sports, and turned towards 
promoting the idea of "self-management" as the main functioning model of managing organized sports. Expectedly, the application of this model was not successful as the sustainability of sports clubs was far from realistic, even when it came to highly popular sports such as football (cf. Zec and Brentin 2018, Kovačić 2016). Therefore, even if officially independent, sports clubs were closely connected to state structures, and often, to large companies. In this way, their functioning was made possible due to the political and economic support of state agencies.

Nevertheless, the transformation from a centralized model to a significantly autonomous functioning model of sports management resulted in a changed status of players. They were not necessarily amateurs anymore but were granted payment for their performance, as all other workers in the state. These early stages of the professionalization of sports had a crucial impact on the development of football during the years of "mature" socialism, in the 1960s and 1970s.

The split-up between Tito and Stalin did not only have impact on the ways of managing organized sports but also granted them an additional, and in many ways important, ideological and political role. The sport matches between Yugoslavia and USSSR transformed into more than a game. They became a stage for the duel between the "apostate" Yugoslav socialism and its stiff Soviet version. A mere chance led to one such game being played out during the Olympic Games in Tampere (Finland) in 1954. The match attracted a significant level of public attention in both countries, and telegrams of support to the teams were sent by the state leaders, Tito and Stalin, warning the players that this event is more than a football game. It was regarded rather as a matter of highest national interest. The match itself was one of the most spectacular events in the history of the game. The USSR team managed to retrieve the difference of 5:1, equalizing the score in the final fifteen minutes of the playing-time and ensuring a re-match. This result was greeted with exultation in the Soviet media. However, the re-match was won by Yugoslavia with a score 3:1, demonstrating a symbolic superiority of the Yugoslav socialist model. The players were greeted as heroes; nevertheless, they lost the competition finals 
against the national selection of Hungary. However, the faith of the Soviet team was significantly different. As a consequence, CSKA Moscow, the military team which most of the representation's members played for, was dismantled and they were stripped of all the privileges they enjoyed in society until that point (Goldblatt 2007, 341; Anđelić 2014, 113-114; Mills 2016, 1747-1756). The connection between football and politics demonstrated its full potential and confirmed the importance of sports as a tool for promoting Yugoslavia as a state outside of its borders. Additionally, it confirmed the potential sports had in making and reinforcing the internal cohesion of the state.

The economic transformation of football from an amateur activity to a professional sport, occurring during the 1960s and 1970 s, had an interesting impact on the perception of the national football selection as a symbol of Yugoslav identity. Viewed through the political lens, it can be noted that the national football selection was always formed following the "republic key", in which attention was given to the proportional allocation of positions so that each SFRY republic had its representatives, which in numbers were selected according to the size and "importance" of each republic (Đorđević 2015, 50). In practice, the model of "brotherhood and unity" functioned without many obstacles. However, issues lay elsewhere. The World Championship in 1974 can serve as a good example for visualizing the model of managing sports by the means of political influence. The national selection for this Championship grouped a number of highly respected players that were seen as a squad with the potential for great performance. The team was truly "Yugoslav", under the direction of the selectors' team, headed by the successful coach Miljan Miljanić, and by respecting the principles of self-management. The national team promoted both the main pillars of the state's ideology - "brotherhood and unity" - and the unique model of Yugoslav socialism. The squad was strongly supported by the public, setting the bar of their future achievement very high. However, in practice the situation was different. The Yugoslav model of managing football proscribed a rule by which any player younger than twenty-eight was not allowed to play for any team outside of the state borders. Even though the sports market was not nearly as developed as it is today, already at that time the best 
among the players could earn a significant amount of money for their performance and achieve a very sustainable level of income from playing abroad. Logically, the state's prohibition caused a significant level of frustration among the players. Even though they were well paid and privileged within the state, they were denied the right to temporary work abroad, granted by that time to all citizens of Yugoslavia. This relic of the state orchestrated managing of football displayed its shortcomings at the Championship in Germany in 1974. Most of the players of the Yugoslav selection were approaching the age when they were allowed to offer their services to foreign markets, and their real aspirations were well mirrored on the football field. The team effort was replaced by individual display of skills, which led to a complete malfunction of the team and resulted in its elimination in the early phase of the competition (Anđelić 2014, 114-115). Until that point, playing for the national team had been raising unquestionable enthusiasm among the players. However, some serious, mostly financial issues, started to spoil the good team spirit. Even President Josip Broz Tito, after visiting the national squad, concluded that "it would be a good idea to provide additional payment for the players when performing for the national selection" (Wilson 2006, 129). The Yugoslav football selection and the public at this point were not yet shaken by interethnic tensions. Rather, the friction appeared due to economic reasons and announced the coming crisis of the Yugoslav socialist model based on self-management. The political and ideological power of the Yugoslav project was still strong, but on this occasion the first cracks in the system of default solidarity presented themselves on the football field. In the same way, the game and the field were to be the spaces in which the announcement of a different crisis would be made during the 1980s - the crisis with ethnic nationalism at its core.

NO LONGER "BROTHERS". Sunday afternoon in the Croatian town of Split on May 4th, 1980 was reserved for football. On this day Hajduk Split and Red Star Belgrade met at Poljud Stadium for an important match in the champion's title race. At 5 minutes past 3, the Sunday afternoon was transformed into something much bigger 
than football. At that moment, it was announced that the president of Yugoslavia Josip Broz Tito had passed away. Following the official announcement, the players of both teams gathered in center field, many of them crying. The gathered crowd broke into then popular song about Tito, expressing their grief and readiness to keep the direction the Yugoslav leader paved in building the socialist Yugoslavia $^{3}$. Only ten years later, on September 26, 1990, at the same location, the match between Hajduk and Partizan Belgrade showed just how far things had gone in the process of keeping Tito's socialist heritage. The match was stopped due to the attack of Hajduk's fans on Partizan's players. The climax of the riot was the burning of the Yugoslav flag on the highest flagpole at Poljud Stadium 4 .

Similar images from football fields, accompanied by an escalation of ethnic hatred, had by that time become a rather common message sent from stadiums throughout the territory of Yugoslavia. The ten years between the mourning of the loss of the beloved president and the symbolic burning of the state's flag in Split were marked, as stated by Brubaker, by an all-encompassing nationalization of the political sphere of the state (Brubaker 1996, 3 ). Football culture during the 1980s was closely related to the political occurrences in the SFRY preceding the final dissolution of the state. The economic and political crisis which had already entered the stage in the early 1980s only deepened the already existent inter-ethnic tensions among the constitutive nations of Yugoslavia (Glenny 1996; Silber and Little 1996; Gagnon 2004). Football stadiums became the perfect scenery for the escalation of nationalist conflicts. Fans replaced team rivalry with a search for a new enemy, finally found among their peers on "the other side of the border". Fans of the Belgrade-based teams became explicitly Serbian, both in their self-perception and in the gaze of the others.

3 Video available at: https://www.youtube.com/watch?v=gyG7CzJbF HI, accessed: 28.4.2018.

4 Video available at: https://www.youtube.com/watch?v=oJSrjckW-js, accessed: 28.4.2018. 
The same goes for the Croatian football fans in this period. Their agency was strictly defined through the prism of the national question, and the newly discovered ethno-nationalistic discourse was seen as the perfect tool for promoting the ideas of the new nationalistic elites gaining power in some of the Yugoslav republics (Đorđević 2015; Anđelić 2014; Brentin 2013). Nevertheless, the inter-ethnic clashes still remained at the level of verbal expression. However, soon enough violence took on flesh with the already mentioned Maksimir riots in May 1990. The clash among the fans of Red Star Belgrade, the fans of Dinamo Zagreb, and the police marked a symbolic turn in the unfolding of the Yugoslav crisis. During the commentary section following the broadcast of the riots, a television reporter of the Croatian Broadcasting Service warned the audience that what they witnessed was an event which, "if there

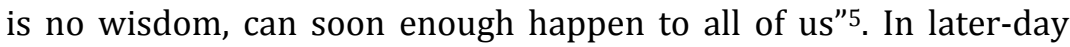
interpretations, the riots in Zagreb were marked as "the day when the war began." and the global impact of this event is somewhat confirmed by CNN, declaring it to be one "of five football matches that changed the world" in $2011^{6}$ (Đorđević 2012, Mills 2009, Mihailović 1997).

The importance of the transformation of stadium stands into bastions of Serbian, Croatian, and other ethnic nationalisms should be firstly related to the high level of the presence of football in the public sphere, as a phenomenon of popular culture. Hundreds of thousands of people at stadiums across Yugoslavia participated, actively or passively, in the rituals celebrating one's own nation. At the same time, through media, millions of viewers participated in the thus far unseen promotion of "new" values, undermining the main pillars of Yugoslavia. The countercultural character of fan groups, among other aspects, allowed for the "forbidden" content to be easily appropriated, and both verbal and physical violence, which

5 Video available at: https://www.youtube.com/watch?v=En6 wViD1jtY\&t=6s, accessed: 26.4 .2018 .

6 http://edition.cnn.com/2011/SPORT/football/01/05/iraq.asia.six. games/index.html, accessed: 5.5.2018. 
were already common during the 1980s among the organized fan groups, instated aggression as the main means of communication. By understanding the potential of football as a means for fulfilling real political and ideological goals, the new political elites in Serbia and Croatia met their coincidental, but very vocal ally, an ally they would use for nesting of the narratives directly opposing the accepted socialist ideology. In these terms, Red Star's winning of the European Cup was used for determining this football team as one of the "pillars of Serbianness" (Đorđević 2016). Similarly, the nationbuilding project in Croatia following its declaration of independence in 1991 was largely based on the employment of sports for promoting the "young" state and nation. Therefore, it can be concluded that, in the context of former Yugoslavia during the 1980 s and at the beginning of the 1990s, football can be defined following Eric Hobsbawm's thought that "an imagined community made out of millions seems more real when represented by eleven people with a name and surname" (Hobsbawm 1992,143).

However, the ethnic-based conflicts between fan groups were not limited only to the stadiums and streets within the borders of Yugoslavia. In the early 1990s, many fans replaced the symbolic wars with the real one, joining the armed formations in Serbia and Croatia. In Serbia, some of the Red Star fans enlisted in the so-called Serbian Volunteer Guard under the leadership of Željko Ražnatović Arkan, later accused of war crimes $^{7}$ (Čolović 2000). Their taking part in active combat on the former Yugoslavia territory caused the permanent colonization of football by politics and the ideology of nationalism. Most of the authors researching this subject interpret this period as the turning point in defining the relations between fan groups and the nationalistic political elites. Furthermore, they emphasize the importance of football culture in the processes of legitimizing the nationalistic agenda in Serbia and Croatia (Foer 2004; Wilson 2006; Mills 2009; Nielsen 2010; Vrcan 2003). In the

${ }^{7}$ Ražnatović was one of the leaders of the Red Star fans during the late 1980s. According to the testimonies of contemporaries, he had an important role in the uniting of heterogeneous groups at the stands into the unified fan group of "Delije". (Đorđević 2015, 98-99). At this point in time they were the carriers of the idea of Serbian nationalism. 
coming decades, football fans gained patriotic capital, as defined by Bourdieu (Bourdieu 1986). By means of the symbolic power they had at their disposal, football fans were granted the role of important advocates regarding the issues of the so-called "national interest", and they were transformed into a significant political force, whose opinion was closely considered during the 1990 s.

"Zvezda, Srbija, niKad Jugoslavija” ["Red Star, Serbia, Never YugOSLAVIA"]. The shifts in the politics of Milošević's regime, especially when it came to the denial of support for the Serbs in Croatia and Bosnia in the mid-1990s, have been perceived as betrayal by the members of the "patriotic public" the football fans belonged to. The interrelation between the war politics of the "rump" Yugoslavia, i.e., Serbia and Montenegro, and the nationalistic ideas of football fans slowly faded. At a symbolic level, this "breakup" was mostly mirrored in the fans' support to the national selection of the rump Yugoslavia. The new state, named Federal Republic of Yugoslavia (FRY) and made as a result of the dissolution of SFRY in 1992, kept the symbols of the previous one, only removing the five-point star from the flag. This ideological continuity, perceived by football fans as the continuity of communist heritage, was a paradigm of Milošević's regime - a paradigm that fluctuated between the socialist values officially appropriated by Milošević's political party and the factual promotion of ethnic nationalism as the dominant ideological pattern in Serbia at that time (Jansen 2005, 20-24).

The state's anthem "Hey Slavs", the official anthem of SFRY, which was kept by the leaders of the rump Yugoslavia, was transformed changed within the frame of the "war of symbols" at the stadium stands, which culminated in the period between 1996 and the fall of Milošević's regime in 2000. The attitude of the Red Star fans toward FRY and its state symbols is most potently expressed by the then extremely popular chant: "Zvezda, Srbija, nikad Jugoslavija" ["Red Star, Serbia, never Yugoslavia”]. The Red Star fan group "Delije" even took an official stand not to support the 
national selection as long as the state carried the name Yugoslavia and kept the coat of arms of the previous state ${ }^{8}$. Furthermore, those fans that did attend the matches of the national selection expressed their discontent during each intonation of the anthem with overpowering booing. Over time, this form of protest against ancien régime was transformed into a potent means of rebellion against the governmental and political power structures. The booing of the anthem was no longer only a means to express "national sentiments"; it became an efficient method for a symbolic clash with Milošević's regime, perceived as anachronous as the symbols of "his" state (Đorđević 2015, 119-120). Due to the appropriation of expression and communication means, football fans presented a powerful political force at the time of overthrowing Milošević's regime in October 2000.

Fans were perceived as a vital ally for the political opposition of that time, endowing the "pro-European" political block with the much needed legitimacy through the "patriotic capital" already won by the fan groups in the previous decade. Additionally, the inclination to violence characteristic of this subculture was more than welcome in the very specific political circumstances, and they assumed the role of the "punching fist" against the repressive state apparatus. In fact, football fans were the only group willing and ready to physically clash with the law-enforcement forces at that point. A good example of such a clash, which carries great symbolic significance, is the Champions League qualification match against Georgian Torpedo at Red Star's stadium in Belgrade, on July 27th, 2000. This game was marked by a large clash between the Red Star fans and the police, as an answer to the police action at the North stands after the first ever performance of the cheer "Spasi Srbiju i ubi se, Slobodane" ["Save Serbia and kill yourself, Slobodan"] . The riot on the stadium marked the beginning of the open war between the Red Star fans and Milošević's regime, and the mentioned cheer became the unofficial anthem of the protest against the state system, resulting in the "revolution" of October $5^{\text {th }}, 2000$. Football fans played a significant role in the protests following the attempt of

${ }^{8}$ http://www.oaza.rs/sport/delije/prica , accessed: 24.04.2018. 
the regime to forge the results of parliamentary elections, which resulted in Milošević's resigning from power. The narrative of their action in the "first lines" of the rebellion rapidly rose to the level of myth. Only two months later, in December 2000, the leading oppositional media Radio B92 awarded the Red Star fans for their contribution to the "revolution" at the ceremony held at the Rex Cultural Centre in Belgrade. On this occasion, they were named "Heroes of Democracy" with the following elaboration: "Guys who defied the regime for ten years, clashed with the police while others slept in their beds. They are -'Delije'”. ${ }^{9}$

The political capital of football fans, gained already at the time of the dissolution of SFRY, was now revalorized and reinforced. They were no longer publically perceived as patriotic heroes but as the heroes of a democratic revolution. Nevertheless, the nature and character of the fan culture remained the same. In their perception, Milošević was not to be blamed for participating in the war, but for losing it. By accepting this subcultural group, the new "proEuropean" and "democratic" regime renewed the political credibility of football fans, still firmly based on the "title on patriotism". Football fans remained an important political factor after the so-called "democratic turn", and the stadiums were kept as one of the central political arenas in the first decade of the new millennium.

However, the formed alliance soon dissolved. The fall of Milošević's regime led to a thorough rearrangement of the existent political paradigm. The new government chose the road of the socalled "Euro-integrations", promoting the values of liberal democracy and market economy as the cornerstones of the desired EU accession. This agenda did not align with the ideological visions of fan groups, which still firmly held their position on the right pole of the political spectrum, and their enthusiasm for emitting political messages and cheers from the stadium stands had not diminished since the 1990s. Now, the articulation of their right wing-oriented ideology was manifested in slogans such are "Kosovo is Serbia",

9 According to: http://www.nspm.rs/komentar-dana/licemerje-ineprofesionalnost-medija-druge-srbije.html?alphabet=l 
sending a clear signal to the new regime that the fans were still the keepers of the "national question". The new millennium brought the new stadium folklore of chants filled with ethnic hatred and homophobia, such as "Ubij Hrvata" ["Kill the Croat"], "Ubij, zakolji, da Šiptar ne postoji" ["Kill, slaughter, so Shqiptar is gone"], "Nož, žica, Srebrenica" ["Knife, wire, Srebrenica"], or "Ubij pedera" ["Kill the faggot"]. The repertoire was accompanied by explicit support to the Bosnian Serb leaders Ratko Mladić and Radovan Karadžić, both of them indicted for war crimes.

The best example of the political influence the football fans had in Serbia during this period are the attempts at organizing a PRIDE parade in Belgrade, intended to promote the rights of the LGBT community (Đorđević 2015b). Already in the beginning of the 2000 s, the first attempts at organizing this event were made as a part of proclaiming "European values". However, Serbian political elites were not fully committed to supporting PRIDE, mainly as a way of avoiding a direct confrontation with the still powerful conservative political forces (Greenberg 2006; Mikuš 2011). Football fans, yet again, assumed the role of the "punching fist" in preventing the organization of PRIDE. Alongside performances at the stands ("Peder gradom neće šetati" ["Faggot will not walk the streets"], "Ubij pedera" ["Kill the faggot"] etc.) and graffiti on the city walls, they resorted to physical violence (Pavasovic Trost and Kovacevic 2013), successfully preventing PRIDE form taking place. As noted by Nielsen, in this way fan groups became "stronger than the state" (Nielsen 2013). The public perception of their actions was at least twofold. On the one hand, their actions of PRIDE prevention marked them as "violent hooligans" and "enemies of the state". But on the other hand, a certain part of the public perceived their actions as justified. The direct opposition to the promotion of the rights of the LGBT community, as part of the right-wing agenda in Serbia, reinforced the capital of the football fans within this segment of the political spectrum. They were imaged as "true patriots", as "our Serbian children" that were defending the "true", "traditional" values.

It is important to note that, regardless of the clearly political content that they are promoting and the influence they have, 
football fans determine themselves as explicitly apolitical. A valuable illustration of this is the interview of the leader of the Red Star fan group given for the magazine of the Serbian Orthodox Church, "Pravoslavlje":

"Older friends went to war when it all began, and we, at age eighteen, nineteen, took over the responsibility to lead the stands, and nationalism was left as inheritance. (...) We are not interested in politics; we all have our own private opinion on the elections. We managed to be apolitical because many attempted to win us over. In this we remained united; the Serb-hood is above everything else" (Pravoslavlje, 15.10.2008).

This statement clearly implies that their form of apolitical is deeply ideology-based, foremost through the discourse of nationalism (Đorđević and Pekić 2018). Additionally, the fact that this interview was published by the official newsletter of the Serbian Orthodox Church points to the importance of the Orthodox religion in the process of formulating the ideology in question. Many of the fans see themselves as deeply religious, and very often the stands are decorated with slogans with unquestionably Orthodox insignia. The importance and influence of this peculiar religion-fan union were clearly visible in the initiative of the Red Star fans to boycott all the games that take place on Easter Sunday. One of the fans' leaders explained this initiative in the following words: "The idea was started when we wanted to raise awareness of "Serbianness", which is very important in our stands. And we all know that Serb-hood does not obtain its intended importance without Orthodoxy“10.

Here the repetition of the pattern established already during the 1990s comes to the foreground. The pattern in which national identity is necessarily intertwined with the religious one (Malešević 2005; Malešević 2006; Čolović 2012) is clearly visible. Additionally,

10 Daily Newspaper "Telegraf", 9. 4. 2018. http://www.telegraf.rs /sport/navijaci/2949537-vodja-delija-vladimir-savija-objasnio-kako-jerodjena-ideja-da-se-bojkotuju-utakmice-za-veliku-subotu-i-uskrs-video, accessed: 10. 5. 2018. 
the integration of the Orthodox identity in the sum of the fan identity implies that "Serb-hood," inherited by football fans, similarly to the Serbian Orthodox Church represents a sort of supraideology, which is above the affairs of everyday ideology and politics. In this way, fans are (self-)declared as authentic keepers of the nation, as the main advocates and voice of the structure of the desired behavior designating the entire large, and highly diverse, group of people who feel or represent themselves as the Red Star fans.

The appropriation of the "watch dog" position basically functions as an "anti-political machine" (Ferguson 1990) by actively procuring ways to depoliticize space, diminishing the possibility of the appearance of any other alternative ideology, at the same time establishing "apolitical normality" which is, itself, highly political. This strategy can be referred to as the exploitation of a very specific condition of Serbian society following the fall of Milošević's regime in 2000 and onward. During the period of transition, Serbia made an attempt to implement the principles of market economy and liberal democracy, as all the other states in Eastern Europe. This process of the so-called "transition" (Mikuš 2013) is still ongoing, today transformed into a self-fulfilling prophecy, "revolving mostly around the following tropes: oscillation between liberalisation and authoritarianism; the complex relationship between the state, organized crime and the economy; corruption (...) regional cooperation or disputes, successes and failures in the EU accession process" (Štiks and Horvat 2015, 1). The overall disappointment with the outcome of such transition, especially in terms of the unfulfilled expectation of economic prosperity, resulted in "democratic policies understood as elitist, corrupt, morally suspect, and disempowering" (Greenberg 2010, 48). It led to the lack and deliberate rejection of active participation in the political process and "non-participation in politics as a 'rich set of moral, political and cultural engagements'" (Greenberg 2010, 43) became a legitimate political stand. The current-day fan ideology aligns with this political position, with members of fan groups refusing to take part in the political process they perceive as intrinsically rotten. On the other hand, the position they do assume is presented as a step-away from the corrupted politics, as a value set that is "above us all". They 
naturalize "Serb-hood" and "Orthodoxy" as above all ideological values. In doing so, they directly reject the proclaimed "European path" of Serbia and offer a moral position as an alternative - the moral position based on a totalizing narrative that leaves no room for a different interpretation.

The mutual dependence of football and the ideology of nationalism can be observed in the context and circumstances of the match between the national selections of Serbia and Albania that was to take place in Belgrade, in October 2014. In public, the match was predominantly shaded by the tensions of the unresolved issue of Kosovo, additionally boosted by the fact that most of the members of the Albanian selection were born there. Despite the high level of security, and the decision that the Albanian fans cannot attend the match, first incidents occurred soon after the game's beginning. Just before the end of the first half-time, in the atmosphere resembling more a political rally than a football game ${ }^{11}$, a drone carrying the flag of the so-called Great Albania flew over the stadium. The "explosive load" symbolically carried by the drone did not only have impact on the event at the stadium. Its effects were felt in a much larger radius. The eruption of hatred in the media and all over social networks caused a state of general mobilization against the Albanian arch-enemies, and it was not limited only to the highly biased rhetoric. In the following days, the patriotic "revengers" defended the "victimized Serb-hood" form the threats such as shops owned by Albanians (Đorđević 2015, 13-17).

The outburst of ethnic hatred, both verbal and actual, demonstrated once more the potential of the football stadium to mobilize for the defence of the "endangered nation". The naturalization and continuous reproduction of the "acceptable nationalism", embodied in both the promotion of the "ideal Serb" and in the constant locating of the "Other" (Croat, Albanian, EU, homosexual), transformed football fields across Serbia into tanks of the unquestionable nationalism that political elites can dive in when needed. Football fans are transformed into "professional patriots",

11 The cheering from the stands was mainly focused on the issue of Kosovo's status and on the proficient insulting of Albanians. 
ethno-political entrepreneurs as worded by Brubaker (Brubaker 2004,10 ). Due to their "title on patriotism", they can always offer their services to the "market of national goods", as they proved many times to be always ready to mobilize their forces and assume a role in the complex social and political process in the posttransitional Serbia. Their activities are closely related to the current interests of the political elites, aiming to keep the game colonized by politics as long as possible.

CONCLUDING REMARKS. The development of football in Serbia in the past eight decades has been conditioned by a transformation of the game itself but always heavily influenced and formed by broader societal and political contexts. Diverse dominant ideologies in the stated period determined the ways in which football has been perceived by both the political elites and "ordinary" fans. Following the end of WWII, its purpose was defined through building the "new socialist man". In this period, the primary focus was put on its educational role and its important position as a vehicle for rebuilding the state in the aftermath of WWII. The breach in the relations with USSR and the partial abandoning of the Soviet model led to the conceptualization of football, based on the ideals of selfmanagement, as the main pillar of Yugoslavia's socialist system. During the same period, and with the growing tension between SFRY and the Eastern Bloc, primarily with the USSR, the symbolic importance of sports as a resource in the political fight between ideologies was brought to the foreground. On the other hand, societal and economic contradictions of the Yugoslav system caused a continuous reproduction of crisis that also influenced football. This process culminated during the final years of the 1980s, with stadiums transformed into the symbolic loci of inter-ethnic clashes, merely announcing the events of the final dissolution of Yugoslavia.

Viewed from the symbolical point, the song of oath to Tito and his Yugoslavia sung at Poljud in Split in 1980, and the burning of the flag of that country on the same site only ten years later, illustrate the state's dissolution process. Additionally, these two events emphasize the importance of the football stadium in communicating powerful political messages, transmitted via 
television to the millions of citizens of the former SFRY. The ideology of nationalism that rose to prominence by the end of the 1980s became the main explanatory key for understanding the ongoing processes in football until today.

By comparing football in the time of socialism and postsocialism, as the period symbolically starting after the riots at Maksimir in Zagreb in May 1990, it can be concluded that the dissolution of Yugoslavia had a profound impact on the transformation of the game. Regardless of the fact that "socialist football" was heavily influenced by the state's ideology, it can be claimed that at that time football was mostly focused on the game itself. The main actors were the players, and the achieved results were the point around which the interests of both the public and the elites managing the sport were formulated. With the start of Yugoslavia's dissolution and with the triumph of the nationalist political elites, the focus was shifted from the game to a new group of actors - football fans. Their actions became more important than the achievements of football players, and their influence spread to a much broader arena of society. The situation didn't change much until today, and the fans are still the most important actors in football in Serbia. Their actions, closely related to the unresolved issue of Kosovo, the EU accession, or the PRIDE Parade, are publicly followed and perceived as socially and politically relevant.

This stated core change in the perception of the game at the same time illustrates the process and the results of the so-called transition. The sport is defined within the framework of Serbia as a state on the European semi-periphery (Hughson 2015; Đorđević 2012: 444). When considering the semi-periphery as a "system of structural societal dispositions which are intertwined with their location and territoriality that impact the core of their functioning" (Hughson 2015, 26), football in Serbia can be understood through the prism of the local market's structural economic dependency in relation to the states of the center, in our case located in Western Europe. In such a division of power on the football market, Serbian teams have the role of making "raw material" i.e., making players who will after a few matches leave for the richer countries, mainly in Western Europe. In such circumstances, the quality level of the 
game is rather low, and the main task of teams' management is the successful trade of young players, whose names the public do not even attempt to remember. Football in contemporary Serbia is left to live within the intertwining of neoliberal politics and the ideologies of nationalism, reproducing the status quo in which the main actors are moved from the field to the stands, and in which the game itself has almost no importance at all. The ideal of reaching the "British model" in which football games are attended by parents and their children, present in every discussion on the issues of Serbian football (Đorđević 2012), in its essence is a "cosmopolitan desire" (Simić 2014). The later presents an implicit political stand that in ideal parameters is the ultimate goal of the "civilized" society, to which all post-socialist countries, Serbia included, are aiming. Such a political position, either conscious or subconscious, that sets the states of the center as the ideal model (Spasić 2011, 278), is mainly used as the justification for the struggle endured along the way. However, in reality the functioning model of British football is structurally inapplicable on Serbian society. Here, the interplay in which the trade of half-products is presented as only a stage on the road to success and the achieving of "European relevance", and in reality is a structural demand and a necessity, makes the maintaining of this model possible. The cosmopolitan dream is placed on one side, while the nationalism of football fans flourishes on the other side of the political spectrum. They function as two sides of the same coin, therefore allowing the continuous reproduction of the state of "eternal transition".

\section{References}

Andjelić, Neven. 2014. "The Rise and Fall of Yugoslavia: Politics and Football in the Service of the Nation(s)." Südosteuropa 62 (2): 99-125.

Bourdieu, Pierre. 1986. "The Forms of Capital." In Handbook of Theory and Research for the Sociology of Education, ed. J. Richardson, 241-58. New York: Greenwood. 
Brentin, Dario. 2013. "'A lofty battle for the nation': the Social Roles of Sport in Tudjman's Croatia" Sport in Society: Cultures, Commerce, Media, Politics 16 (8): 993-1008.

Brentin, Dario and Dejan Zec. 2018. "From the Concept of the Communist 'New Man' to Nationalist Hooliganism: Research Perspectives on Sport in Socialist Yugoslavia." The International Journal of the History of Sport 34(9), 713-728.

Brubaker, Rogers. 1996. Nationalism Reframed: Nationhood and the National Question in the New Europe. Cambridge England New York: Cambridge University Press.

Brubaker, Rogers. 2004. Ethnicity without Groups. New York and London: Harvard University Press.

Čolović, Ivan. 2000. Politika simbola. Beograd: Biblioteka XX vek.

Čolović, Ivan. 2012. „Navijači - huligani i novi fašizam.” https://pescanik.net/navijaci-huligani-i-novi-fasizam/.

Dežulović, Boris. 2013. „Ostavite Hajduk na miru! Eno vam HAŠK i Građanski, pa s njima igrajte Pavelićevu ligu i vičite 'Ajmo, ustaše!'." Jutarnji list, 30.11.2013.

Đorđević, Ivan. 2012. "Twenty Years Later: The War Did (not) Begin at Maksimir. An Anthropological Analysis of the Media Narratives about a Never Ended Football Game." Glasnik Etnografskog Instituta SANU 60(2): 201-216.

Đorđević, Ivan. 2015. Antropolog među navijačima. Beograd: XX vek.

Đorđević, Ivan. 2015b. „Između ponosa i srama. Antropološka analiza narativa o 'Paradi ponosa' u savremenoj Srbiji." Glasnik Etnografskog instituta SANU 68 (2): 351-366.

Đorđević, Ivan. 2016. "The Role of Red Star Football Club in the Construction of Serbian National Identity." Traditiones 45 (1): 117-132.

Djordjević, Ivan i Relja Pekić. 2018. "Is there Space for the Left? Football Fans and Political Positioning in Serbia." Soccer \& Society, 19(3): 355-372. 
Ferguson, James. 1990. The Anti-politics Machine: 'Development', Depoliticization and Bureaucratic Power in Lesotho. Cambridge: Cambridge University Press.

Foer, Franklin. 2004. How Soccer Explains the World: an Unlikely Theory of Globalization. New York: Harper Collins.

Gagnon, V.P. 2004. The Myth of Ethnic War: Serbia and Croatia in the 1990s. Ithaca: Cornell University Press.

Glenny, Mischa. 1996. The Fall of Yugoslavia: The Third Balkan War. London: Penguin.

Goldblatt, David. 2008. The Ball is Round: a Global History of Football. $1^{\text {st }}$ Riverhead trade pbk. ed. New York: Riverhead Books.

Greenberg, Jessica. 2006. "Nationalism, Masculinity, and Multicultural Citizenship in Serbia." Nationalities Papers 34(3): 321-41.

Greenberg, Jessica. 2010. “'There's Nothing Anyone Can Do About It': Participation, Apathy and 'Successful' Democratic Transition in Postsocialist Serbia." Slavic Review 69(1): 4164.

Hoberman, John. 1993. "Sport and Ideology in the Post-communist Age." In The Changing Politics of Sport, ed. Allison Lincoln. Manchester: Manchester University Press.

Hobsbawm, Eric. 1992. Nations and Nationalism Since 1780: Programme, Myth, Reality. Cambridge: Cambridge University Press.

Hughson, Marina. 2015. "Otkrivanje očiglednog? Zašto je potrebna teorija poluperiferijalnosti?." u Kriminal i društvo Srbije, ur. Marina Hughson i Zoran Stevanović. Beograd: Institut za kriminološka i sociološka istraživanja.

Jansen, Stef. 2005. Antinacionalizam. Beograd: Biblioteka XX vek.

Kovačić, Davor. 2016. „Nogometni profesionalci u udruženom radu.” Časopis za suvremenu povijest 48 (1): 67-95. 
Malešević, Miroslava. 2005. "The Introduction od Religion to State Schools in Serbia and 'Orthodox(is)ing' the Identity of Serbian Youth." Ethnologia Balkanica. Journal for Southeast European Anthropology 9: 225-239.

Malešević Miroslava. 2006. „Pravoslavlje kao srž 'nacionalnog' bića postkomunističke Srbije." Svakodnevna kultura u postsocijalističkom periodu u Srbiji i Bugarskoj, ur. Zorica Divac, 99-121. Beograd: Etnografski institut SANU.

Mihailović, Srećko. 1997. „Rat je počeo 13. maja 1990.” U: Rat je počeo na Maksimiru, ur. Svetlana Slapšak i Hari Štajner, 77124. Beograd: Medija centar.

Mikuš, Marek. 2011. “'State Pride': Politics of LGBT Rights and Democratisation in 'European Serbia'“. East European Politics and Societies 25(4): 704-19.

Mikuš, Marek. 2013. "'European Serbia' and its 'Civil' Discontents: Beyond Liberal Narratives of Modernisation." Centre for Southeast European Studies Working Paper Series 7.

Mills, Richard. 2016. "Cold War Football: Soviet Defence and Yugoslav Attack following the Tito-Stalin Split of 1948", Europe - Asia Studies 68(10): 1737-41.

Mills, Richard 2009. "It All Ended in an Unsporting Way": Serbian Football and the Disintegration of Yugoslavia, 1989-2006." International Journal of the History of Sport 26 (9): 11871217.

Nielsen, Christian Axboe. 2010. "The Goalposts of Transition: Football as a Metaphor for Serbia's Long Journey to the Rule of Law." Nationalities Papers 38 (1), 87-103.

Nielsen, Christian Axboe. 2013. "Stronger than the State? Football Hooliganism, Political Extremism and the Gay Pride Parades in Serbia". Sport in Society 16(8): 1038-53.

Pavasovic Trost, Tamara, and Nikola Kovacevic 2013. "Football, Hooliganism and Nationalism: The Reaction to Serbia's Gay Parade in Reader Commentary Online." Sport in Society 16 (8): 1054-76. 
Riordan, James. 1999. "The impact of communism on sport." in The International Politics of Sport in the 20th century, eds. James Riordan and Arnd Kruger. London - New York: E \& FN Spon: Routledge.

Simić, Marina. 2014. Kosmopolitska čežnja: etnografija srpskog postsocijalizma. Beograd: Centar za Studije kulture Fakulteta političkih nauka i Čigoja.

Silber, Laura and Allan Little. 1996. The Death of Yugoslavia. London: Penguin.

Spasić, Ivana. 2012. Cosmopolitism as Discourse and Performance: A View from the Semiperiphery. Revija za sociologiju 41(3), 269-290.

Štiks Igor and Srećko Horvat. 2015. Welcome to the Desert of PostSocialism Radical Politics After Yugoslavia, London: Verso.

Vrcan, Srđan. 2003. Nogomet - politika - nasilje: ogledi iz sociologije nogometa. Zagreb: Naklada Jesenski i Turk.

Wilson, Jonathan. 2006. Behind the Curtain: Football in Eastern Europe: Travels in Eastern European Football. London: Orion.

Wood, Shay. 2013. "Football after Yugoslavia: Conflict, Reconciliation and the Regional Football League Debate." Sport in Society 16 (8), 1077-1090.

Zec, Dejan and Miloš Paunović. 2015. “Football's Positive Influence on Integration in Diverse Societies: The Case Study of Yugoslavia." Soccer \& Society 16 (2-3): 236-7. 

UDK $39+172.15$

DOI: $10.33876 / 978-542-110-238-0 / 179-206$

Ljiljana Gavrilović

\section{MMORPGS AND NATIONALISM ${ }^{1}$}

Communities which form within the worlds of digital games, especially MMORPGs are, in theory, a-national, because the basic premise of digital worlds is their limitlessness and the overcoming of boundaries that exist in the physical world. Gamers from different European countries are based on servers which are designated as international (English language European servers), these people speak different languages, but English is the default lingua franca.

Even though it is generally assumed that most guilds (communities) on these servers are international, there is also a strong tendency to form "national" guilds, comprised of gamers who speak the same native language. On the one hand, this is the consequence of the desire for better/easier understanding and communication within the community, but - as analyses of gamer behaviour on Chinese and Taiwanese servers show - also the assumption of shared cultural preferences, that serve to enhance the internal cohesion of the community. "National" guilds will often recruit members by publishing calls in their native language on public channels, which serves to deter anyone who doesn't speak the language in question. In these cases it is irrelevant where (in which country) the players are physically based, as the national borders are equated with the boundaries of language.

This paper will analyze recruiting messages published by "national" guilds, the behaviour/attitudes of the players and the discussions of ethnic/national issues on public channels and social networks in the MMORPG World of Warcraft. The data shows that, regardless of the assumed lack of borders in digital worlds, boundaries in online spaces are often set in accordance with ideas about nations

1 This manuscript was prepared as a part of the project no 177026 , "Cultural Heritage and Identity", funded by the Serbian Ministry of Education and Science. 
that players have in the physical world. On the other hand, there is the possibility that some gamers, through meeting and conversing with people from different countries and cultures in the digital world, correct and change the attitudes they formed in their physical surroundings, which then serves to facilitate their joining international communities, as well as diminishing ethnic barriers in the "real" world.

Key words: MMORPG, World of Warcraft, nationalism

"Alle MEnSChEn WERden BRÜDER...". At the start of this century, when digital massively multiplayer online (role-playing) games (MMOG/MMORPG) began their conquest of the world, ${ }^{2}$ there was an assumption that they are one of the routes of multiculturalism and transnationalism - a way to overcome boundaries between cultures, and with them, national borders. And truly, people from all over the world started meeting in the same (digital) spaces and spending a good chunk of their free time in constant interaction. As Lin and Sun put it:

"even though individuals may not be able to see the physical landscape of other worlds in MMOG interactive spaces, they can still sense other cultures and the potential for interacting with other people in those cultures. Population movement via telepresence and part-time residency in foreign spaces supports the idea that entering a MMOG world is not, as many believe, 'escaping from reality and entering virtual fantasy space'. Instead, it represaents 'entering new space' in which the influences of political and social

2 Massively multiplayer online role-playing game (MMORPG) is a genre of digital games in which a large number of players are simultaneously situated in the virtual world of the game, wherein each player gets into constant interactions (of cooperation or conflict) with other players. Meridian 59 (The 3DO Company, 1996) and The Realm Online (Sierra Online 1996) are considered as the earliest games of this kind, even though Ultima Online (Origin Systems, 1997) is mostly cited as the very first, as it really was the first fame to achieve thus unheard of popularity, with 200000 subscribers in 2000. 
power tied to physical location are reduced" (Lin and Sun 2011, 14).

In fact, games are, by rule of thumb, designed in a way which implies multiculturalism when it comes to attitudes and behaviour of the players:

"Applying this debate to the ascribed transnational
character of MMORPG's, it can be stated that games like
WoW ${ }^{3}$ fundamentally provide 'transnational' 'virtual
spaces' where culturally diverse people interact with
each other on a daily basis. Indicative of the 'default
multinationalism' which lies at the heart of WoW is the
elaborate Code of Conduct5, enforcing a certain amount
of 'civilized openness' amongst its members" (van Es
2009 , 4).

However, things are not that simple. Game designers as well as researchers are aware that:

"(in) the fantasy space of MMOGs, players bring their cultural habits and political views from their physical worlds. However, since real-world politics (including the power associated with business profits) do not fully control game worlds, they still retain meaning as spaces that support border crossing with little or no control, contacts between foreigners, and opportunities to experience different cultures" (Lin and Sun 2011, 14).

Nevertheless, everyone seems to have predicted that "cultural habits and political views" include, among other things, the view/understanding of the concept of nation and the relationship every player has to "their own", as well as other nations, and that these attitudes (as well as all other attitudes pertaining to other identity issues, which are considered in detail) influence everyday behaviour in the new setting. As early as 2006, Taylor pointed out

3 WoW: an acronym usually used to designate the game World of Warcraft, and which will be used further in the article. 
the necessity of studying the behaviour of players in online games which stems from their understanding of the concept of nation and the importance the feeling of belonging to a nation has for them in the physical/"real" world $\left(\mathrm{RL}^{4}\right)$. However, there has been little research of this kind up to now: aside from her article in which the key issues and questions are pointed out (Taylor 2006), there has been one, as of yet unpublished, MA thesis on the subject (van Es 2009), one article (Lin and Sun) which deals with Chinese and Taiwanese culture in digital space, and one, also unpublished, $\mathrm{PhD}$ thesis (Feng 2014) which considers the cultural conditioning of gamers' behaviour.

The lack of research on the ways in which different national feelings and concepts of nation influence gamers' behaviour stems from the fact that most research up to this point was conducted in English speaking environments. And, as the boundaries of language in digital worlds are mostly synonymous with borders of nation (in the best romanticist manner, but also for the simple reason of more successful communication), research in English speaking environments could hardly afford fertile ground for research on (different forms of) nationalism. Behaviour in games, at least in those in which it is possible, has, on occasion, been linked to issues of race - which is in keeping with the American anthropological and sociological tradition, and can be equated with questions of nationalism being asked in different historical/cultural/political contexts (Eriksen 1994/2010, 6-8) ${ }^{5}$. However, in these cases more attention is given to the design of virtual worlds, or rather, the shaping of games in accordance with racial and ethnic stereotypes:

4 The usual acronym for the "real"/physical world is RL - Real Life.

5 Even though Eriksen revised this opinion in the third edition of the book, considering that the concepts of race and ethnicity should be kept separate (Eriksen 1994/2010, 8-9), in the case of studying MMOG/MMORPGa, especially if the behaviour of the payers is being studied and not the design of the game, the equation between the two concepts can be kept because "nobody on the Internet knows that you're a dog, nor can they easily determine if you're black or white, male or female, gay or straight, or rich or poor. But they can immediately notice what language and dialect you are using" (Warschauer 2000, 156). 
"Stereotypes can be found in virtually any gameCuban drug dealers in Vice City; muscle-bound, violent rappers in Def Jam Vendetta; and Arab terrorists in every war game. Ready to Rumble, a boxing game, like GTA III, covers all bases, including racialized stereotypes of virtually, every community of color. The most popular character in the game is Afro Thunder, a gigantic, Afrowearing boxer who is more adept at talking trash than fighting. The game also features a Hawaiian sumo wrestler, who of course is fat, speaks poor English, and has slanty eyes; a heavy-accented Croatian immigrant; and a Mexican boxer named Angel (Raging) Riveria" (Leonard 2006, 84-85).

Or, as Monson precisely defined it: "the message is clear video and computer games rely heavily on racial and ethnic stereotyping of the most blatant kind (Monson 2012, 52)

Yet, there are sporadic studies of different player behaviour in line with differences in cultural models from which they enter into digital worlds (Nardi 2010, 176-196; Lin and Sun 2011; Feng 2014), but not studies (except partially, cf. Gavrilović 2012) of whether and to what extent the offline concepts of ethnicity and nation influence the everyday behaviour of players in a world which is not supposed to be nationally fragmented, nor studies of whether and in what way this behaviour changes over time.

... OR MAYBE NOT? In a globalized world -

“(...) race and ethnicity matter as much as ever as a source of oppression. On the other hand, as globalization and economic change blur traditional racial and ethnic boundaries, race and ethnicity increasingly intersect with other identity markers, related to religion, nationality, gender, and language in stimulating social struggle" (Warschauer 2000, 152).

The same goes for the Internet: even though it is a global network, the space within it is segmented in different ways, in 
accordance to the interests of the (potential) visitors, users and those who actively participate in creating content for online locations. One way of segmenting and framing is the use of language - locations, blogs and the use of social networks in languages of small nations and groups are, in fact, closed spaces in which intragroup communication takes place, communication in which only those who understand/speak the language of the group can take part. In a certain sense this can be considered as ghettoization, as the use of "small" languages disables dialogue/communication with members of other linguistic/cultural traditions, which effectively restricts the space for action of minority communities on the Internet. At the same time, this diminishes the possibility of representing one's culture worldwide, but facilitates communication between members who feel they belong to a group, regardless of their current location (cf. Warschauer 2000; Gavrilović 2008). The same process takes place in a large number of MMOGs as well.

Of course, this does not pertain to all online games: those that are based on cooperation, but not on everyday communication among players (such as Facebook games) are not susceptible to players grouping according to language, because the communication among players is minimal, and often nonexistent or not needed. On the other hand, teams in e-sports, which demand exceptional coordination in order to achieve results, are, by rule, comprised of members who share a native language; however, this has less to do with national preferences and more with the need for streamlining communication among members of the team. However, even among casual players (those who aren't members of tightly defined teams) of such games, one can often encounter complaints:

"Am I the only one who finds it hard to actually find people who can understand english? Either I'm playing with a team, with people from Spain or France, who can't speak english, or simply playing in a team where noone speaks. Which I find quite odd. Also for the EUNE servers, which is where I made a smurf, perhaps better luck there. But nope, only eastern European languages. Is it really that hard to find someone to communicate with?" (user: AA, 30. 01 2014, 
http://forums.euw.leagueoflegends.com/board/showt hread.php?t=1583455).

A more precise description of the problem is given by another player, speaking about the lack of success due to the language barrier:

\begin{abstract}
"We had 4 people speaking 4 different languages and because of that we couldn't talk about anything going on in the game. So many ult combo's went out the window, People just jumped the back line and no one could say anything because of the language barriers. I've played so many games where this has been a problem. People on my team not being bad teammates or trolling but just a team that is genuinely unable to work well together because they literally cannot communicate with one another effectively. I don't know if it's a problem on any of the other servers but in my experience it happens very very frequently on EU" (user: xD; 12. 03. 2017, https://www.reddit.com/r/ Overwatch/comments/5yy691/eu_servers_and_langua ge_barriers/?st=jecxankj\&sh=ce22625a).
\end{abstract}

Quick and effective communication between team members in this case isn't just a matter of personal preference among players, it is a prerequisite for effective teamwork and achieving the desired results, thus the complaints about the lack of a common language cannot only be interpreted as a desire for national/linguistic grouping, but should rather be attributed to the need for more efficient gameplay. ${ }^{6}$

6 This is line with the increasing tendency to rationalize every type of game as much as possible - to build the neoliberal concept of efficiency into gameplay in the way it has been built into behaviour in the physical world (Valkyrie 2017, 375-9), this is most evident in e-sports. 
WOW AND THE POLITICS OF MULTICULTURALISM/ MULTILINGUALISM7 ${ }^{7}$. There are, however, games which aren't just about competition, but represent worlds in which players spend time, make and achieve personal goals - in which an alternative life is lived. In these spaces, communication and the establishing of different social relations is one of the most important facets of the world. Social behaviour in these games is not just determined by the efficiency of achieving results, and is thus influenced by a variety of factors - foremost by identity practices shaped in the physical world, among which the concept of nation and national belonging ranks high.

The most famous and still the largest (in terms of duration as well as the number of registered and active players) MMORPG is World of Warcraft, ${ }^{8}$ which began it's - at this point 14-year-long existence in November of 2004 (in the US and Australia). It was the fourth game designed within the Warcraft universe ${ }^{9}$ set in the imaginary world of Azeroth, and the first game in the franchise that was completely conceived as an MMORPG. In 2005, WoW made it to Europe and Asia. In the first year alone, Azeroth was settled by more than 3.5 million players from every corner of the physical world. By 2008 the number of players reached 11.5 million, and settled at just over 11 million by mid-2011, it reached its peak at 12 million during 2010. The number of subscribers declined since then: with every

7 Data for analysis: the recruitment messages of "national" guilds, the behaviour/attitudes of players and debates about ethnic/national issues in public and private (guild) channels based on three EU servers, as well as on social networks where players gather. The data was collected between 2014 and 2018. All statements are cited verbatim, without correcting grammatical or orthographic errors.

8 Blizzard Entertainment, 2004.

${ }^{9}$ Real-time strategy games: Warcraft: Orcs \& Humans, 1994; Warcraft II: Tides of Darkness 1995 and the expansion Beyond the Dark Portal 1996; Warcraft III: Reign of Chaos 2002 and the expansion The Frozen Throne 2003. The possibility of multiplayer gaming was introduced in Warcraft III. 
new expansion 10 the population increases to over 10 million for a while, and then gradually declines to about 7 million players, with the largest drop taking place in mid-2015, when the number of denizens of Azeroth fell to about 5.6 million. ${ }^{11}$ After 2015, Blizzard Entertainment stopped publishing data on subscriber numbers, but using financial reports, it is estimated that the number of subscribers is now stable at around 5 million. ${ }^{12}$

This huge number of players is not situated in the same space: the world of Azeroth is divided into 3 large zones ${ }^{13}$, within in which it is further divided into servers (realms), which constitute the main space for communication and grouping among players. ${ }^{14}$ The basic unit of social organizing among players is the guild. Guilds don't have a pre-defined internal structure or number of members, so internal relations in these communities can vary: there are guilds that are tightly organized with a hierarchical structure, but there are also those that favor democratic decision making; in larger

10 In the meantime, the game received five expansions (meaning an expansion of the story, and withit, the world): The Burning Crusade 2007, Wrath of the Lich King 2008, Cataclysm 2010, Mists of Pandaria 2012 and Warlords of Draenor 2014. In July 2015 a new expansion titled Legion was announced.

11 Of course, these numbers only include gamers who pay for their subscriptions and play on official servers, and not those who play on pirate servers and are left out of the official statistics. The source of the data about the number of players, up until the second quarter of 2015 can be found here: http://www.statista.com/statistics/276601/number-of-world-of-warcraftsubscribers-by-quarter/.

12 These assessments are from January 2018, but an increase in player numbers is expected in the second half of the year, because a new expansion (Battle for Azerot) was announced for August 14th 2018.

13 US (which encompasses North and South America, Oceania and Australia), Asia and Europe.

14 Over the last two expansions the possibility of "jumping" from server to server was introduced when doing certain tasks for which the game groups players automatically, rather than let players organize themselves (LFR, DF, LFG). This doesn't change the scheme of organization, althrough it can sometimes lead to communication problems which are absent from selforganized groups. 
guilds it is easier to organize groups for specific activities, while smaller guilds tend to facilitate closer interpersonal relationships etc.

Communication within the game can be public or private. Public communication takes place on two channels (General and Trade), and it is exclusively written, while private communication takes place within guilds and in private conversations between players and can be written (chat) or audio.

Even with a significantly smaller number of subscribers than at the height of its popularity, WoW is still the game/digital world with the largest stable population (in comparison to other MMORPGs). This, as well as its long duration, makes it a fertile ground for studying different player behaviour and their interactions, including behaviour and attitudes pertaining to players' understanding of the concept of nation in the physical world.

WHAT THIS LOOKS LIKE IN PRACTICE? T. L. Taylor cites a conversation among players (outside any channel) which she witnessed in 2005 , and which prompted her to consider national approaches to WoW:

"Player 1: english in general please

P2: this is not general!

P1: it doesn't matter, english in all channels apart from tells

P3 [part of the Danish-speaking group]: err nope dude

$\mathrm{P} 1$ : no, english en general chats is the rule

P1: in*

P2: say has no rules for that

P4 [another member of the group]: well ... ah ah ah ... you can't touch me

P1: english in all chat apart from /w [whisper, private messages from one player to another]

P1: its in the server rules

P1: go read if you don't believe me" (Taylor 2006, 320). 
Taylor further states that in many cases she heard that: "[p]layers regularly say that Blizzard prohibits anything other than English in nonprivate speech, often directing people (as in the previous incident) to 'go read the rules'” (Ibid.).

And that they even threaten to report those who do not obey this rule, even though, in the written rules there is no mention of this - on the contrary, it is recommended that players communicate in the language that the greatest number of them understand, and it is clearly stated that the use of other languages (i.e. those that aren't the default language of the game and its tech support) will not be sanctioned.

So, in 2005, among a number of players there was still the belief that the "official" language of the realm was the mandatory language of communication within it, even though those who were in Azeroth from the very beginning decidedly state that this was never the case. Rather, the players used their native languages, even in public communication, and the easier communication in these languages caused the grouping of players on certain servers:

"Never heard of that. I had to leave my first realm back in classic (on release) due to people speaking mainly Spanish and being aggressive to anyone speaking English (I'm Spanish myself, but it meant people were not... kind towards you if you tried using English), and the first PvP realm I played in was basically taken over by Spaniards. Also during classic" (user: N; 30. 04. 2015, https://eu.battle.net/forums/en/wow/topic/ 14 381090012?page $=1$ ).

Many years later (in 2016), in one of the public channels (Trade chat,on another server), a conversation on the same topic took place, but with significantly different answers:

"R.: Hey quick question, whats the primary language of this realm?

M.: English?

S.: English

S2.: Dick

S3: idk look at chat :L 

E.: Engrish
G.: american
H.: dansk
I.: russian
R.: ancient hebrew
M.: Canadian
G2.: clue is in the realm list
P.: klingon
A.: Romana
H2.: hungary
F.: Bullshit mostly
R2.: Mandalorian
I.: latin
Н.: І. : откуда вы
B.: ancient egyptian
N.: Mongolia
R.: wha the realm list says isnt always true
S4.: Norway"

The flow of the conversation shows that the issue of Englishas-official-language isn't taken seriously by anyone anymore, because, in the meantime, the policy that allows all languages became abundantly clear. The so-called "official language of the realm" pertains only to the language in which the game and the tech support for it is delivered to users. However, the fact that the question was even asked shows that there were still players (probably new ones) who weren't familiar with the multilingual policy.

Blizzard never attempted to prescribe any language to its users. And this doesn't only pertain to European servers, but also those in the US/North America:

“There are no 'english speaking' realms. There are no 'spanish speaking' realms. ... All NA servers are in the same queues. There is no rule saying that you have to speak english to play the game" (user: S; 4. 01. 2012. https://us.battle.net/forums/en/wow/topic/3867056 866), 
Over the years, asking questions about English as the ultimate language of communication came to cause near-universal condemnation:

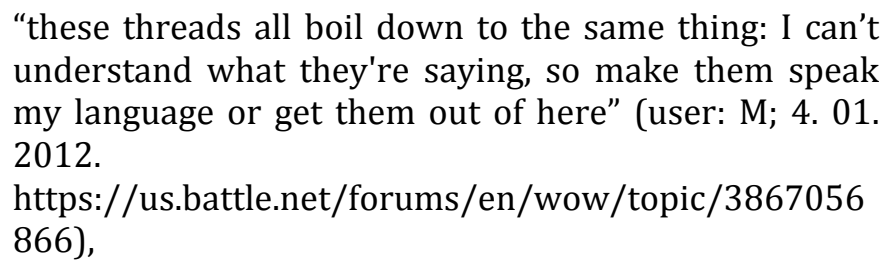

"these threads all boil down to the same thing: I can't understand what they're saying, so make them speak my language or get them out of here" (user: M; 4. 01 . 2012.

https://us.battle.net/forums/en/wow/topic/3867056 866),

And those who would ask them were often designated as "racists", or at least as "insensitive" toward players who speak languages other than English. This, however, doesn't stop players from complaining about the language barrier, especially in cases when they are forced to use tools for grouping (LFR, DF), when the server groups players for certain tasks and the group ends up with more people who (maybe) don't speak English:

"I would like a server that is really active and not only some random languages in the chat I don't know" (user

JH; 1. 04 2018, https://www.facebook.com/groups/ OriginalWoWeu/?fref=nf).

This change in understanding of the concept of "official" language as the only language of public communication is a process which, as we can see, has been taking place since the very beginning of the game and all new players are consistently taught tolerance and understanding that all languages are equal.

The preferred multilingualism becomes most prominent on New Year's Eve, when players on European servers start wishing a happy new year to everyone on the public Trade channel, using most European and even some non-European languages to do so. This is the only moment when no one complains about the use of local languages on one of the official channels, on the contrary - the multinational spirit of European servers shines through.

EACH TO THEIR OWN. Yet, the very concept and game design are, at least in part, in opposition to the preferred (and theoretically 
assumed) multilingualism/multinationalism of the game. From the very beginning, on European servers the game was offered in multiple languages (English, Spanish, German, French), and later added Russian (2008), Portuguese (2011) and Italian (2012), so the grouping of players in line with native language is clear and expected. On US servers, the game was first offered only in English, but a version in Spanish was quickly added, as well as a version in Portuguese. Versions of the game in different languages are logical from the standpoint of expanding the player base to those who don't speak English, but they also cause the closing off of players into the confines of "their own" language, thus diminishing the possibility of interactions between people from different cultural/linguistic zones.

Regardless of game design, speakers of languages that don't have a specialized version of the game tend to group on certain servers, which means that their languages frequently pop up in public communication:

"Europe is obviously a continent of many, many languages. Unofficial language communities do gravitate towards particular servers, there's the Afrikaans communities on Kazzak and Sylvanas, the Arabic and Dutch communities on Kazzak, the Finnish communities on Stormreaver \& Tarren Mill, the Russian community on Silvermoon (they literally hate playing with their own people sometimes), Swedish community on Frostmane and so on..." (user: LC; 1. 04. 2018, https://www.facebook.com/groups/OriginalWo Weu/?fref=nf).

Which players often view as "natural" grouping in national frameworks:

“ $(\mathrm{t})$ here's many 'unofficial' language $\mathrm{X}$ servers, like for example greek and genjuros, Hungarian on Ragnaros, etc. but there's many English speakers on all of these that I've ever been to, there just tends to be places where some nationalities congregate when they want to play with their own kind" (user: JS; 1. 04. 2018, 
https://www.facebook.com/groups/OriginalWoWeu/? fref=nf).

This is obviously an idea which was imported from the physical into the digital world. In line with this idea about national grouping as completely "normal", new players are often advised to do some research before entering the world in order to determine on which server the speakers of their language (even if it's English) congregate, in order to ease themselves into the game.

Another way of grouping according to language is by forming guilds. ${ }^{15}$ In early 2018, there were 19104 guilds which had at least some results in the final segment of the last expansion 16 (https://www.wowprogress.com, 4. 3. 2018), and their layout according o servers divided by language was:

\begin{tabular}{|c|c|c|c|}
\hline $\begin{array}{c}\text { Server } \\
\text { language }\end{array}$ & $\begin{array}{c}\text { Number of } \\
\text { guilds }\end{array}$ & $\begin{array}{c}\text { Server } \\
\text { language }\end{array}$ & $\begin{array}{c}\text { Number of } \\
\text { guilds }\end{array}$ \\
\hline English & 7511 & German & 5982 \\
\hline French & 2586 & Russian & 2078 \\
\hline Spanish & 679 & Italian & 248 \\
\hline Portuguese & 32 & & \\
\hline
\end{tabular}

${ }^{15}$ Language is by no means the only criterion for joining a specific guild: an important criterion is the player's relationship to the game (casual/hardcore), age (there are guilds whose members are all middle-aged or older, and there are many guilds that don't accept players under 18 years of age), the size of the guild and others.

16 This means that they killed at least one "boss" from the final raid, playing at the easiest level of difficulty (Normal, which is followed by Heroic and Epic). As only "big" guilds can organize teams for completing specific tasks, they are the only ones considered in the analysis, because they are the only ones that appear on the scoreboards. Of course, there is a great number of guilds that don't want to raid or don't have enough (interested) members, and are more focused on the social or economic aspects of the game. Their number varies and it's practically impossible to count them, especially while taking into account the languages they speak. Thus data from wowpeogress.com, even though incomplete remains the most reliable. 
English servers are also considered international because it is assumed that speakers of German, French or Russian will congregate on "their own servers" while all others will mostly go to English servers as English is taught in schools in virtually every European country, making it a lingua franca. Thus, English servers also tend to house a great number of guilds which are marked as language specific. These are mostly "smaller" languages that don't have specialized servers, even though there are those who choose to play on an English/international server, but keep the intra-group communication in another language:

\begin{tabular}{|l|r|l|r|l|r|}
\hline Arabic 17 & 11 & Bulgarian & 29 & Chinese & 6 \\
\hline Croatian & 19 & Czech & 137 & Danish & 102 \\
\hline Estonian & 5 & Finnish & 113 & Greek & 39 \\
\hline Hebrew & 6 & Hungarian & 123 & Iranian & 11 \\
\hline Korean & 2 & Latvian & 4 & Lithuanian & 4 \\
\hline Norwegian & 69 & Polish & 187 & Portuguese 18 & 12 \\
\hline Romanian & 24 & Slovakian & 1 & Slovenian & 2 \\
\hline Swedish & 244 & Turkish & 89 & Italian & 1 \\
\hline \multicolumn{5}{|c|}{ Total: 25 languages; 1240 guilds } \\
\hline
\end{tabular}

This means that there were only 6271 Englishspeaking/international guilds, which is just under a third of the total number of guilds on all European servers. This, in turn, means that a large number of European players chose ${ }^{19}$ to play in communities the primary language of which isn't English.

17 Aside from the 12 on English speaking servers there i another Arabic guild on a Spanish server.

18 Out of these 13, 11 are based on a server connected to the Portuguese, so they can easly change the language of public communication.

19 It is impossible to determine this number precisely: data on the number of players on each server isn't available - only the number of characters, and as one player can have 1-11 characters per server, and up to 50 per user account, there is no way to determine their real number. 
The strategies of organizing into national guilds vary. Recruitment messages (on one of the public channels or in Guild Finder) in different European languages are obviously targeted only at the speakers of those languages (who do not have to be members of the specific nation the language of which is used, but these cases are rare), and in these cases the linguistic exclusivity is complete:

\section{"Guilda *** - 11/11 HC si 1/11M recruteaza romani pt Antorus Mitic raid/social. Pst me pt detalii." \\ "Hrvatski guild svi lvl ilvl clase su DOBRO DOŠLE !!!!!"}

There are, however, messages in English which underline the exclusive national criteria for taking on new members (e.g. "ONLY POLISH"), and in these cases it remains unclear why the recruitment message is in English, if only members belonging to one nation are expected to apply.

Some of the national guilds are so exclusive, that they are willing to shut down due to lack of membership rather than lower their criteria and accept players who aren't hardcore, or internationalize. This happened to the Paragon guild which was considered one of the most successful on a global level for years. Seita, the longstanding Guild Mater explained the decision to shut down the guild in this way:
"We have decided to stop raiding which obviously means we will not be a part of the world first race in Legion. In the end it came between going international, playing with suboptimal Finnish roster or quitting. For a while I was seriously considering going the international route, but in the end decided it was not worth the trouble for me" (25. 02. 2016, https://www.paragon.fi/node/1122.html).

The other, completely opposite option is to change the character of the guild over time, as shown by the case of the ExYu guild, which was founded with the goal of gathering players from the territories of the Former Yugoslavia, but was, in 2016, completely international, with basic communication taking place in English, while the majority of the members (aside from the Guild 
Master, a woman from Former Yugoslavia) didn't even know why the guild bore the name it did.

There are guilds that seek membership among players who speak closely related languages - in these cases nationality isn't the deciding criteria, but rather the possibility of mutual understanding. Even though different yet related languages are spoken, it can be assumed that the desirable members are somehow "less foreign" (Eriksen 1994/2010, 137) than all others who speak different languages and, possibly, come from vastly different cultures. This mostly pertains to Scandinavian (the Danish, Norwegians and Swedes), Belgian-Dutch, Czech-Slovakian and Balkan guilds ("We are Duch/Belgium gaming clan, playing WOW with friends. We recruit Duch/Belgium people only - 18+, no exeptions"), while in other cases guilds decide to extend their membership to those who don't speak their native language, even though they point out certain preferences ("We prefer players from CZECH or SLOVAKIA but others are welcome as well"; "Norvegian guild but evry one is wellcome"). Aside from this, there are guilds that are conceived as international from the beginning, but with an accent on specific nations/languages and the idea that all of these languages be used equally in internal communication ("Looking for English/Russian/Lithuanian speaking people...”).

There are those guilds whose basic recruitment messages are in English, but they re repeated in the preferred language of internal communication ("Balkan: Prvi balkanski guild na CoA serveru; Midhnight Mafia: Pozdrav svima novi guild traze se svi balkanci da pokrenemo ovaj guild"), which obviously means they are counting on international membership, even though players speaking a specific language are preferred. In these cases the communication within the community is, by rule, bilingual: it is considered good manners to use English when members who don't speak the specific preferred language are present.

National guild names, such as "Proud to be Danish", "Danish Vikings", "Polania", "Magyar Szövetésg", "Croatian Knights", "Polish Winged Hussars", "OnlyTurko", "Türk Guildi", clearly point to the intention to organize on a national basis when founding a guild, but this doesn't mean (as evidenced by the example of the ExYu guild) 
that this intention is achieved in practice. Besides, there are names which point to the regional character of a guild ("Balkan") and the expectation that its members come from the designated region. ${ }^{20}$ Thus we see that the practice of naming guilds doesn't necessarily correspond to their national/international character, as the spectrum reaches from localized guild names even though they are open to all players, across the completely opposite practice of naming a guild in English, yet insisting on members belonging to a certain nationality, to complete localization, when both the name and the recruitment message are in a specific language, unknown to most of the gaming population.

There is a special case comprised of guilds in languages that are considered a "minority" everywhere. This is exemplified by the Japanese guild $\mathrm{n}$ the European Russian server or Japanese guilds on US servers: the lack of a localized version of the game directed Japanese players to servers outside their zone, where, despite the language barrier, they feel better than they would in "their own" zone (where the language barrier also exists), and in which there are apparent national tensions in the physical world. The same goes for "national" guilds that lack a national space in the physical world (that lack a nation-state), but successfully organize in a digital framework (the example of which is a Kurdish guild on one of the European servers).

From all of the above we can see that there are numerous strategies of including nationality into organizing communities in digital game spaces. These can go from complete disregard for nationality while embracing the official language of the server as the basic language of internal communication, to complete national exclusivity.

20 Guilds that have the word Balkan in their name or recruitment message are usually looking for members from the Former Yugoslavia, not Greeks, Bulgarians or Romanians, because the language of the message/communication is usually one of the languages derived from SerboCroatian. 
IF THERE ARE NO CHINESE, I CAN AT LEAST DISLIKE/HATE THE RUSSIANS. WoW, at least according to the literature lacks the prejudice which is usual in other games: the Chinese aren't mentioned as gold-farmers, ${ }^{21}$ for the simple reason that the Chinese play their own localized version of the game on their own servers in the Asian zone. ${ }^{22}$ It was the very size of the WoW universe that facilitated the division into zones and disabled the birth of this specific kind of prejudice, because players from the European zone never come into contact with players from China. But, the division into zones, or rather the restricting of the population to players from European countries, enabled the birth of prejudice toward certain European peoples on European servers, prejudice which was mostly imported from the physical world. Mostly, this is generalized at the level of language:

“D: germans are cancerous in pugs (Pick Up Groups)

V: I live in germany and yes, germans are unfriendly" (Guild chat, 6. 09. 2016)

This excerpt clearly shows the connection being established between the behaviour of players from German-speaking areas (including people from Austria and Switzerland) with the impression/prejudice which exists about Germans in the physical world, which is evident in this example:

21 This is the most famous national/cultural prejudice among gamers in general ("They're all Chinese and they all farm. Case... freaking... closed", Yee 2006), even though turning digital goods and services into real money occurs in all Third World countries (Heeks 2008). It wasn't imported from the physical world, it exists only within the confines of the digital worlds of various games.

22 Coming into contact with Chinese or goldfarmers from another country is only possible through buying WoW currency or other goods/services from sources outside the game specializing in such transactions for various games. Even through Blizzard Entertainment forbids both goldfarming and using these services, on almost every server there are messages advertizing services offered outside the game, but they usually aren't reacted to publicly, and even if they are, they aren't linked to Chinese players. 
"A: do germans get more mean when their ilvl increases?

D: no they get dumber

A: dumber

A: true D:

S: They'll get even the dumbest

I: I worked $10+$ years in Germany, they are very nice people

A: I live in munich

A: they're considered nicer among germans, but hah!" (Guild chat, 07. 09. 2016).

Stereotypes about members of specific nations are most frequently displayed in private communication within communities, especially when there are no members of these nations within these groups (in the guild in whose chat Germans were negatively characterized, there are no Germans, even though the guild is international), but there are national prejudices which are displayed on public channels, such as the prejudice about the poverty of Romanians:

"M: Any romanian guilds?

R: romanians cant afford wow" (General, 24. 09 2017).

A prejudice, which, even though based on the objectively bad economic status of Romania in comparison to some other members of the EU, is still malicious. ${ }^{23}$ In general, negative attitudes on

${ }^{23}$ A good example of rating players of different nationalities appears in a comment about another game (Counter-Strike: Global Offensive). From it, it's obvious that practically everyone (except members of the nation the author of the comment belongs to), are negatively characterized: "well after years of online-gaming I somehow feel like all polish gamers only know one word, don't know any English and are somewhere between 0 and 13 years old. French gamers also seem to know only their own langauge but at least it has more than one word. German gamers consist of people under 16 and people over 35 and speak all kind of different dialects except for regular German you hear on tv. But at least they know some English. Sometimes. Ah, also there are Turkish gamers - those don't know any language at all, but have names like xXIstanbulStyle63Xx (c_n, 29 Aug 2015, http://9gag.com/gag/aPGx6RB/how- 
members of different nations aren't a regular occurrence, especially in public communication, but that is probably a consequence of the strict behaviour guidelines, which prohibit insults based on identity, and which, if reported, could result in a long-term ban.

This, however, does not stop players from venting their negative thoughts and attitudes eslewhere. Foremost in different locations where WoW players congregate (Battle.net, ${ }^{24}$ MMOChampion, reddit etc.). Judging by these locations, on European servers, the position of the usually disliked Chinese is taken up by the Russians. Even though the anti-Russian sentiment isn't visible in the game itself, alternative locations are chock-full of complaints about Russian players, going from the fact that Russian names are unreadable because they're in Cyrillic. ${ }^{25}$

“Every battleground it's Russians. What really buggers me is that I can't even pronounce their name. If I say to my teammates in chat kill that healer gzebdshalzkss nobody has a clue who you are talking about because to us their names are literally unreadable. Wow should translate their names in latin letters for us. We are not russians we can't read russian so don't give us russian letters for gods sake how can I lead my team when I can't even pronounce their names" (Voïdelf, 14. 01. 2018, https://eu.battle.net/forums/en/wow/topic/17 617701892)

russian-cs-go-players-see-the-world-when-i-tell-russians-that-i-m-fromfinland)

24 Blizzard precisely defines the violation of rules on race and ethnicity as: "both clear and masked language and/or links to websites containing such language or images which: Promote racial/ethnic hatred; Are recognized as a racial/ethnic slur; Allude to a symbol of racial/ethnic hatred", and it pertains to nationality as well: "language and/or links to websites containing such language or images which: Promote national hatred; Are recognized as national slurs; Allude to symbols of national hatred" (eu.battle.net/en/community).

25 Players who complain about not being able to read Cyrillic names are from areas which lack the need to install a Cyrillic keyboard as part of their operating system. Installing Cyrillic support for Windows solves this problem. 
To the fact that Russians converse in Russian/Cyrillic amongst themselves when they're in a group with players from other countries:

"The only problem i see, is the language barrier
because of the cyrillic alphabet." (sunxsera, 17. 10.
2015, https://www.mmo-champion.com/threads/ 188
0917-What-s-the-problem-with-Russians/page2).

As if a conversation in a foreign language would be any more understandable if it was written in the Latin alphabet, to the fact that in the PVP (Player versus Player) segment of the game the Russians enter the battleground with groups that were organized in advance (and, of course, win), that their strategies of gameplay are unacceptable.

"Seriously, it was way better when they had their place to do whatever, far away from our servers. They ruin every BG with endless graveyard farmings and pointless defends in $\mathrm{AV}$ and dumb holding the flags forever and all that !@\#\$. They are doing this $\%^{\wedge} \_*$ just to piss people off, man i want them gone from EU servers, I know its never going to happen but this is !@\#\$ (Talldarin, 23. $09 . \quad 2016$, https://eu battle.net/forums/en/wow/topic/17613462055?page =1)

And even that they generally cheat in the game and that this is a well-known fact:

"Russia and balkan countries are known for their corruption and cheating in every spectrum of life. It is not that far grasped to say it is the same in their gaming culture." (Hanablossom, 17. 10. 2015, https:// www.mmo-champion.com/threads/1880917-What-sthe-problem-with-Russians/page2).

All the complaints about the Russians are best summed up in the statement: "M: the problem with Russians is that they are Russian" (Guild chat, 01.12. 2017). 
On one hand, this is the consequence of a lack of understanding of the Russian language and culture, which positions the Russians on the far end of the spectrum of otherness - they are "more foreign" than members of other European nations, which is recognized by many who object to the negative perception of Russian players:

"This is another thing that annoys me about the EU WoW community. Every time they lose to Russian players, they specifically rant about overall and suggest/ask for Russians to be removed from our regional servers. When it's a team of Spanish, do they ask for Spanish players to be removed from our servers?

Do they ask for other Italian, French, German, Swedish, British, Danish etc etc to be removed? no - it's because they can read their names and server names but they can't read the Russian's players names. So basically, these people are just xenophobes... even if that's on a minor level or major level" (Inspired, 25. 09. 2016, https://eu.battle.net/forums/en/wow/topic/1761346 2055).

While, on the other hand it is a consequence of geopolitical relations (Vice 2017) and the generally negative image of Russia in Western media (Kabel 2017, 34), that, in the physical world shapes the attitudes and opinions of the players. The animosity toward Russians is the best example of importing offline attitudes about specific nations into digital space, in which there is no reason for them.

AND YET IT MOVES. Despite the idea that MMORPGs afford players a multicultural space in which boundaries between languages, cultures and nations have no meaning, the presented data shows that players import their offline nationalism into this space to a large extent. While nationalism is not immanent to the concept of the game, it is meaningful for the behaviour of the players as it is based on their personal RL experiences and worldviews. Yet, the relationship toward nation ("one's own", 
"others" or different variants in-between) in the space of games is restricted to a choice of who one will be in community with and to the occasional display of attitudes in public, or in the private space of a guild, and to a far lesser extent to everyday behaviour and achieving of goals within the game. The grouping of players from different cultural/linguistic zones, although occasionally negatively commented on, is never the cause for giving up a common goal. There have been no recoded cases of anyone leaving a group because there were too many Russians or Germans in it, and thus giving up their goal or postponing its completion, despite the limited possibilities of communication. This points to a real disregard for national borders, as much as they may be declaratively maintained. As shown by the example of players from Serbia (Gavrilović 2012), the process of overcoming borders is slow and hard, all the more slow the harder the attitudes, beliefs and prejudices imported from the physical world. And this obviously doesn't pertain only to Serbia, but to the whole European and global player population.

Still, a large number of players publicly express attitudes which are in opposition to maintaining national borders in digital space. Some of them think that entering digital space enabled them to be in contact with people they wouldn't have otherwise been able to meet, and that this experience positively impacted their lives in the physical world and enabled them to attain knowledge which they would have had a hard time gaining in the physical world:

"Ive actually become better at speaking and writing english due to playing WoW on EU servers. And I love that Im in a guild with people all over Europe. Im danish but would never chose a danish only speaking guild or if we had servers only for danes (like the french and the germans have)" (M. B, 1. 04. 2018,

https://www.facebook.com/groups/OriginalWoWeu/).

While others are firm believers in the multicultural potential of the game: 
"My general philosophy is, that while playing WOW, we are either of Horde, Alliance or those that dont care about either but just do stuff they like. Nationality belongs outside the game world." (Dezri, 24. 09. 2016, https://eu.battle.net/forums/en/wow/topic/1761346 2055?page $=2$ )

"nationalism should have nothing to do with wow.join a debating club for such subjects if they really concern you" (Martikk, 24- 09. 2016, https://eu.battle.net /forums/en/wow/topic/17613462055?page=3)

They are in complete alignment with the assumptions that have been around since the inception of digital worlds, even if they aren't being achieved in practice at the expected pace. Yet, as within digital worlds nationalism doesn't reflect on the real behaviour of the players, it can be assumed that the value system by which some nations are more worthy than others will change toward the expected/desired understanding that " $\mathrm{O}$ : Nationalism (...) gratest sickness of 20th century, in the end we are all people that share same values" (Guild chat, 07. 04. 2017).

\section{References}

Van Es, Nicky. 2009. "For the Horde and the Nation?." A Study of 'National Play' in World of Warcraft. Master Thesis - Research Master Sociology of Culture, Media and the Arts. Erasmus University Rotterdam; https://thesis.eur.nl/pub/13431/Es, \%20van\%20N..pdf

Eriksen, Tomas. 1994/2010. Ethnicity and Nationalism. Anthropological Perspectives. Third Edition. London, New York: Pluto Press.

Feng, Jihan. 2014. From Role Play to Behavior: How Cultural Background Influences Western and Eastern MMOG Players. In World of Warcraft. Master Thesis, School of Literature, Media, and Communication, Georgia Institute of Technology.

Gavrilović, Ljiljana. 2008. "Serbian Minority/Refugees on Internet: In the Midst of Denial and Acceptance of the Reality." In 
Internationalizing Internet Studies. Beyond Anglophone Paradigms, eds.Gerard Goggin and Mark McLelland, 145-160. London: Routledge.

Gavrilović, Ljiljana. 2012. "MMORPG: An Entrance into the World without Borders." Ethnologia Balkanica 16 (Southeast European (Post)Modernities - Part 2: Changing Forms of Identity, Religiosity, Law and Labour): 353-369.

Heeks, Richard. 2008. "Current Analysis and Future Research Agenda on 'Gold Farming': Real-World Production in Developing Countries for the Virtual Economies of Online Games." Development Informatics, Working Paper Series 32.

http://hummedia.manchester.ac.uk/institutes/gdi/publicat ions/workingpapers/di/di_wp32.pdf

Kabel, Lars. 2017. The Coverage of Russia by the Danish Media. On media created images and their consequences. Aarhus: Danish School of Media and Journalism.

Leonard, David. (2006). “Not a hater, just keepin' IT real: The importance of race-and genderbased game studies." Games and Culture 1 (1): 83-88.

Lin, Holin, Chuen Tsai Sun. 2011. "A Chinese Cyber Diaspora: Contact and Identity Negotiation on Taiwanese WoW Servers." Proceedings of DiGRA 2011 Conference: Think Design Play. DiGRA / Utrecht School of the Arts, Volume 6.

Monson, Melissa. 2012. "Race-Based Fantasy Realm: Essentialism in the World of Warcraft." Games and Culture 7 (1): 48-71.

Taylor, T. L. 2006. "Does WoW Change Everything? How a PvP Server, Multinational Player Base, and Surveillance Mod Scene Caused Me Pause." Games and Culture 1 (4): 318-337.

Tsygankov, Andrei. 2016. "The Dark Double: the American Media perception of Russia as a Neo-Soviet Autocracy, 2008-2014." Politics 37(1): 19-35.

Valkyrie, Zek. 2017. Game Worlds Get Real. How Who We Are Online Became Who We Are Offline. Santa Barbara, Denver: Praeger - ABC Clio. 
Vice, Margaret. 2017. "Publics Worldwide Unfavorable toward Putin, Russia But Few See Russian Power and Influence as a Major Threat." Pew Research Center, http:// assets.pewresearch.org/wp-content/uploads/sites/2/2017/ 08/16105548/Pew-Research-Center_2017.08.16_Views-ofRussia-Report.pdf

Warschauer, Mark. 2000. "Language, Identity, and the Internet." In Race in Cyberspace, eds. Beth Kolko, Lisa Nakamura and Gilbert Rodman, 151-170. Routledge.

Yee, Nicholas. 2006. The Daedalus Project Vol. 4-1. http://www.nickyee.com/daedalus/archives/pdf/4-1.pdf. 


\section{Some Basic Factors of Pilgrimage in CONTEMPORARY SERBIA ${ }^{1}$}

Pilgrimage tourism in Serbia represents a developed, yet highly unregulated activity. Seeing as official tourist organizations, the Serbian Orthodox Church (SOC) or the state take no part in its development, it mostly takes place within the "gray zone". A lack of control over this activity leaves tour guides and organizers of pilgrimage tours with a lot of leeway in choosing the sacred places which will be visited and narratives utilized during the trips. This kind of "liberty" in (re)presentation is reflected in very uneven concepts of SOC sacred places among pilgrims, as well as in different religious practices in them. In this paper I will present the results of research conducted between 2013 and 2017 on pilgrimage tours in Serbia. The aim of the paper is to point out the most important traits of contemporary pilgrimage in Serbia - ways of organizing, the structure of pilgrim groups, the kinds of narratives used on these voyages, as well as the role and significance that pilgrimages had in the process of "spiritual growth" of traditional orthodox believers.

Key words: pilgrimage tourism, pilgrims, monasteries of the Serbian Orthodox Church, Serbia

Even though organized pilgrimage tourism has been present in Serbia for the past three decades, it is still an unexplored

1 The text is a result of the work on the project Identity strategies: contemporary culture and religiosity No. 177028, which is financed entirely by the Ministry of Science and Technological Advancement of the Republic of Serbia. 
phenomenon. ${ }^{2}$ Its roots lie, in part, in the increase of the numbers of religious people in Serbia, and in part in the national-political pilgrimages to shrines of the Serbian Orthodox Church which had a significant role in the mobilization of the populace and the awakening of the ethnic/national identity of Serbs in the late 1980's and early 1990's. Because of the double role that pilgrimages played in this period, it is difficult - even today - to view them as simply religious or spiritual voyages. This period left behind certain narratives and ideas about monasteries as "border stones of Serbian spiritual space"3 (Mileusnić 1997) and "material evidence of the long tradition and continuity of the nation" (Perica 2006, 40).4 Thus, the religious and national aspects of pilgrimages - as in public discourse - are hard to separate.

Three decades ago, when the process of building and restoration of numerous churches and monasteries of the Serbian Orthodox Church in Serbia and Former Yugoslavia began, 5 a number

2 In Serbia the term pilgrimage/religious tourism is accepted by all organizers, including official church agencies, because the term tourism in the title refers to the way of organizing and not the purpose of the trip.

3 The website of the official agency of the Serbian Orthodox Church, founded in 1990, up until recently it was written: "Through visiting Serbian monasteries and churches which are the border stones of Serbian history, 'Dobročinstvo', each year from April until October, takes you to the sources of our spiritual and national identity. Every program is an anthology, stemming from years of experience and research of culture and spirituality of the Serbian people" (Taken from the official website of "Dobročinstvo" in 2013).

${ }^{4}$ Such (re)presentation is based on the fact that monasteries of Serbian Orthodox Church contain tombs and remains of Serbian rulers from the middle ages, on the idealized relationship they had toward monasteries (such as founding monasteries, and later on, becoming monks), as well as on the significance of the role which monks and monasteries played in the advent of literacy, medicine and church art in Serbia, that they were a forerunner of museums with rich treasuries and libraries etc.

5 Since the 1990s the Serbian Orthodox Church has erected and/or restored about 500 churches and monasteries. The majority of churches are erected at the request of local believers who mostly help with the building of churches. Besides generous donations from believers, church building is funded from state funds and the funds of local communities (Spasojević and Milojević 2014, 37). 
of priests and people close to the church - as one of the most prominent organizers of pilgrimage tours from Belgrade states wished to:

“(...) bring the importance of orthodox sacred sites and spiritual healing in all sacred places closer to the people, as well as to develop a bond between the people and orthodox monasteries and monks in order to foster close contact and cooperation for the benefit of both sides. For the people to experience spiritual healing at the sacred sites, and help the monks with restoration and other needs".

After decades of atheism, the primary goal was, on the one hand, to bring monastery life, spirituality and Christian values to laypeople, and on the other hand to give financial aid to further projects of building and restoration of monasteries.

When pilgrimage tourism in Serbia first began, the organization of such voyages was the domain of the official patriarchate agency of the Serbian Orthodox Church, and its priests. In the meantime, as interest in visiting sacred places and shrines grew, the number of organizers of pilgrimage tours grew as well. Recently, aside from official agencies of the SOC (beside the patriarchate agency, a number of eparchial agencies have been founded) and priests, pilgrimage tours are organized by people close to the church who aren't ordained - representatives of associations and societies that foster orthodox or traditional values, organizers of spiritual lectures, professors or students of the Faculty of Orthodox Theology, organizations that promote and safeguard Serbian national identity, tourist bureaus that, organize pilgrimages aside from organizing ordinary tourist trips, as well as transportation firms which offer transport to sacred sites to selforganized groups without guides, and, finally, groups that organize pilgrimages on foot. Even though most of these organizers take pilgrims to sacred sites of other Orthodox churches as well, most of the voyages throughout the year are organized to monasteries of the Serbian Orthodox Church, as those are easier to organize and cheaper for the pilgrims. 
Information on current pilgrimage can be found on official websites of the organizers, on posters discretely pinned in front of parochial churches, on social networks as well as through text messages from organizers once contact has been established. Text messaging is especially popular among independent organizers who sometimes work in tourist bureaus. They have databases containing the phone numbers of pilgrims, acquaintances and other interested parties whom they inform about the pilgrimages they organize through text messages. Unlike official agencies that promote their pilgrimage tours for months in advance, independent organizers send out invitations up to ten days in advance and organize pilgrimages more frequently. These tours are organized throughout the year including weekdays, and are often connected to religious holidays or monastery slavas. ${ }^{6}$ These groups often travel in minibuses transporting up to twenty pilgrims. ${ }^{7}$ This way the pilgrims are devoid of comfort but such conditions foster integration within the group and encourage communication and sharing of experiences among members. ${ }^{8}$

6 The slava is an annual family ceremony that venerates a family's patron saint but may also be a church/monastery ceremony.

7 These are usually older models of minibuses which are less comfortable than regular buses. There's less space for sitting, which impacts older and less mobile pilgrims the most. Aside from this, there isn't enough room for the things that the pilgrims carry with them (personal items or things they wish to gift to the monasteries). Because of this, they are often forced to keep their things in their laps during most of the trip. The minibuses also often have other flaws - the AC doesn't work, there's not enough air, the microphone or the speakers don't work - so the pilgrims can't hear the guide etc. The lack of comfort is, among other things, connected to the fact that the cost of the voyage should be as low as possible (travelling by minibus is 20 to $30 \%$ more expensive than taking a bus to the same pilgrimage place), and the lack of comfort is often seen as a kind of "tribulation" or "feat" by the pilgrims, so they never complain about transportation.

8 During the research I conducted travelling with different pilgrim groups to Serbian Orthodox Church monasteries in Serbia, Montenegro, Kosovo and Metohija between 2013 and 2017, I noticed that, within the smaller pilgrim groups, communication and exchange of experiences came about more easily in the smaller groups, as opposed to the larger groups numbering between 50 and 
Even though almost three decades have passed since pilgrimage tourism was first established, this activity still lacks official, institutional support. As an institution which formally deals with and controls pilgrimage tourism doesn't exist, aside from partial information on the organizers of such voyages, little is known about this activity. In this paper I will attempt to systematize some of the basic factors of development of pilgrimage tourism, present what actual pilgrimages in Serbia entail, and demonstrate the ways in which pilgrimage destinations are chosen by the pilgrims and which narratives dominate pilgrimage voyages.

PILGRIMAgE DESTINATIONS BETWEEN RELIGIOUS AND SECULAR DISCOURSES. In the influential edited volume Contesting the Sacred. The Anthropology of Christian Pilgrimage Eade and Sallnow conclude that pilgrimage destinations are "an arena for the interplay of a variety of imported perceptions and understandings, in some cases finely differentiated from one another, in others radically polarized" (Eade and Sallnow 2013, 10). Like other pilgrimage destinations, SOC monasteries represent a space in which many religious and secular discourses intertwine. Different actors in the pilgrimage process produce representations and meanings of monasteries which are integrated through different interpretative frameworks. In this part of the paper, the focus is on two main actors - organizers or tour guides and the monks - who play the largest role in shaping the ideas of pilgrims about monasteries (in the production of ideas about monasteries other pilgrims also play a significant role).

PILGRIMAGE ORGANIZERS AND TOUR GUIDES. In most cases, organizers of pilgrimage tours are people close to the church or dedicated Orthodox Christians with many contacts within the Serbian Orthodox Church. Aside from providing transportation and

80 pilgrims. However, the degree of integration into the group is lesser among married couples and those who travel in small groups (friends, siblings...), because they are more focused on their own company than on other pilgrims. 
information to pilgrims about tours, they exercise a kind of "control" over the way pilgrims experience the monasteries and over their knowledge of faith, religious practice and life in general. Pilgrimages serve to help a number of pilgrims to obtain information on important issues of faith and religious practice. Because of this, pilgrimages represent a didactic framework in which the faithful are "nurtured" and educated in the spirit of extant and desirable values. During the trips, tour guides utilize a number of types of narratives which can be characterized as informative (when tour guides dispense basic information about a sacred site), educational (when tour guides provide information on history, art, geography, theology, ecology etc.), or propaganda (when tour guides utilize political and nationalist rhetoric to point out the vulnerability of Serbian sacred sites and/or the Serbian people to Others, especially in Former Yugoslav territories).

In the first case, when tour guides give out basic information on sacred sites and relics, and when narratives of the importance of the site in the national pantheon - or the miraculous qualities of the relics - are left out, some of the pilgrims will use this "space" and fill it with their own observations and interpretations of visiting the sacred site, as well as advice on "what we should do first when we get to the monastery" or "how to pray". ${ }^{9}$ In the other two cases,

${ }^{9}$ During one journey with a group of pilgrims from Belgrade, I met Divna, a woman in her seventies who had been going on pilgrimages for the last ten years or so. She was well acquainted with the tour guide we traveled with, as well as with most people in the group whom she knew from her parish church or from previous journeys, so she used ever opportunity to complement the guide with information about the sacred site and miraculous healings, because the guide had only provided us with basic information about the site. She walked through the bus during the trip offering information about faith, the church, national history, orthodox customs and the sacred site, probably believing that what we had heard from the guide wasn't enough. She also gave advice on what we should do first when we arrive, how we should pray, what to say, where to light a candle, how big the candle should be, what we mustn't do. Because this was her eighth visit to this specific monastery, she used her experience as social capital which enabled her easier integration and positioning within the pilgrim group. She had also used this opportunity to sell teas and medicinal salves on the bus. 
when tour guides utilize the educational or propaganda types of narration, they have a larger degree and sometimes absolute control over the discourses involved. In these cases, tour guides impose themselves as authorities that are not only attempting to inform and explain the places being visited to the pilgrims, they are trying to indoctrinate them and impose their own view of wider social processes which fit into the religious dogma in different ways. Such narratives are most present on tours of monasteries located in ethnically or religiously diverse areas, such as the Raška region in Serbia, Kosovo and Metohija, Bosnia and Herzegovina or Croatia. ${ }^{10}$ Thus, the more informed or "authoritative" the tour guide, the lesser the need - and indeed, possibility - for the pilgrims to use their own experiences and interpretations to construct the ideas about a sacred place. In this sense, we can speak of pilgrimages which foster free exchange of experiences and interpretations of institutional messages, and those which entail solely the absorption of narratives from the institutional (or quasi-institutional) level of the tour guide. Pilgrims react to messages of the second kind in various ways, because guides are not officially certified by the church, and their knowledge can be questioned.

10 For example, when passing through parts of the Former Yugoslavia inhabited by Bosnians some guides will say things like "these parts are inhabited by former Serbs and former orthodox Christians who gave up on their faith and converted to Islam"; or "If this is your first time in Raška or you weren't in a similar situation before, based on many years of moving through these areas I suggest you pray to St. Peter Koriški, the Mother of God, St. George Bringer of victory and others and there will be no trouble. It is only important that we, as orthodox Christians do not provoke the situation and don't provoke anyone with our behavior and everything will be all right"; or "to the left you will see the tomb of the holy martyr Hariton who was killed by the Šiptari during the last war 1998-9. They beheaded him...", after which there is usually a long discussion among the pilgrims about how the Serbs are threatened by other peoples, especially the neighboring ones (sometimes the anger is directed at the US or EU), wherein the focus is always on the fact that Serbs are endangered on "their own territory", wherein their territory entails any and all spaces where Serbs lived at any point in history, which "is best attested to by the material remnants of their churches and monasteries". 
With regard to the discourses they favor throughout the pilgrimage, the tour guides themselves can be divided into different groups: those who favor historical facts with clear national meanings, those who are primarily focused on the artistic side of sacred sites, and those who are focused on the spiritual aspects of the monastery which is being visited. In accordance with this, there is a difference in the degree of acceptance of the tour guides by monastery brotherhoods or sisterhoods. According to this criteria, the guides can be divided into those who are well acquainted with the monastery staff and thus get a lot of attention and their group is well received, and those who are fairly distant from the monks and nuns, and are thus received more coolly or in a "strictly professional" manner. Groups led by the latter are often bereft of meaningful information or useful informal conversations with monks. $^{11}$

Today, monks (especially elders or spiritual fathers), along with monastery grounds and holy relics, make up an important factor that attract pilgrims and pilgrimage groups. Through example, and their spiritual achievements and words, they represent role models and authorities which should be seen and obeyed. Because of this, the possibility of direct communication with clergy represents a special event which influences the overall experience of pilgrimage for the pilgrims. However, the monks and nuns have different approaches toward pilgrim groups and this

11 In accordance with this, pilgrims often gather information on who the tour guide is, even when they use the services of official agencies, so as to know what they can expect, and so they can decide whether they want to travel with a certain guide at all. Because of this it can be said that pilgrims have a certain possibility of control over the context and discourse of the journey, depending on personal traits, the characteristics of the sacred site itself, the personality of the guide, the time of the visit etc. They can have some choice in the matter when or with whom they will travel, what they will watch or listen to during the trip (they carry their own CDs), how much they will attempt to influence other pilgrims etc. Because of this, the journey is never just a passive process of accepting, but also an active process during which desired meanings are read into the sacred sites being visited. Also, the pilgrimage destination in and of itself doesn't have to be the primary reason for travel - a certain kind of experience or emotion which pilgrims wish to feel can be the reason. 
form of "tourism" - some see them as an opportunity to raise the spiritual awareness of the faithful, others utilize it to keep up folk religiosity, while a third group attempts to use their sermons to awaken or strengthen national/ethnic identity as well as religiosity, and utilize different discourses to these ends.

K., a young nun, represents the first group. A member of the younger generation of clergy, this woman retreated to a monastery after obtaining two university degrees. A refugee from Bosnia, she came to Serbia with her mother in the early 1990's, and today is very critical toward nationalist discourses and nationalism within Serbian Orthodox Church. She, being the only nun in the monastery, and a priest who comes by from the local parochial church, strive to help pilgrims and local churchgoers separate Christian from pagan religious practices:

“(..) both the Father (author's note: priest) and I often tell them how to act, we try to point out that there's no need for some things, that it isn't good to exaggerate in one's faith... a person can fall into prelest (translator's note: a kind of spiritual illness or false spiritual state in Orthodox theology). We tell them how they should treat the relics, but they won't listen. They always say this is how my mother or my grandmother did it, this helps, I heard that you shoud do this. (...) Some monasteries offer skirts and scarves, we don't do that here. We can't do the washing because people don't respect the dress code. (...) I always tell them to take something to read, to pray, to strengthen their faith. Sometimes I give them advice on how to deal with life problems, to worry less about material things..."

On the other hand, there are those monks who support elements of folk religion. Thus, all pilgrims who come to the Nikolje monastery receive "instruction" from the nuns or guides to "walk three times around the pine tree" located in the church yard, so 
their wishes will come true. ${ }^{12}$ There are numerous such examples. They stand in opposition to monasteries in which such practices are interpreted as magic and superstition. Such contradictions mostly occur because concepts of pilgrimage sites and religious practices within them aren't uniform as they are constructed based on different discourses. Since the start of the new millennium, the media and public discourse have engaged in a hyper production of stories about miracles and miraculous cures, which have since become the main trait of sacred sites in Serbia (Radulović 2012). Testimonies of miraculous events and relics can be read daily both online and in print media.

The motif of the miraculous, presented as real, personal events served as a marketing strategy for sacred places, the role of which was to foster and strengthen godliness. Even though, at first glance, these miracles have individual meanings, on a wider social scale, they are interpreted as messages directed at the "Serbian people". This interpretation mostly comes from the clergy. Mass gatherings in monastery churches and church yards are usually an opportunity to pass religious messages to the faithful, but sometimes these messages are social and political in nature as well. Recently, I listened to a priest's sermon directed at thousands of gathered followers in a monastery in Central Serbia:

"(...) this is why we have monasteries in which we have people and girls to pray to God for us every day, this is why we have Hilandar on Mount Athos, Dečani in Kosovo, and this is why we have the hermitage of Saint Sava where the Psalters are read every day. And it was said that if the Psalters were to stop being read in that hermitage, the Serbian people will disappear, and the world will come to an end. Brothers and sisters, our fate is tied to this faith; we are fatefully tied to the Mother of God and the god-man Christ. Because of this,

12 The brochure on the monastery also states that "the churchyard is home to a hundred year pine tree which the ill, led by a priest, walk around seeking salvation. It is believed that the pine heals the mentally ill and helps barren women". 
brothers and sisters, let us remember why we came here. We came to repent, to forgive each other, so the Serbian people can move forward, to pray to God and the Mother of God, to save the Serbian lands, the Serbian people, so there isn't forty thousand less of us each year, so there is more of us, so we can move forward for once. The Mother of God wants to help us, but the question is will we?! We ourselves must decide to move forward. We have role models, we have saints, we have the church, we have everything. We just have to come to Christ our God, to confess our sins and take a new path. The path of penitence. The path of forgiveness. And thus we will achieve what God wants from us..."

These words confirm Morinis' $(1992,4)$ observation that the pilgrimage destination is a place which reflects an intensive version of a collective ideal of culture.

The examples given here show that the official church still has weak power over discourses and religious practices in monasteries, which is reflected in the multiplicity of religious practices and religious "knowledge" encountered during pilgrimages. Also, many Orthodox Christians go to monasteries because they believe that praying in a certain place is more effective or because they are spurred on by nationalist discourses about monasteries as holy places of nation, wherein national identity takes supremacy over religious identity.

THE HIERARCHY OF PILGRIMAGE DESTINATIONS. The choice of pilgrimage destination depends on the motives of the pilgrims, while their motives depend on factors such as the degree of religious culture, knowledge of orthodox teachings, the degree of connection to the church as well as the expected outcome of the visit. In accordance with pilgrims' perceptions, monasteries in Serbia can be divided into a number of categories: healing (where pilgrims go believing that praying in that specific monastery will help them achieve their goals or be cured of disease); sacred sites of 
the Serbian nation - where many pilgrims go not only to bow to the sacred place, but to bow to national history and tradition (eg. Hilandar in Mount Athos); monasteries to which pilgrims are attracted by certain members of the clergy. ${ }^{13}$ If we were to construct a hierarchy based on the "popularity" of monasteries among pilgrims, it would look something like this. This hierarchy is a product of belief in the power of a sacred place, or, as James Preston (1992) called it spiritual magnetism. However, when asked directly whether they differentiate between monasteries, the pilgrims usually respond negatively and claim that the "blagodat (translator's note: grace of God) is the same everywhere". This begs the question why they visit monasteries in the first place, as well as how they differentiate between churches and monasteries. ${ }^{14}$ of around seventy pilgrims I've interviewed, only four clearly stated that they differentiate between sacred places - one man prioritized them by the importance and prominence of the relics (icons, graves and remains of saints), one woman stated that her hierarchy was based upon "personal feeling after contact with the sacred place" and the "amount of blagodat", a third man divided monasteries into old and new saying that for him personally "the new ones aren't as meaningful, they are built for generations that will come after" and that he visits monasteries built by Serbian rulers "because they are our greatest holy treasures", while a another woman said that the "blagodat is greater in older monasteries, because more prayers have been accumulated during the centuries in these places". Other respondents, even if they claim that they do not differentiate, often choose the same or similar type of monastery they visit or the same

13 Even though many SOC monasteries have different cultural, historical and artistic significance, and some of them are on the UNESCO list of cultural heritage, the pilgrims rarely pay any attention to the frescoes, architecture or other things in a church unless they've been told that it is "miraculous".

14 Many pilgrims, including churchgoers, claim that there is no difference between liturgy in a monastery and liturgy in a church, but they state that "their feeling in monasteries is more intense and that the blagodat in them is greater than in parochial churches because of the prayers to God which occur in them every day". This understanding influences the feelings and relationship of the pilgrims to monasteries and assures that it is different than their relationship to parochial churches. 
tour guide. On the other hand, there are those pilgrims who always choose tours that take them to monasteries they hadn't visited before. It is therefore clear that they wish to mark as many sacred sites in their pilgrim biographies as possible. This practice is more frequent among those pilgrims who are searching for something they are unable to find in themselves and their own faith or parochial church, so when visiting a monastery they will say things like "I've never felt peace such as this" or "this is a wellspring of true spirituality".

That there are differences between monasteries and that they are shaped by current public discourse and media marketing is evidenced by one example. In October of 2014 in the monastery Pokrov Presvete Bogorodice (eng. The Shroud of the Holy Virgin) in Djunis, the only SOC sacred place where the Mother of God was said to have appeared, which is one of the most visited sacred sites in Serbia, I conducted a survey among pilgrims who came on the day of the monastery slava, from different parts of Serbia and republics of Former Yugoslavia. Few of them knew about the Saint Roman monastery (one of the oldest monasteries in Serbia which houses the remains of Saint Roman) ${ }^{15}$ and is located merely $5 \mathrm{~km}$ from the monastery in Djunis. Those who knew about it would visit it "in passing" - because it is nearby. Most of the pilgrims learned about monastery in Djunis (which was founded in the 1960's) during the last ten years thanks to the media, pilgrimage tours and from the experiences of pilgrims who were healed in this monastery. Thus, the "power" of this sacred site spread through narration and media, spreading further from the local legend which was known as far back as the late $19 \mathrm{t}^{\mathrm{t}}$ and early $20^{\text {th }}$ centuries, when local people used the spring of holy water to cure illnesses. A similar thing occured in October 2017 when I visited this monastery with a group of about fifty pilgrims from Belgrade. We were all informed that after Djunis monastery we will be visiting the Saint Roman monastery, as well as two other monasteries in the region. Because

15 This monastery is famous because the heart of the Russian colonel Nikolaj Nikolajevič Rajevski is burried there. Rajevski had been the inspiration for Leo Tolstoy's character count Vronsky in the novel Ana Karenina. 
we were held up at Djunis, the tour guide suggested that we "do not spend too much time at St. Roman", because we would be late to liturgy at the Lešje monastery (third monastery on our pilgrimage). None of the pilgrims protested this decision, and they all stated that they couldn't wait to visit the healing relics at Lešje. I spoke to 14 women who were sitting around me on the bus and asked if they knew whose remains are housed at Lešje monastery, and most of them didn't know (one knew about two saints and another knew of one),16 but they all "heard that they help" and that "we are visiting a great holy place". Print media, internet forums and social networks play a significant role in the promotion of sacred places. Because of this, local governments and members of local communities, recognizing the economic potential, work tirelessly on promoting monasteries. I have also given this example in order to show one of the ways in which tour guides, not always on purpose, influence the construction of hierarchies of sacred sites. I'm talking about the amount of time spent in each monastery which is decided by the guides. The length of the stay usually reflects the position of the monastery with regard to other monasteries which the group visits during the pilgrimage.

This practice is further enabled by folk belief and a magical relationship toward the relics which are still present among the faithful. Even though the pilgrims have learned over the years that such behavior is not in accordance to Orthodox dogma and belief, most of them have so far managed to "Christianize" their narratives about sacred sites, but their practices are still rooted in folk religion. Thus, pilgrims in a church may be seen dipping their fingers into the oil in the cresset (kandilo), taking photos of healing relics so they can pray to them when they are not at church or touching different objects to the holy relics.

PILGRIMAGE AS A FEAT. Pilgrimage, in an ideal sense, represents a kind of feat during which spiritual growth of the pilgrim occurs.

16 The monastery houses the remains and partial remains of ten early Christian martyrs. 
During short pilgrimages which last a day or two and to not include far off destinations and don't cost too much, the feeling of accomplishment is somewhat absent. When tours are well organized, there doesn't even have to be a lot of walking involved, because for the elderly or the sick and those who have difficulty walking there are cars to take them from the bus parking space to the monastery itself. In this sense, these trips do not represent feats such as pilgrimages that took place when transportation and infrastructure around monasteries wasn't developed, or such as bathing in holy springs in winter in Russia (more about pilgrimage in Russia in: Kormina 2010, Naletova 2010). Because of this, pilgrims try to make their journeys as difficult as possible. Sometimes they do this by choosing a cheaper organizer which often entails less comfortable transportation. In this discomfort and bodily suffering (the elderly experience back pain, their legs swell up etc) pilgrims find a way to perceive the pilgrimage as a feat. Another way is to visit monasteries which are located in ethnically or religiously mixed areas, where both the guides and pilgrims go with a dose of fear and uncertainty and "with God's help". One of the tour guides remembered the first trip to Kosovo and Metohija he organized in 2003, a couple of years after the war, when a young man from the group approached him and suggested that they "take the icons and relics of the bus's windshield when they pass into Kosovo, so that they do not provoke the Albanians". For Orthodox Serbs, sacred sites in these territories aren't just religious, they are also national, because even today they serve as a reminder that Serbs used to ("until recently") live there. When they take pilgrims to these sites, organizers tend to remind them that it is a great blagodat to see these endangered sites and leave a contribution to the brotherhood/sisterhood. Almost all of my male respondents had visited monasteries in Kosovo and Metohija (these pilgrimages are rarer among women, but they are definitely present). These pilgrimages are more than religious affairs for them - they are pilgrimages to history, tradition, myths and suffering (both of individuals and the nation as a whole):

"When I stepped into Kosovo... When I stepped onto the bus for Kosovo, I felt a kind of force. I felt that unbelievable thing - the blagodat connected to 
suffering. The joy of blagodat mixed with the suffering down in Kosovo. Of all the pilgrimages I've undertaken, this one left the strongest impression on me. Kosovo!".

THE STRUCTURE OF PILGRIM GROUPS. Most pilgrim groups I have travelled with are dominated by women, which gives the impression that they go on pilgrimages more often than men. The interviews (50) I did with both men and women, however, show that the average number of pilgrimages among men and women is similar (around 10). Of course, there are those who travel a couple of times a year but also those who go on pilgrimages up to twenty times. The difference is in that men go to further destinations or longer trips more often. Thus it may occur that men go to Mount Athos and Hilandar monastery a number of times during the year. Men travel to Kosovo and Metohija, Russia and the Holy Land more often. Also, men will more often organize trips themselves, they will form groups, rent vehicles and create their own circles of pilgrims, carefully choosing the organizer, so in a way they are less visible in group pilgrimages. Interest in holy relics is also lesser among men (eg. they will rarely take objects from their loved ones and touch them to holy relics), and they are more interested in the history of sacred sites and their national importance.

Regardless of gender, pilgrimage tours attract a large number of people who are familiar with the church's teachings - liturgy, fasting, prayer, mostly they fast during all the fasts, they confess and take communion. A group will almost always have new pilgrims, those who had just "awakened" and who use these journeys to get close to Orthodox teachings or experience a spiritual transformation. New pilgrims are always most interested in the narrative offered by the tour guides, other pilgrims and clergy. Their ideas about monasteries and their relationship toward religious practice is shaped by these narratives.

A large number of pilgrims undertakes these trips alone. The reason for this is that in many families in Serbia one member was converted into a churchgoer, while other members remained atheists or traditionally religious. Regardless of the high number of 
self-declared Orthodox Christians in Serbia (over $70 \%$ of the populace), churchgoers number less than one percent. ${ }^{17}$ Orthodox Christians who regularly go to church, fast, pray and confess often feel stigmatized in the larger community, and their familiarity with church doctrine is viewed as "straying into faith", or as "over the top", "pathological", "fanatic" or a "sectarian" turn toward the church (Simić 2005). Pilgrimage tour groups afford a higher degree of understanding and acceptance to these people than their normal surroundings do. In these groups, prayer or the belief in the power of holy relics is not viewed as primitive behavior. A number of pilgrims I spoke to had similar stories about how people close to them didn't understand or accept them. Milena (1973) converted to the church and pilgrimage some ten years ago after the demise of a long relationship, because her fiancé thought that "she became too attached to the church". Biljana (1975) started going on these pilgrimages in order to meet religious people, because there aren't any among her family, friends and work colleagues. She says she started going on these pilgrimages because it was "the easiest thing to do". As she told me -

"When I started visiting monasteries regularly, a sort of change occurred. At first, my friends teased me because of this, but when they saw that it was genuine and that my interest in faith kept growing, they started abandoning me using different excuses. None of this threatened them in any way, I did not try to persuade them to convert to orthodoxy... it's just that I lost interest in partying, inebriation and vulgarity. Sometimes when I would invite them to go to a monastery, they'd come but it turned into a kind of day trip which included other tourist attractions, lakes, restaurants and such, which I didn't like. On the other hand, I figured out that these group trips are the easiest

17 Precise statistic data on the number of churchgoers in Serbia do not exist. This piece of information became the most often given answer among the faithful and the clergy of parish churches I have spoken to. This is a number one gets by considering the number of those present at liturgies as opposed to the number of people who live in the parish. 
for me, and they are cheaper than if I were to take my own car. Here I meet people to whom I don't have to explain why I believe in something or convince that God exists... and besides, I can learn things from them. This exchange of experiences really helped me at first, when I didn't know anything, and didn't even go to church. They especially helped me to figure out which monasteries I should visit".

Her story shows that other pilgrims and their experiences really do play a part in the promoting of certain sacred sites.

ThE TRANSFORMATIVE POTENTIAL OF PILGRIMAGES. Pilgrimage can have a transformative potential for those who are otherwise not connected to the church, and who acquire their first knowledge about faith through these voyages, at first from tour guides and other pilgrims and then from clergy. These trips are an opportunity to get an informal religious education in interaction with a wider religious community. For many who grew up in socialism and in atheist families, their first contact with religion, doctrine and the sacred occurred on trips such as these. Even though they lack formal control and oversight and have certain economic goals, these voyages are also a kind of evangelism. The posters and flyers that are left in public spaces - on bus stops, street lights, at cultural centers, near churches etc. galvanize people with fuzzy ideas about religion who will more easily decide to visit a monastery than to go to the local church. I have met a number of people who are uninterested in the religious aspect of these trips - they equate pilgrimage tourism with cultural tourism which enables them to learn about Serbian history, but after some time they will spontaneously approach faith and begin taking part in religious ceremony. I had met women who came with too much make up or inadequately dressed, and who, after some time and warnings (or friendly advice) from guides or monks began following regulations. Because of such examples, I believe that pilgrimage tours, even with the differences in narrative or organization, had a certain role in attracting people to the church and "spiritual awakening" of religious people in Serbia who are devoted to traditional orthodoxy. 
Whichever narrative aside from the religious the organizers used the aim was always the same - laying the spiritual groundwork which would change the type of religiosity of a number of people. Also, pilgrimage tourism created a framework through which people who are in the process of conversion from traditional to church orthodoxy can get to know the purpose and meaning of the orthodox faith. These pilgrimages afford many an opportunity to be integrated into a society of faithful and assess how far their further spiritual development can go. For those who regularly go to church, pilgrimage tours offer an alternative to classic tourism practiced by most, while for those who normally don't go, pilgrimages represent a phase during which they will slowly get acquainted with orthodox teachings and practice.

RETURNING HOME - THE OTHER SIDE OF THE PILGRIMAGE. The relationship between tourism and pilgrimage was a topic of discussion in a number of papers over the last few decades (Cohen 1992; Badone/Roseman 2004; Timothy/Olsen 2006; Swatos 2006; Strausberg 2011). Unfortunately, anthropologists in Serbia have not dealt with this topic, while researchers from other disciplines insisted on clear divisions between tourism and pilgrimage (ex. Nikolić 2010), or rather, on interpreting the reasons for pilgrimage as being entirely of a religious nature. 18

18 During my fieldwork, I had often encountered people who had started going on pilgrimages in order to visit monasteries as "parts of our or global cultural heritage" or to "keep company" to a friend or family member. An example of this is a married couple whom I had encountered on different pilgrimage trips for years. At one point they explained their desire to visit monasteries by travelling specifically with pilgrim agencies: "We spent a lot of time travelling around Greece, and they have great monasteries. We would go on vacation and then make a field trip to a church or monastery. First we went to see Meteora, and one years my husband and my older son went to Mount Athos. After some years we realized that we haven't gone to see our monasteries at all, even though we went abroad to see others'. We started searching on the internet, and saw that "Dobročinstvo" (author's note: the official agency of the Serbian Orthodox Church) organizes visits to monasteries and that's how we started. By now we've been to many places... This is a way for us to learn more about monasteries, and we hear a lot of wise words and 
When viewed from the sidelines, it is hard to draw a definitive line between a pilgrim and a tourist, even when the reasons for travel are solely internal or religious. This is best demonstrated while the pilgrims are on the bus during the trip back. It is then that they begin to relax; they tell stories and anecdotes from their trips, or about their everyday lives, unburdened by religious discourses. They often insist on taking breaks and having coffee together, whence they discuss many different things - from everyday stuff to larger political issues. Sometimes, during this last leg of the pilgrimage, a kind of communion occurs between the pilgrims - in the sense that, regardless of differences in their initial motivation for undertaking the journey or the extent of their religiosity, in the end they all act as if they had fulfilled a common goal.

Another conspicuous occurrence is the summation of impressions on the way back - and the unwritten rule says that these impressions must be positive. Over the last few years, even though I had witnessed many oversights and lapses in organization, bad tour guiding, the disapproval or dissatisfaction of pilgrims due to the changes in travel plans, not following the timetable or a cool reception of the group by the clergy, I have never heard negative comments expressed on the way back. The impressions are always positive and the journey is always discussed in a positive light. In order to facilitate a good mood on the bus, tour guides will usually interpret any negative occurrences as "the great temptations which were put in our way in order to strengthen our faith". Sometimes they will go so far as to assure the pilgrims that the more challenging the journey, the greater the sacred place they visited. When faced with dissatisfied pilgrims, some tour guides will say "forgive...", inviting the pilgrim to react to any kind of problem or issue in a Christian manner.

CONCLUSION. In this paper I have offered a classification, systematization and description of the basic elements which make

advice for our everyday lives from the monks who welcome us. This doesn't happen when travelling with the usual travel agencies". 
up pilgrimage journeys. Even through the paper is rife with generalizations and "most case scenarios", it does not undermine the value of personal experiences and impressions during contact with pilgrimage destinations, rather it strives to view them in light of the appropriate social and political contexts.

Unlike other Orthodox countries (Russia, Greece, Romania) whose sacred sites are recognized and visited by all orthodox Christians, pilgrimage tourism in Serbia is, for now, "closed type" mostly intended for Orthodox Serbs, and to foster their spiritual growth and churchgoing habits. Seeing as the sacred sites of the Serbian Orthodox Church do not attract foreigners to the extent that they do in other orthodox countries, all the actors of the pilgrimage ritual (the organizers, clergy, pilgrims...), when interpreting the meaning and significance of the pilgrimage have trouble dividing the religious from the national aspects of it. These aspects are still strongly intertwined, as are folk belief, magic and religion. Today, pilgrimage voyages are organized along the thin line between tourism and spirituality, representing a new space of social interaction and a framework for (re)constructing the religious and national identity of the pilgrims.

\section{References}

Badone, Ellen and Sharon R. Roseman, eds. 2004. Intersecting Journeys: The Anthropology of Pilgrimage and Tourism. Urbana and Chicago: University of Illinois Press.

Cohen, Erik. 1992. "Pilgrimage and Tourism: Convergence and Divergence." In Sacred Journeys. The Anthropology of Pilgrimage, ed. A.Morinis, 47-61. Westport: Greenwood Press.

Coleman, Simon and John Eade, eds. 2004. Reframing Pilgrimage. Cultures in Motion. London-New York: Routledge.

Eade, John and Michael Sallnow. 2013 [1991]. "Introduction." In Contesting the Sacred. The Anthropology of Christian Pilgrimage, ed. John Eade and Michael Sallnow, 1-29. Eugene, Oregon: Wipf\&Stock. 
Kormina, Jeanne. 2009. "Avtobusniki. Russian Orthodox Pilgrims' Longing for Authenticity". In Eastern Christianity in Anthropological Perspective, eds. Chris Hann and Hermann Goltz, 267-286. Berkeley: University of California Press.

Mileusnić, Slobodan, prir. 1993. Azbučnik Srpske pravoslavne crkve po Radoslavu Gruiću [The alphabet of the Serbian Orthodox Church by Radoslav Gruic]. Beograd: Muzej SPC - BIGZ.

Morinis, Alan, eds. 1992. "Introduction". In Sacred Journeys. The Anthropology of pilgrimage, ed. A. Morinis, 1-28. Westport: Greenwood Press.

Naletova, Inna. 2009. "Pilgrimage as Kenotic Communities beyond the Walls of the Church". In Eastern Christianity in Anthropological Perspective, eds. Chris Hann and Hermann Goltz, 240-266. Berkeley: University of California Press.

Nikolić, Vesna. 2010. Verski turizam i Srpska pravoslavna crkva. Doktorska disertacija. Univerzitet Singidunum.

Perica, Vjekoslav. 2006. Balkanski idoli II [Balkan Idols II]. Beograd: Biblioteka XX vek.

Preston, James. 1992. "Spiritual Magnetism: An Organizing Principle for the Study of Pilgrimage." In Sacred Journeys. The Anthropology of pilgrimage, ed. A.Morinis, 31-46. Westport: Greenwood Press.

Radulović, Lidija. 2012. „(Hiper)produkcija čuda i čudesnih dela: značenja narodnih i crkvenih interpretacija i njihov značaj za proces desekularizacije u Srbiji" [The (Hyper)Production of Miracles and Miraculous Acts: The Meaning of Folk and Church Interpretations of these Phenomena and their Importance for the Process of Desecularization in Serbia]. Etnoantropološki problemi 7(4): 919 - 933.

Simić, Žikica. 2005. „Religijska kultura tradicionalnih pravoslavnih vernika" [Religious culture of traditional Orthodox believers]. Teme XXIX (1-2): 55-76. 
Spasojević, Milan i Milica Milojević. 2014. "New churches in the cities of Serbia and site selection for their construction." Prace Geograficzn 137: 37-49.

Strausberg, Michael. 2011. Religion and Tourism: Crossroads, Destinations and Encounters. London and New York: Routledge.

Swatos, William. H., ed. 2006. On the Road to Being There: Studies in Pilgrimage and Turism in Late Modernity. Boston: Brill Leiden.

Timothy, Dallen and Daniel Olsen, eds. 2006. Tourism, Religion and Spiritual Journeys. London and New York: Routledge. 



\section{LIST OF CONTRIBUTORS}

\section{Aleksandar Krel, Institute of Ethnography SASA - Belgrade (Serbia)}

aleksandar. krel @ei.sanu.ac.rs

Aleksandar Krel was born in Belgrade in 1968. He graduated and obtained his MA and PhD degrees at Belgrade University, Faculty of Philosophy, Department of Ethnology and Anthropology. He worked as a curator-ethnologist at the Novi Sad City Museum (1998-1999) and at the Ethnographic Museum of Belgrade (20012003). Since 2003, he has been employed at the Institute of Ethnography of the Serbian Academy of Sciences and Arts. He is the author of two monographs - Children's Games (2005) and We are Germans (2014), as well as a number of academic articles published in national and international academic publications. He has participated at a number of conferences in Serbia and abroad. He is currently engaged on the 'Multiethnicity, Multiculturality, Migrations - Contemporary Processes project (number 177027), financed by the Ministry of Education and Science of the Republic of Serbia. The subjects of his research interest are issues regarding childhood, children's games, ethnic identity and culture of national minorities in Serbia. At the moment she is engaged in two projects: Multiethnicity, multiculturalism, migrations - contemporary processes and Interdisciplinary research of Serbian cultural and linguistic heritage. Creation of multimedial Internet portal "The Lexicon of Serbian Culture".

\section{Biljana Anđelković, Institute of Ethnography SASA - Belgrade (Serbia)}

biljana.andjelkovic@ei.sanu.ac.rs

Biljana Anđelković is a $\mathrm{PhD}$ candidate in the Department of Ethnology and Anthropology at the Faculty of Philosophy in Belgrade, where she earned her BA and MA. She worked as a researcher on several domestic and international research projects on guest workers, ethnic minorities and health risks in different 
populations. Her fields of interest are: anthropology of religion, anthropology of pilgrimage, anthropology of prisons and research of identity and cultural heritage. She is employed as a research assistant on the Identity strategies: Contemporary Culture and Religiosity project at the Ethnographic Institute of SASA.

\section{Djordjina Trubarac Matić, Institute of Ethnography SASA - Belgrade (Serbia)}

djordjina.trubarac@ei.sanu.ac.rs

Djordjina Trubarac Matić was born in 1972 in Belgrade, Serbia. She graduated in 1998 from the Faculty of Philology (University of Belgrade) at the Department of Iberian Studies. In the same year she started her postgraduate studies at the Complutense University, Madrid, where she received her PhD degree in 2009. The main fields of her interest are comparative study of European traditional poetry, oral and ritual folklore and various kinds of traditional notions, beliefs and religious, mythological, social and other cultural concepts. Depending on the particular object of research, she approaches them through comparative, structural, semantic, pragmatic and semiotic analysis and interpretation. Since 2013, she has been engaged in the Ethnographic Institute of SASA on the project of Interdisciplinary research of Serbian cultural and linguistic heritage. Creation of multimedial Internet portal "The Lexicon of Serbian Culture".

\section{Ines Prica, Institute of Ethnology and Folklore Research - Zagreb (Croatia)}

ines@ief.hr

Ines Prica is a research adviser at the Institute of Ethnology and Folklore Research (Zagreb) and its director from 2015-2019. Her main fields of interests are: cultural and anthropological theory, anthropology of (post)socialism, anthropology of Europe, anthropology of work, popular culture, etc. She was the leader of the program "Culture in Transition: Hybridity, Representations, Living Practices" (2002-2006), the leader of the project "Ethnography of Worldly Transition: Templates and Deviations"(2002-2006) and 
"Post-socialism and the Cultural Subject: Hybrid Practices of Cultural Mediation" (2007-2013). As a researcher she is contributing to the project HORIZON 2020 "Closing the Gap Between Formal and Informal Institutions in the Balkans" (20162019), and the project "TRANSWORK: Transformations of Work in Post-transitional Croatia" (2017-2020). Beside numerous articles she published and coedited eight books: the monographs Potkultura: značenje stila (Subculture: the Meaning of the Style), Beograd 1991; and Mala europska etnologija (Small European ethnology), Zagreb 2001; and the edited volumes Fear, Death and Resistance. An Ethnographv of War. Croatia 1991-1992. (\& Lada Čale Feldman, Reana Senjković, Zagreb 1993); Devijacije i promašaji. Etnografija domaćeg socijalizma (Deviations and Distortions: the Ethnography of Domestic Socialism, \& Lada Čale Feldman, Zagreb 2006); Split i drugi: kulturnoantropološki i kulturnostudijski prilozi (Split and its Other: Cultural-anthropological contributions, \& Škokić Tea, Zagreb 2007); Destinacije čežnje, lokacije samoće: Uvidi u kulturu i razvojne mogućnosti hrvatskih otoka (Destinations of Desire, Locations of Solitude: Insights in the Culture and Development of Croatian Islands, \& Jelavić, Željka, Zagreb 2009); Mitski zbornik (Mythical Volume, \& Suzana Marjanić, Zagreb 2010) and Horror, porno, ennui: kulturne prakse postsocijalizma (Horror, porno, ennui: Cultural Practices of Post-socialism, \& Tea Škokić, Zagreb 2011). She (co)organized numerous regional and international conferences, among others the $15^{\text {th }}$ Conference of the Performance Studies International, "Misfiring, Misfitting, Misreading" (2009. Zagreb). She has taught anthropological theory at the Faculty of Philosophy of the University of Zagreb.

\section{Ivan Đorđević, Institute of Ethnography SASA - Belgrade (Serbia)}

ivan.djordjevic@ei.sanu.ac.rs

Ivan Đorđević Ph.D. (born in Belgrade, 1977) is a Research Associate at the Institute of Ethnography, SASA. He graduated (2003), and obtained M.Phil. (2008) and PhD (2014) from the Faculty of Philosophy in Belgrade, Department of Ethnology and Anthropology. He has been employed at the Institute of 
Ethnography SASA since 2005, where he obtained the Research Associate title in 2015. He participated in the realization of three basic research projects of the Institute, and has been engaged within the Cultural Heritage and Identity project since 2011. Up to now, he has been a part of three international research projects (interacademia cooperation projects between the Ethnographical Institute and partner institutions from Slovenia and Bulgaria). Ivan Đorđević has published three books, one of which was designated as a monograph of exceptional national importance. He published scientific studies, expert critiques and reviews in both national and international scientific periodicals and paper-collections, and is a member of the Serbian Ethnological and Anthropological Society. He actively participated in many national and international conferences and scientific meetings. He is a regular associate and lecturer at SC Petnica, and gave lectures at universities, both at home and abroad. His research interests and activities are directed towards the issues of anthropology of sports, political anthropology, anthropology of marginalized groups and anthropology of literature. Since 2016 he has been a member of the editorial board of the Bulletin of the Institute of Ethnography SASA. As a result of his research on the anthropology of sports he published a book titled An anthropologist among the football fans, which won the award for the best book in the field of anthropology in 2014 and 2015 by the Institute of Ethnography SASA. He was a Principal Investigator on the research project Research on child marriage in the Roma population in Serbia, led by UNICEF and the Institute of Ethnography SASA in 2017, and Principal Investigator on the research project Gender Gaps among Marginalized Roma in Serbia, led by Institute of Ethnography SASA in 2018, funded by the World Bank.

\section{Jadranka Đorđević Crnobrnja, Institute of Ethnography SASA - Belgrade (Serbia)}

jadranka.djordjevic@ei.sanu.ac.rs

Jadranka Đorđević Crnobrnja has been employed at the Institute of Ethnography SASA since 1999, and she holds the title of senior research associate. At the moment she is engaged in two projects: Multiethnicity, multiculturalism, migrations - contemporary 
processes and Interdisciplinary research of Serbian cultural and linguistic heritage. Creation of multimedial Internet portal "The Lexicon of Serbian Culture". Since 2016, she manages the international cooperation between the Ethnographic Institute SASA and the "Marko Cepenkov" Folklore Institute from Skopje, Macedonia. Jadranka Đorđević Crnobrnja's main areas of interest are issues of minority communities in Serbia and migrations, ethnic identity of Serbs in Slovenia, legal ethnology and anthropology and family relations in Serbia. She is a member of the editorial board of Etnološke i antrpološke sveske (journal published by the Ethnological and Anthropological Society of Serbia) and Antropologija (journal published by the Institute of Ethnology and Anthropology, University of Belgrade - Faculty of Philosophy). She is an international board member of Slovenika - Journal for Culture, Science and Education, published by the National council of the Slovenian minority in Serbia. Jadranka Đorđević Crnobrnja is a member of the International association of Southeast European Antrhropology (InASEA).

\section{Katerina Petrovska-Kuzmanova, Institute of Folklore "Marko Cepenkov", University St. Cyril and Methodius, Skopje (Republic of North Macedonia)}

kpkuzmanov@yahoo.com

Katerina Petrovska-Kuzmanova is a research advisor at the Institute of Folklore "Marko Cepenkov" at the University St. Cyril and Methodius in Skopje, Macedonia. She works in the field of folklore and literary studies, as well as in fields of ethnoteatrology (she established this discipline in Macedonia), performance and culture studies. She has published widely at home and abroad. Since 2009 she has been the editor of the international journal Macedonian Folklore. She is a professor of postgraduate and doctoral studies in Folkloristics at the University St. Cyril and Methodius in Skopje in the courses: Folklore and visual arts, Ritual folklore, Performance in folklore, Folklore festival and ethnotourism, Folklore and popular culture, Ethnoteatrology, Interpretative Folklore, and Folklore and tourism. She has authored several books: Ritual Theatre, Magor , Skopje, 2002; 2004; Ritual 
and Drama, Maska, Skopje, 2006, Theatrical elements in folklore, Institute of folklore "Marko Cepenkov", Skopje, 2006, The Carnivals In Macedonia, Institute of folklore "Marko Cepenkov", Skopje, 2009, Theater studies, Maska, Skopje, 2012.

\section{Ljiljana Gavrilović, Institute of Ethnography SASA - Belgrade (Serbia)}

ljiljana.gavrilovic@ei.sanu.ac.rs

Ljiljana Gavrilović (1953), anthropologist, Principal Research Fellow at the Institute of Ethnography of the Serbian Academy of Sciences and Arts. Fields of research: customary law, material culture, ethnographic museology and heritology, science fiction, virtual/digital worlds and digital culture as a whole.

\section{Milan Tomašević, Institute of Ethnography SASA - Belgrade (Serbia)}

milan.tomasevic@ei.sanu.ac.rs

Milan Tomasevic was born in Zemun (Belgrade) in 1983. He graduated in 2010, received his MA in 2012, and received his $\mathrm{PhD}$ in 2019, from the Faculty of Philosophy in Belgrade, at the Department of Ethnology and Anthropology. In 2015 he became a research assistant at the Institute of Ethnography SASA. His interests include science, religion and popular culture. Within these fields he has published papers in international and local journals.

\section{Petko Hristov, Institute of Ethnology and Folklore Research with Ethnographic Museum, Bulgarian Academy of Sciences, Sofia (Bulgaria)}

hristov_p@yahoo.com

Petko Hristov is a PhD in Ethnology, and Associate Professor at the Institute of Ethnology and Folklore Research at the Ethnographic Museum of the Bulgarian Academy of Sciences. Over the past few years, his main scholarly interests involve studying labour migrations on the Balkans; the construction of social networks among trans-border migrants; family and kinship; 
political anthropology. He has been the director of the IEFSEM at BAS since 2014. Petko Hristov has authored the book Community and Celebrations. The Sluzba, Slava, Sabor and Kourban in South Slavic Villages in the First Half of 20 Century, Sofia: Ethnographic Institute with Museum, 2004, awarded for best academic achievement in Humanities from the Union of Bulgarian Scientists in 2007. He is the editor of the collections Migration and Identity: Historical, Cultural and Linguistic Dimensions of Mobility in the Balkans, Sofia: Paradigma, 2012, and Balkan Migration Culture: historical and contemporary cases from Bulgaria and Macedonia, Sofia: Ethnographic Institute with Museum, 2010, and co-editor of the books: Kurban in the Balkans, Belgrade: Institute for Balkan Studies, 2007 (co-authorship with Biljana Sikimić), Labour Migrations in the Balkans, München-Berlin: Verlag Otto Sagner, 2012 (co-authorship with Biljana Sikimić and Biljana Golubović) and Contextualizing Changes: Migration, Shifting Borders and New Identities in Eastern Europe, Sofia: Paradigma, 2015 (co-authorship with Anelia Kassabova, Evgenia Troeva and Dagnoslaw Demski). Petko Hristov has published over 130 articles in a number of international journals and collections in renowned scholarly series.

\section{Vesna Petreska, Institute of Folklore "Marko Cepenkov" - University "Ss. Cyril and Methodius", Skopje (Republic of North Macedonia)}

vesnapetreska@hotmail.com

Vesna Petreska was born in 1965 in Skopje. She has been employed at the Institute of Folklore "Marko Cepenkov" since 1990. From 2001 to 2009 she was engaged as a lecturer at the postgraduate program of Ethnology of the Macedonians at Faculty of Natural Sciences and Mathematics. Her areas of interest are folk religion, rituals, beliefs and customs, the anthropology of kinship, traditional and contemporary folk culture. 


\section{Prospects for Anthropological Research in South-East Europe}

Publisher: : N. N. Miklouho-Maklay Institute of Ethnology and Anthropology, Russian Academy of Sciences, Moscow, Russia Institute of Ethnography of the Serbian Academy of Sciences and Arts, Belgrade, Serbia

\section{Approved for publication}

By the Academic Council of the IEA RAS held on April 30th 2019 and accepted as volume no. 33 at the second meeting of the Editorial board of monographs EI SASA held on May 16th 2019

Cover design: Photography by Aleksandar Kelić

Proofreading by Sonja Žakula

Подписано к печати 20.06.2019 Формат 70 х 108/16 Усл.печ. 11,3

Тираж 500 экз. Заказ № 159

Участок множительной техники Института этнологии и антропологии им. Н.Н. Миклухо-Маклая РАН 119991 Москва, Ленинский проспект, 32-А 